\title{
Review Article \\ Essential Magnesium Alloys Binary Phase Diagrams and Their Thermochemical Data
}

\author{
Mohammad Mezbahul-Islam, Ahmad Omar Mostafa, and Mamoun Medraj \\ Department of Mechanical Engineering, Concordia University, 1455 de Maisonneuve Boulevard West, \\ Montreal, QC, Canada H3G 1 M8 \\ Correspondence should be addressed to Mamoun Medraj; mmedraj@encs.concordia.ca
}

Received 30 November 2013; Revised 19 January 2014; Accepted 22 January 2014; Published 30 April 2014

Academic Editor: Alok Singh

Copyright (c) 2014 Mohammad Mezbahul-Islam et al. This is an open access article distributed under the Creative Commons Attribution License, which permits unrestricted use, distribution, and reproduction in any medium, provided the original work is properly cited.

\begin{abstract}
Magnesium-based alloys are becoming a major industrial material for structural applications because of their potential weight saving characteristics. All the commercial Mg alloys like AZ, AM, AE, EZ, ZK, and so forth series are multicomponent and hence it is important to understand the phase relations of the alloying elements with $\mathrm{Mg}$. In this work, eleven essential Mg-based binary systems including $\mathrm{Mg}-\mathrm{Al} / \mathrm{Zn} / \mathrm{Mn} / \mathrm{Ca} / \mathrm{Sr} / \mathrm{Y} / \mathrm{Ni} / \mathrm{Ce} / \mathrm{Nd} / \mathrm{Cu} / \mathrm{Sn}$ have been reviewed. Each of these systems has been discussed critically on the aspects of phase diagram and thermodynamic properties. All the available experimental data has been summarized and critically assessed to provide detailed understanding of the systems. The phase diagrams are calculated based on the most up-todate optimized parameters. The thermodynamic model parameters for all the systems except $\mathrm{Mg}$-Nd have been summarized in tables. The crystallographic information of the intermetallic compounds of different binary systems is provided. Also, the heat of formation of the intermetallic compounds obtained from experimental, first principle calculations and CALPHAD optimizations are provided. In addition, reoptimization of the $\mathrm{Mg}$-Y system has been done in this work since new experimental data showed wider solubility of the intermetallic compounds.
\end{abstract}

\section{Introduction}

Magnesium is the eighth most abundant metal in the earth outer surface at approximately $2.5 \%$ of its composition. It is an alkaline earth element (Group II) that crystallizes in a hexagonal structure (hcp-A3). Magnesium is the lightest metallic material used for structural applications with a density of $1.738 \mathrm{~g} / \mathrm{cm}^{3}$ in comparison with the densities of $\mathrm{Al}$ $\left(2.70 \mathrm{~g} / \mathrm{cm}^{3}\right)$ and $\mathrm{Fe}\left(7.86 \mathrm{~g} / \mathrm{cm}^{3}\right)$. Magnesium alloys have an excellent combination of properties which includes excellent strength-to-weight ratio, good fatigue and impact strengths, and relatively large thermal and electrical conductivities [1-3] and excellent biocompatibility $[4,5]$. This makes magnesium alloys one of the most promising light-weight materials for automotive [6], aerospace, consumer electronic (computer, camera, and cell phone), and biomedical applications due to its biodegradability. It is being used in the automotive industries in steering column parts, shift actuators, valve covers and housings, brackets, and intake manifold blades
[7]. In nonautomotive applications, small magnesium die cast components are appearing in small engines, electronic devices, power tools, and medical equipment, such as portable oxygen pumps [7]. Recently, Mg-rich $\mathrm{Mg}-\mathrm{Ca}-\mathrm{Zn}$ biocompatible metallic glass having small amounts of $\mathrm{Ca}(0-$ 8 at.\%) has been found to be suitable for the development of biodegradable implants $[4,5]$.

Some of the most common commercial $\mathrm{Mg}$ alloys are $\mathrm{AZ}$ series ( $\mathrm{Mg}-\mathrm{Al}-\mathrm{Zn}), \mathrm{AM}$ series $(\mathrm{Mg}-\mathrm{Al}-\mathrm{Mn}), \mathrm{AE}$ series $(\mathrm{Mg}$ Al-RE), EZ series (Mg-RE-Zn), ZK series (Mg-Zn-Zr), WE series (Mg-RE-Zr), AX or AXJ series (Mg-Al-Ca), and AJ series (Mg-Al-Sr) [8, 9]. For automotive applications, alloys of $\mathrm{AM}$ and $\mathrm{AZ}$ series are mainly used. AZ91D is the most widely used magnesium die-casting alloy. It has good combination of room-temperature strength and ductility, good salt-spray corrosion resistance, and excellent die-castability, compared to other $\mathrm{Mg}$ alloys.

It can be seen that most of the commercial alloys are multicomponent. The impact of each of the alloying element 
TABLE 1: Effect of major alloying elements on Mg alloys [23].

\begin{tabular}{ll}
\hline Alloying element & Effects of Addition \\
\hline $\mathrm{Al}$ & $\begin{array}{l}\text { Increases hardness, strength, and castability while only increasing density minimally. } \\
\text { Improves thermal and mechanical properties as well as assists in grain refinement and creep } \\
\text { resistance. Also, it reduces surface tension. }\end{array}$ \\
$\mathrm{Ce}$ & $\begin{array}{l}\text { Improves corrosion resistance. Also, it increases plastic deformation capability, magnesium } \\
\text { elongation, and work hardening rates. But it reduces yield strength. }\end{array}$ \\
$\mathrm{Cu}$ & Assists in increasing both room and high temperature strength. \\
$\mathrm{Mn}$ & Increases saltwater corrosion resistance within some aluminum containing alloys. \\
$\mathrm{Ni}$ & Increases both yield and ultimate strength at room temperature. \\
$\mathrm{Nd}$ & Negatively impacts ductility and corrosion resistance. \\
$\mathrm{Sr}$ & Improves material strength. \\
$\mathrm{Sn}$ & Used in conjunction with other elements to enhance creep performance. \\
$\mathrm{Y}$ & When used with aluminum it improves ductility and reduces tendency to crack during processing. \\
& Enhances high temperature strength and creep performance when combined with other rare earth \\
$\mathrm{Zn}$ & metals. \\
& Increases the alloys fluidity in casting. \\
& When added to magnesium alloys with nickel and iron impurities, it can improve corrosion \\
& resistance. \\
Additions of 2 wt.\% or greater tend to be prone to hot cracking.
\end{tabular}

is different and is needed to be understood. Table 1 provided by International Magnesium Association [23] shows a number of commonly used alloying elements alongside their effects upon the resulting alloy. Many alloying elements can be useful in a variety of different applications, whereas others are only ideal for very specific applications due to the change in properties.

In order to define the processing conditions for making various $\mathrm{Mg}$-based alloys and subsequent treatments to obtain the optimum mechanical properties, knowledge of the phase diagram and thermodynamic properties of these alloys is essential. In addition, phase relations and phase stability under given conditions can be better understood through computational thermodynamic modeling. Precise description of the binary systems provides an opportunity to approach the phase equilibria aspects of alloy development and track of individual alloys during heat treatment or solidification by calculating the phase distributions and compositions.

Several researchers including the research group of the current authors [22, 32, 41-57] have been contributing to the development of thermodynamic multicomponent databases of $\mathrm{Mg}$ alloys. However, urgency was felt for an open access publication that contains the latest understandings of all the important Mg-based binary systems. This will provide the necessary information required for further assessment of these systems. Generally review papers on thermodynamic modeling do not contain some of the critical information like previous experimental data points and optimized model parameters. Sometimes it becomes very difficult to gather this information as some of the literature is very old and scattered in many different articles and not everyone has access to them. However these are crucial facts for the regeneration of phase diagram and other thermodynamic properties. Thus the main objective of this paper is to provide all the necessary information of essential Mg binary systems in one place. In addition, brief but critical discussion of the previous experimental works on the phase diagrams as well as thermodynamic properties is provided to justify the latest understanding of this phase diagram.

This review paper focuses on some of the most important commercial $\mathrm{Mg}$-based binary systems including $\mathrm{Mg}$ $\mathrm{Al} / \mathrm{Zn} / \mathrm{Mn} / \mathrm{Ca} / \mathrm{Sr} / \mathrm{Y} / \mathrm{Ni} / \mathrm{Ce} / \mathrm{Nd} / \mathrm{Cu} / \mathrm{Sn}$. Each of these systems has been discussed critically on the aspects of phase diagram and thermodynamic properties. The latest phase diagram information along with the optimized thermodynamic parameters is provided. Also, the crystallographic information of the intermetallic compounds in each system is summarized. All these binary systems have been optimized using most up-to-date experimental information. Each of the phases in any binary system has been assessed critically and based on the thermodynamic properties; proper thermodynamic model has been used. For example, the modified quasichemical model (MQM) [79] has been used to describe the liquid phase as this is the only scientific model that accounts for the presence of short range ordering, whereas sublattice modeling with in the compound energy formalism (CEF) [80] has been used to reproduce the homogeneity ranges of the intermetallic compounds.

\section{Mg-Al (Magnesium-Aluminium)}

This is the most important Mg binary phase diagram because $\mathrm{Al}$ is added to $\mathrm{mg}$ in most of the commercial types of Mg alloys. Several researchers [81-95] studied the liquidus, solidus, and solvus lines of the Mg-Al system. Murray [95] reviewed the $\mathrm{Mg}-\mathrm{Al}$ system and his article provides a comprehensive discussion of the experimental results obtained by previous researchers. According to Murray [95] the assessed $\mathrm{Mg}$-Al phase diagram consists of liquid, $\beta$-solid solution with 


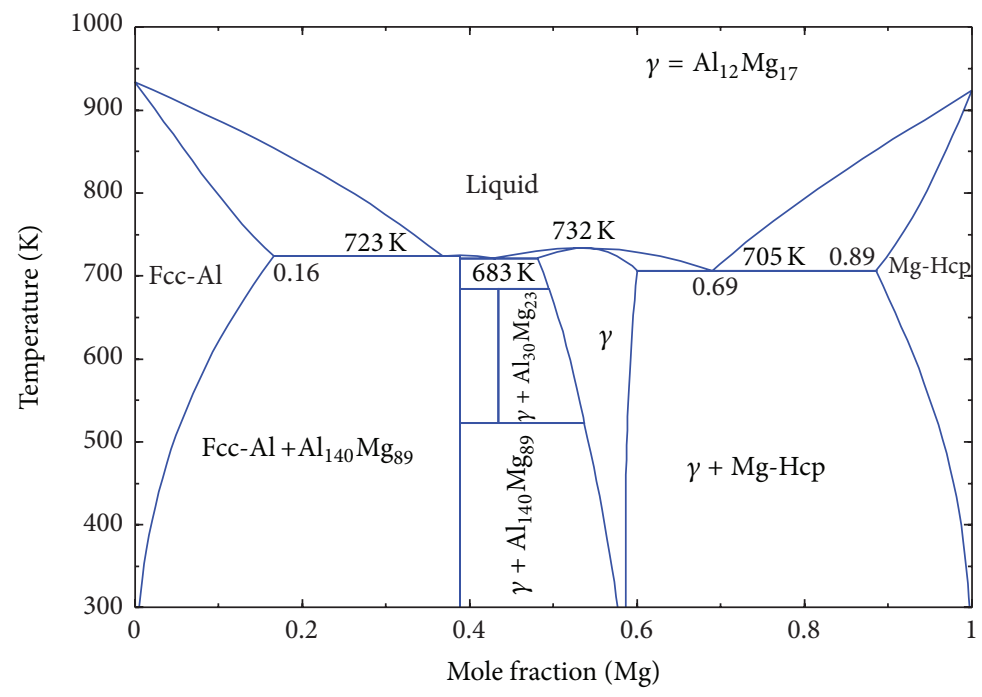

Figure 1: Mg-Al phase diagram.

hexagonal crystal structure, $\gamma$-solid solution with the $\alpha \mathrm{Mn}$ structure type, $\mathrm{R}$ phase with rhombohedral structure at 42 at.\% $\mathrm{Mg}$, Al solid solution with a maximum solubility of 18.9 at. $\% \mathrm{Mg}$ at $723 \mathrm{~K}$, and $\mathrm{Mg}$ solid solution with a maximum solubility of 11.8 at. $\% \mathrm{Al}$ at $710 \mathrm{~K}$. In view of the relative atomic radii of $\mathrm{Al}$ and $\mathrm{Mg}$ atoms, the ratio of the $\mathrm{Al}$ radius to that of $\mathrm{Mg}$ is 1.12 which suggests high mutual solid solubility. There is a good agreement between different authors regarding the solid solubility of $\mathrm{Mg}$ and $\mathrm{Al}$, liquidus, solidus, and solvus lines.

Several efforts [96-100] have been made to calculate the $\mathrm{Mg}-\mathrm{Al}$ phase diagram. In addition, Zhong et al. [101] reported a complete thermodynamic description of the Al-Mg binary system using a combined approach of CALPHAD and firstprinciples calculations. They also calculated the enthalpies of formation of $\mathrm{Al}_{30} \mathrm{Mg}_{23}(\varepsilon)$ and $\mathrm{Al}_{12} \mathrm{Mg}_{17}(\gamma)$ as well as the enthalpies of mixing of $\mathrm{Al}-\mathrm{fcc}$ and $\mathrm{Mg}$-hcp solution. But experimental measurement of the enthalpy of mixing of the Mg-Al liquid was carried out by [10, 12-14, 21, 102]. Belton and Rao [13] and Tiwari [21] obtained the enthalpy of mixing of $\mathrm{Mg}$-Al liquid from emf measurements at $1073 \mathrm{~K}$, while Bhatt and Garg [12] and Juneja et al. [14] derived the enthalpy of mixing from partial pressure measurements at $1073 \mathrm{~K}$. Agarwal and Sommer [10] measured enthalpy of mixing of $\mathrm{Mg}$-Al liquid using three different calorimetric methods at $943 \mathrm{~K}, 947 \mathrm{~K}, 948 \mathrm{~K}$, and $973 \mathrm{~K}$. In 1998, Moser et al. [11] measured the enthalpy of mixing at $1023 \mathrm{~K}$ using drop calorimetry. The thermodynamic activities of liquid alloys at $1073 \mathrm{~K}$ were determined by $[12,13,18-21,103]$ using emf measurements. The reported results are scattered but show small negative deviation from ideal solution.

Based on the available experimental data from the literature Aljarrah [104] made thermodynamic modeling of the $\mathrm{Mg}$-Al system. Their reported parameters have been used to calculate the phase diagram and thermodynamic properties of the Mg-Al system as shown in Figures 1 and 2 as it provides the most accurate description of the system in terms of phase diagram and thermodynamic properties. The crystallographic information of the intermetallic compounds and optimized parameters are listed in Tables 2 and 3. Also, the enthalpies and entropies of formation of the intermetallic compounds are listed in Table 4.

\section{Mg-Zn (Magnesium-Zinc)}

$\mathrm{Zn}$ is commonly alloyed with $\mathrm{Mg}$ in $\mathrm{AZ}, \mathrm{EZ}, \mathrm{ZK}$ and in smaller amounts in AM and AE series. The liquidus in the $\mathrm{Mg}-\mathrm{Zn}$ phase diagram was determined by Boudouard [105] using thermal analysis. He [105] introduced a compound with $\mathrm{Mg}_{4} \mathrm{Zn}$ formula. Grube [106] found that Boudouard's [105] measurements were in error due to contaminations and the $\mathrm{Mg}_{4} \mathrm{Zn}$ compound did not exist. Moreover, he [106] found an intermetallic compound that corresponds to $\mathrm{MgZn}_{2}$ and melts at $868 \mathrm{~K}$. The compound forms a eutectic with pure $\mathrm{Zn}$ at 97 at.\% $\mathrm{Zn}$ and $641 \mathrm{~K}$. No solid solution areas were defined in the system $[105,106]$. Chadwick [107] found a new solid solution $\beta$ near the composition $\mathrm{MgZn}_{5}$ and reported that $\mathrm{MgZn}_{2}$ forms a wide range of solid solution. However, his [107] results showed higher content of zinc due to the presence of Si impurity. Chadwick [107] also measured the liquidus line in the $\mathrm{Mg}$ - $\mathrm{Zn}$ phase diagram using thermal analysis. The reported values agree reasonably with the liquidus suggested by Grube [106]. The compound $\mathrm{MgZn}_{5}$ was first discovered by Chadwick [107] and later on replaced by $\mathrm{Mg}_{2} \mathrm{Zn}_{11}$ based on the more reliable X-ray analysis by Samson [108]. On the other hand, Park and Wyman [109] reported the maximum solubility of $\mathrm{Zn}$ in $\mathrm{Mg}$ as 2.5 at. $\% \mathrm{Zn}$ at $340^{\circ} \mathrm{C}$; also, they [109] measured the narrow homogeneity range of $\mathrm{MgZn}_{2}$ as 1.1 at.\% $\mathrm{Zn}$ (from 66 at.\% $\mathrm{Zn}$ at $416^{\circ} \mathrm{C}$ to 67.1 at. $\% \mathrm{Zn}$ at $654 \mathrm{~K}$ ). Hume-Rothery [110] studied the system in the composition range of 30 to 100 at.\% $\mathrm{Zn}$ using thermal analysis and microscopic inspection. Accordingly, the maximum limited solubility of $\mathrm{Mg}$ in $\mathrm{Zn}$ was determined as 0.3 at. $\%$ at $673 \mathrm{~K}$. Laves [111] identified $\mathrm{Mg}_{2} \mathrm{Zn}_{3}$ phase 


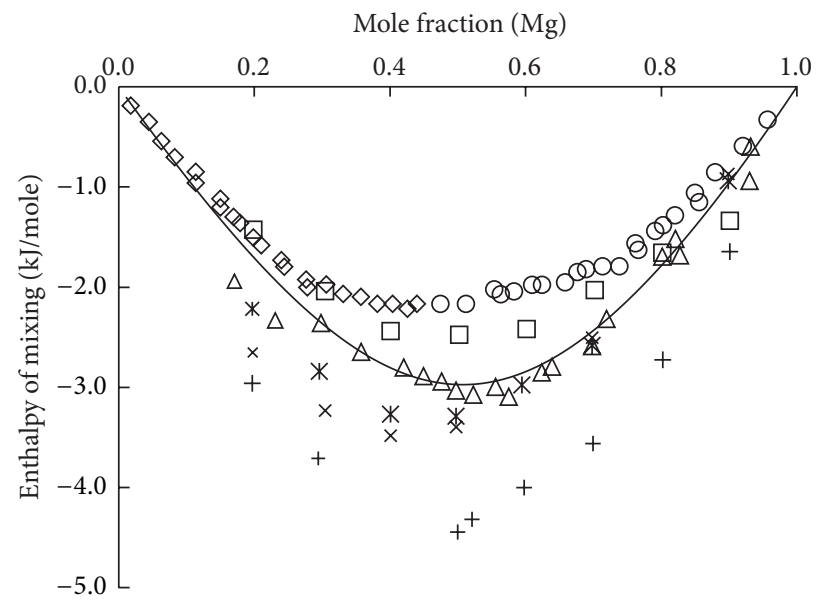

(a)

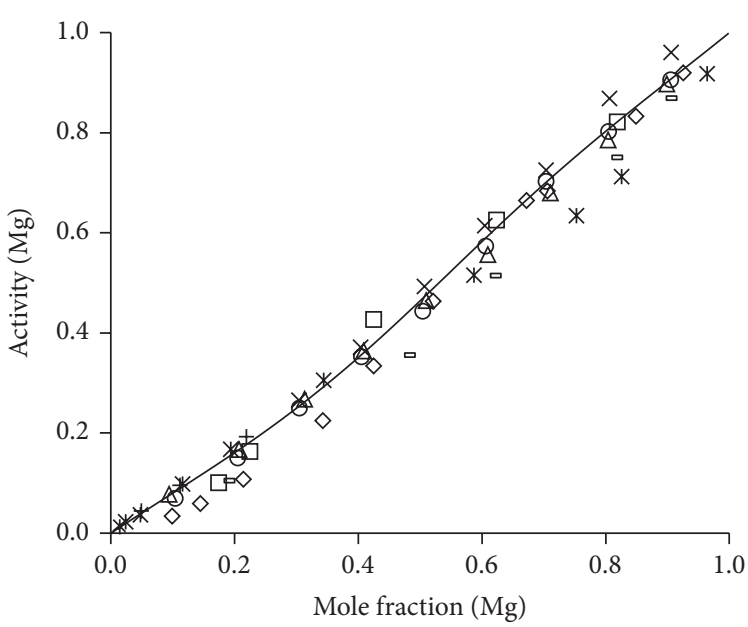

(b)

Figure 2: Calculated (a) enthalpy of mixing of liquid Mg-Al at $1073 \mathrm{~K}: \mathrm{O}:[10]$ at $948 \mathrm{~K}, \diamond:[10]$ at $973 \mathrm{~K}, \triangle$ : [11] at $1073 \mathrm{~K}, \square:[12]$ at $1073 \mathrm{~K}, \times$ : [13] at $1073 \mathrm{~K},+:$ [14] at $1073 \mathrm{~K}, *:$ [15] at $973 \mathrm{~K}, \square:$ [16] at $1002 \mathrm{~K}, \mathrm{O}:$ [16] at $1008 \mathrm{~K}$. (b) Activity of liquid Mg $1073 \mathrm{~K}: \bigcirc:$ [14] at 1073 K, $\triangle$ [17] at $923 \mathrm{~K}, \times$ : [18] at $923 \mathrm{~K}, \square:$ [19] at $1073 \mathrm{~K}, \diamond:$ [13] at $1123 \mathrm{~K}, \star:$ [20] at $1073 \mathrm{~K},+:$ [12] at $1073 \mathrm{~K}, *:$ [21] at $1073 \mathrm{~K}$.

TABLE 2: Crystal structure data for Mg-Al intermetallic compounds.

\begin{tabular}{|c|c|c|c|c|c|c|c|}
\hline \multirow{2}{*}{ Phase } & \multirow{2}{*}{ Prototype } & \multirow{2}{*}{ Space group number } & \multirow{2}{*}{ Space group } & \multicolumn{3}{|c|}{ Lattice parameter (nm) } & \multirow{2}{*}{ Reference } \\
\hline & & & & $a$ & $b$ & $c$ & \\
\hline $\mathrm{Al}_{30} \mathrm{Mg}_{23}(\varepsilon)$ & $\mathrm{Al}_{30} \mathrm{Mg}_{23}$ & 148 & $\mathrm{R} \overline{3} \mathrm{~h}$ & 1.2825 & 1.2825 & 2.1748 & [137] \\
\hline $\mathrm{Al}_{140} \mathrm{Mg}_{89}(\beta)$ & $\mathrm{Al}_{45} \mathrm{Mg}_{28}$ & 227 & $\mathrm{~F} \mathrm{D} \overline{3} \mathrm{~m}$ & 2.8300 & 2.8300 & 2.8300 & [137] \\
\hline $\mathrm{Al}_{12} \mathrm{Mg}_{17}(\gamma)$ & $\mathrm{Al}_{12} \mathrm{Mg}_{17}$ & 217 & $\mathrm{I} 4 \overline{3} \mathrm{~m}$ & 1.0544 & 1.0544 & 1.0544 & [137] \\
\hline
\end{tabular}

TABLE 3: Optimized model parameters of the Mg-Al system [41].

\begin{tabular}{|c|c|}
\hline Phase & $\begin{array}{c}\text { Parameters } \\
\Delta g^{0} \text { and }{ }^{0} L \text { in } \mathrm{J} / \text { mole, }{ }^{\circ} \Delta H \text { in } \mathrm{J} / \mathrm{mole} \cdot \text { atom and }{ }^{\circ} \Delta S \text { in } \mathrm{J} / \text { mole } \cdot \text { atom } \cdot \mathrm{K}\end{array}$ \\
\hline Liquid & $\begin{array}{c}\mathrm{Z}_{\mathrm{MgAl}}^{\mathrm{Mg}}=6, \mathrm{Z}_{\mathrm{AlMg}}^{\mathrm{Al}}=4 \\
\Delta g_{\mathrm{MgAl}}^{0}=-4495.5+2.85 T ; \Delta g_{\mathrm{MgAl}}^{10}=436.8+0.42 T \\
\Delta g_{\mathrm{MgAl}}^{01}=732.5\end{array}$ \\
\hline Mg-hcp & $\begin{array}{c}{ }^{0} L^{\mathrm{Mg}-\mathrm{hcp}}=1950.8-2.0 T ;{ }^{1} L^{\mathrm{Mg}-\mathrm{hcp}}=1480.6-2.1 T ; \\
{ }^{2} L^{\mathrm{Mg-hcp}}=3501.5\end{array}$ \\
\hline Al-fcc & $\begin{array}{c}{ }^{0} L^{\mathrm{Al}-\mathrm{fcc}}=4973.1-3.5 T ;{ }^{1} L^{\mathrm{Al}-\mathrm{fcc}}=900.4+0.42 T ; \\
{ }^{2} L^{\mathrm{Al}-\mathrm{fcc}}=950.4\end{array}$ \\
\hline $\begin{array}{l}\mathrm{Al}_{30} \mathrm{Mg}_{23}(\varepsilon) \\
\mathrm{Al}_{140} \mathrm{Mg}_{89}(\beta)\end{array}$ & $\begin{array}{c}{ }^{\mathrm{o}} \Delta H_{\mathrm{AlMg}}^{\mathrm{Al}_{30} \mathrm{Mg}_{23}}=-991.8 ;{ }^{\circ} \Delta S_{\mathrm{Al}, \mathrm{Mg}}^{\mathrm{Al}_{30} \mathrm{Mg}_{23}}=3.27 \\
{ }^{\mathrm{o}} \Delta H_{\mathrm{AlMg}}^{\mathrm{Al}_{140} \mathrm{Mg} g_{89}}=-1075.0 ;{ }^{\circ} \Delta S_{\mathrm{Al}, \mathrm{Mg}}^{\mathrm{Al}_{140} \mathrm{Mg}_{89}}=2.95\end{array}$ \\
\hline $\begin{array}{l}\mathrm{Al}_{12} \mathrm{Mg}_{17}(\gamma) \\
(\mathrm{Mg})_{5}(\mathrm{Al}, \mathrm{Mg})_{12}(\mathrm{Al}, \mathrm{Mg})_{12}\end{array}$ & ${ }^{0} L_{\mathrm{Mg}: \mathrm{Al}: \mathrm{Al}, \mathrm{Mg}}^{\gamma}=3901.7-0.50 T ;{ }^{0} L_{\mathrm{Mg}: \mathrm{Mg}: \mathrm{Al}, \mathrm{Mg}}^{\gamma}=3901.7-0.50 T$ \\
\hline
\end{tabular}

by means of XRD and metallography inspection; he also proved that the phase is at equilibrium with $\mathrm{Mg}$ terminal solid solution at room temperature. The phase equilibria in the $\mathrm{Mg}$ - Zn system from 0 to 67.8 at. $\% \mathrm{Zn}$ were determined by Clark and Rhins [112] using XRD and microscopic analysis. They confirmed the thermal stability range of $\mathrm{MgZn}$ from 366 to $608 \mathrm{~K}$. In addition, they identified the temperature of the eutectoidal decomposition $\mathrm{Mg}_{7} \mathrm{Zn}_{3} \leftrightarrows \alpha-\mathrm{Mg}+\mathrm{MgZn}$ at near
598 K. After careful crystal structure study, Higashi et al. [113] replaced the compound $\mathrm{Mg}_{7} \mathrm{Zn}_{3}$ by $\mathrm{Mg}_{51} \mathrm{Zn}_{20}$ using XRD techniques. Afterwards, the $\mathrm{Mg}-\mathrm{Zn}$ system was assessed by Clark et al. [114] based on the experimental work of $[107,109$, 110]. Using computational thermodynamics, Agarwal et al. [26], Liang et al. [115], Wasiur-Rahman and Medraj [47], and Ghosh et al. [22] performed phase diagram calculations on the $\mathrm{Mg}-\mathrm{Zn}$ system. Five intermetallic compounds $\mathrm{Mg}_{51} \mathrm{Zn}_{20}$, 
TABLE 4: Enthalpy and entropy of formation of the $\mathrm{Mg}$-Al intermetallic compounds.

\begin{tabular}{|c|c|c|c|}
\hline Compound & $\begin{array}{c}\text { Enthalpy of formation } \\
(\mathrm{kJ} / \mathrm{mole} \cdot \mathrm{atom})\end{array}$ & $\begin{array}{c}\text { Entropy of formation } \\
(\mathrm{J} / \mathrm{mole} \cdot \mathrm{atom} \cdot \mathrm{K})\end{array}$ & Reference \\
\hline \multirow{2}{*}{$\mathrm{Al}_{30} \mathrm{Mg}_{23}(\varepsilon)$} & -3.42 & & [101] Cal. (F.P.) \\
\hline & -0.99 & 3.27 & [104] Cal. (Calphad) \\
\hline \multirow{3}{*}{$\mathrm{Al}_{140} \mathrm{Mg}_{89}(\beta)$} & -2.47 & & [138] Exp. \\
\hline & -1.22 & & [139] Exp. \\
\hline & -1.08 & 2.95 & [104] Cal. (Calphad) \\
\hline \multirow{3}{*}{$\mathrm{Al}_{12} \mathrm{Mg}_{17}(\gamma)$} & -3.80 & & [138] Exp. \\
\hline & -1.01 & & [139] Exp. \\
\hline & -3.60 & & [101] Cal. (F.P.) \\
\hline
\end{tabular}

$\mathrm{Mg}_{12} \mathrm{Zn}_{13}, \mathrm{Mg}_{2} \mathrm{Zn}_{3}, \mathrm{MgZn}_{2}$, and $\mathrm{Mg}_{2} \mathrm{Zn}_{11}$ and two terminal solid solutions were reported in their models. Agarwal et al. [26] modeled the compounds as stoichiometric phases, whereas, Liang et al. [115], Wasiur-Rahman and Medraj [47] and Ghosh et al. [22] considered $\mathrm{MgZn}_{2}$ as intermediate solid solution achieving consistency with the experimental results of $[109,114]$.

Based on the assessed thermodynamic parameters by Ghosh et al. [22], the phase diagram and thermodynamic properties of the Mg-Zn system are calculated as shown in Figures 3, 4, and 5. They [22] considered all the available experimental data including the recent measurements of enthalpy and entropy of formation and heat capacity (cp) of the intermediate compounds by Morishita et al. [129-132]. The crystallographic data of the intermetallic compounds as well as the thermodynamic parameters of the Mg-Zn system are listed in Tables 5 and 6, respectively. The enthalpies and entropies of formation of the intermetallic compounds are listed in Table 7.

\section{Mg-Mn (Magnesium-Manganese)}

$\mathrm{Mg}-\mathrm{Mn}$ system is characterized by a wide miscibility gap in the liquid. Very limited experimental data are available on this system and the available data are inconsistent among one another. Most of the available data are on the Mg-rich side describing the limited solid solubility of Mn in Mg. According to Tiner [37], the maximum solid solubility of $\mathrm{Mn}$ in $\mathrm{Mg}$ is 2.0 at.\% Mn at $924 \mathrm{~K}$. But Petrov et al. [133] reported much lower solubility limit as 1.03 at.\% $\mathrm{Mn}$ in $\mathrm{Mg}$ using $\mathrm{X}$-ray analysis. Nayeb-Hashemi and Clark [134] critically assessed the partial equilibrium phase diagram of the Mg-Mn system from 0 at.\% $\mathrm{Mn}$ to 3.0 at.\%. Their evaluation was based on thermal analysis, microscopic observation, and hardness measurements of Petrov et al. [133]. They [134] reported the solubility limit of Mn in $\mathrm{Mg}$ as 0.996 at.\% Mn. No intermediate compounds between $\mathrm{Mg}$ and $\mathrm{Mn}$ terminal sides were detected; this supports the presence of the large miscibility gap in the liquid phase, indicating that $\mathrm{Mg}$ and $\mathrm{Mn}$ atoms prefer to be separated in the liquid and solid phases. The complete Mg-Mn phase diagram was determined by Gröbner et al. [135] using differential thermal analysis (DTA) and thermodynamic modeling. Their estimated solubility limit of $\mathrm{Mn}$ in $\mathrm{Mg}$ was in good agreement with Nayeb-Hashemi and Clark [134]. Two invariant reactions were observed: the peritectic reaction $\mathrm{L}+(\alpha-\mathrm{Mn}) \rightarrow \mathrm{Mg}$ at 0.85 at. $\% \mathrm{Mn}$ and just below $923 \mathrm{~K}$ and the monotectic reaction $\mathrm{L}^{\prime \prime} \rightarrow$ $\mathrm{L}^{\prime}+(\delta-\mathrm{Mn})$ at 96 at.\% $\mathrm{Mn}$ and $1471 \mathrm{~K}$. The calculations of Gröbner et al. [135] are consistent with the measurements of Petrov et al. [133] for both the liquidus curve and the solubility limit of $\mathrm{Mn}$ in Mg. Later, Kang et al. [136] reoptimized the Mg-Mn phase diagram. Their optimized phase diagram agrees well with the DTA results of Gröbner et al. [135]. No experimental data on the consolute temperature of the liquid miscibility gap was found, and the available values are based only on the thermodynamic calculations. Kang et al. [136] calculated the temperature of the liquid miscibility gap as $2175 \mathrm{~K}$, which is lower than that calculated by Gröbner et al. [135] as $3475 \mathrm{~K}$ and by Asgar-Khan and Medraj [32] as $3688 \mathrm{~K}$. The liquid miscibility gap temperature was lowered in the work of Kang et al. [136] to enable good agreement with their work on the Mg-Mn-Y system without using any ternary adjustable parameter for the liquid phase. Recently, a self-consistent thermodynamic model of the $\mathrm{Mg}-\mathrm{Mn}$ phase diagram was developed by Asgar-Khan and Medraj [32]. In most of the cases, they reported consistent calculations with the experimental observations [135].

The crystallographic data of this system and the optimized thermodynamic parameters reported by Asgar-Khan and Medraj [32] are listed in Tables 8 and 9. The calculated phase diagram is shown in Figures 6 and 7.

\section{Mg-Ca (Magnesium-Calcium)}

The first work on phase diagram was reported by Baar [145] who determined the liquidus curves for the $\mathrm{Mg}$-Ca system. But it was found later that the starting materials were of low purity. The melting point of the starting $\mathrm{Ca}$ he used was $1081 \mathrm{~K}$ and for $\mathrm{Mg}$ was $905.6 \mathrm{~K}$, compared to 1115 and $923 \mathrm{~K}$ [146] for pure $\mathrm{Ca}$ and $\mathrm{Mg}$, respectively. Further work on this system was carried out by Paris [147] while he was studying the Mg-Ca-Zn ternary system. Their [147] results differ slightly from those of Baar [145]. However, Paris [147] did not mention the purity of the starting materials. Haughton [148] determined the liquidus temperatures in the Mg-rich region in the composition range of 0 to 26 at.\% Ca. They found that the liquidus temperatures in this composition range are in fair agreement with Vosskühler [149] and Klemm 




Figure 3: Mg-Zn phase diagram [22].

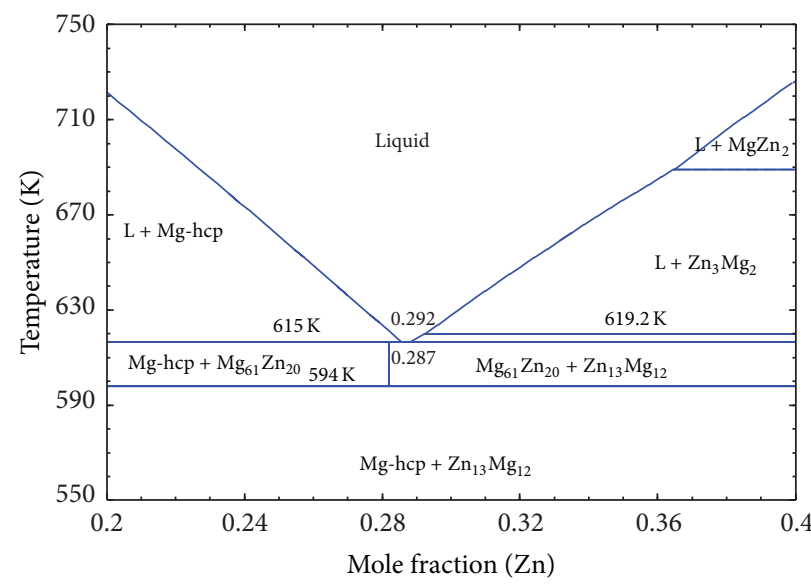

FIGURE 4: Magnified part of the Mg-Zn phase diagram [22].

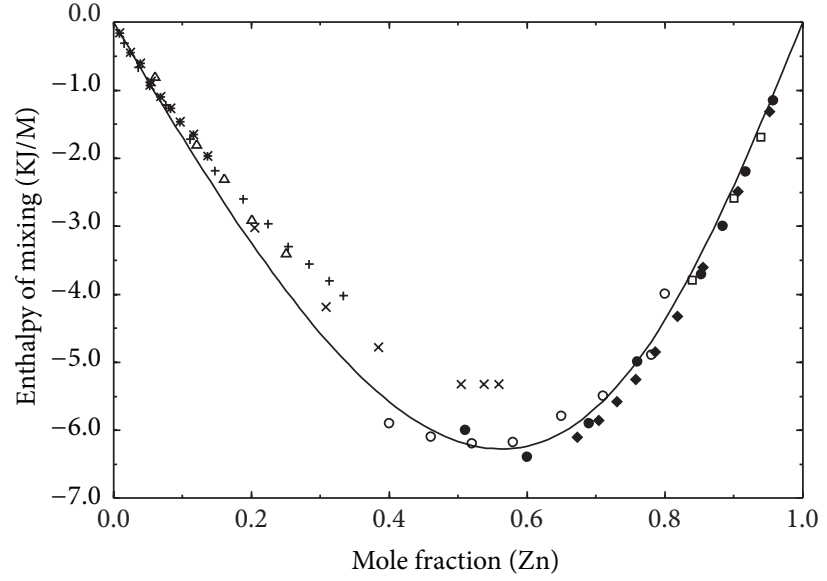

(a)

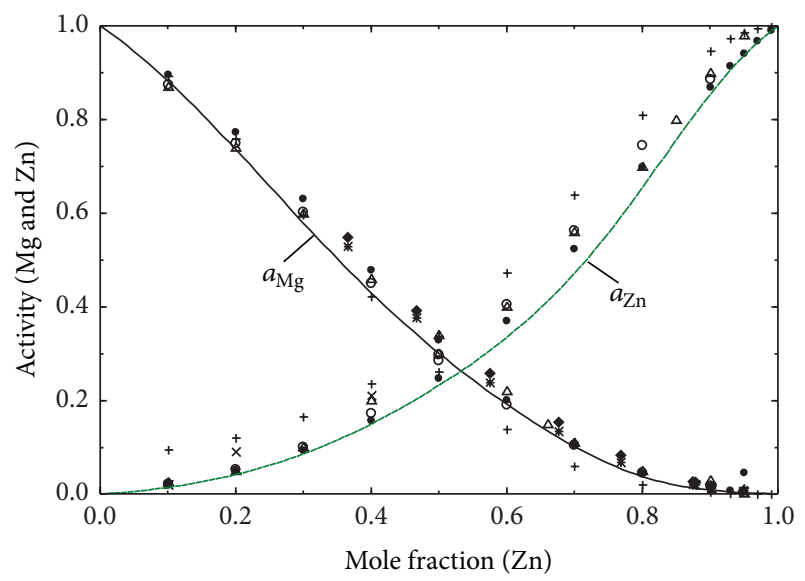

(b)

Figure 5: Calculated (a) enthalpy of mixing of liquid Mg-Zn at $923 \mathrm{~K}:$ O: [24] at $893 \mathrm{~K}, \mathrm{\square}$ : [24] at $842 \mathrm{~K}, \triangle$ : [24] at $931 \mathrm{~K}, \mathbf{\bullet}:$ [25] at 1073 K, [26] at $873 \mathrm{~K}, \times$ : at $933 \mathrm{~K},+$ : at $933 \mathrm{~K}, *$ : at $940 \mathrm{~K}$; (b) Activity of liquid Mg and Zn $923 \mathrm{~K}: \mathrm{O}:$ [27] at $933 \mathrm{~K},+$ : [28] at $680 \mathrm{~K}, \bullet:$ [28] at $880 \mathrm{~K}$, $*$ : [29] at $923 \mathrm{~K}, \triangle:$ [29] at $1000 \mathrm{~K}, \triangle:$ [30], ×: [31] at $943 \mathrm{~K}$. 
TABLE 5: Crystal structure data for Mg-Zn intermetallic compounds.

\begin{tabular}{|c|c|c|c|c|c|c|c|}
\hline \multirow{2}{*}{ Phase } & \multirow{2}{*}{ Prototype } & \multirow{2}{*}{ Space group number } & \multirow{2}{*}{ Space group } & \multicolumn{3}{|c|}{ Lattice parameter (nm) } & \multirow{2}{*}{ Reference } \\
\hline & & & & $a$ & $b$ & $c$ & \\
\hline $\mathrm{Mg}_{51} \mathrm{Zn}_{20}$ & & 71 & Immm & 1.4025 & & & {$[140,141]$} \\
\hline $\mathrm{Mg}_{21} \mathrm{Zn}_{25}$ & & 167 & $R \overline{3}$ ch & 2.5776 & & 0.8762 & {$[140,141]$} \\
\hline $\mathrm{Mg}_{4} \mathrm{Zn}_{7}$ & & 12 & $\mathrm{C} 12 / \mathrm{m} 1$ & 2.5960 & 0.5240 & 1.4280 & {$[140,141]$} \\
\hline $\mathrm{MgZn}_{2}$ & $\mathrm{MgZn}_{2}$ & 164 & $\mathrm{~Pb}_{3} / m m c$ & 0.5220 & & 0.8566 & {$[140,141]$} \\
\hline $\mathrm{Mg}_{2} \mathrm{Zn}_{11}$ & $\mathrm{Mg}_{2} \mathrm{Zn}_{11}$ & 200 & $P m \overline{3}$ & 0.8552 & & & {$[140,141]$} \\
\hline
\end{tabular}

TABLE 6: Optimized model parameters of the Mg-Zn system [22].

\begin{tabular}{|c|c|}
\hline Phase & $\begin{array}{c}\text { Parameters } \\
\Delta g^{0} \text { and }{ }^{0} L \text { in } \mathrm{J} / \mathrm{mole},{ }^{\circ} \Delta H \text { in } \mathrm{J} / \text { mole } \cdot \text { atom } \text { and }{ }^{\circ} \Delta S \text { in } \mathrm{J} / \mathrm{mole} \cdot \text { atom } \cdot \mathrm{K}\end{array}$ \\
\hline Liquid & $\begin{array}{c}\mathrm{Z}_{\mathrm{MgZn}}^{\mathrm{Mg}}=6, \mathrm{Z}_{\mathrm{ZnMg}}^{\mathrm{Zn}}=4 \\
\Delta g_{\mathrm{MgZn}}^{0}=-8326.2+3.19 T ; \Delta g_{\mathrm{MgZn}}^{10}=-4602.4-3.26 T \\
\Delta g_{\mathrm{MgZn}}^{01}=-62.8-3.76 T(\mathrm{~J} / \mathrm{mole})\end{array}$ \\
\hline $\begin{array}{l}\text { Mg-hcp } \\
(\text { Mg in Zn-hcp, Zn } \\
\text { in Mg-hcp) }\end{array}$ & $\begin{array}{l}{ }^{0} L^{\mathrm{Mg}-\mathrm{hcp}}=-3502.5+5.64 T \\
{ }^{1} L^{\mathrm{Mg-hcp}}=-6129.9+5.66 T\end{array}$ \\
\hline $\begin{array}{l}\mathrm{Mg}_{2} \mathrm{Zn}_{11} \\
\mathrm{Mg}_{2} \mathrm{Zn}_{3} \\
\mathrm{Mg}_{12} \mathrm{Zn}_{13} \\
\mathrm{Mg}_{51} \mathrm{Zn}_{20}\end{array}$ & 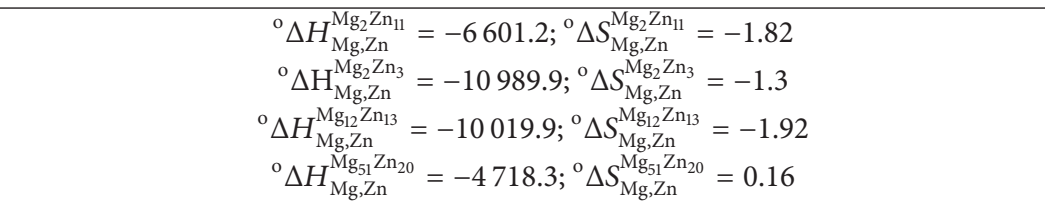 \\
\hline $\begin{array}{l}\mathrm{MgZn}_{2} \\
(\mathrm{Mg} \%, \mathrm{Zn}) \\
(\mathrm{Mg}, \mathrm{Zn} \%)_{2}\end{array}$ & $\begin{array}{c}{ }^{0} G_{\mathrm{Mg}: \mathrm{Mg}}^{\mathrm{MgZn}}=43508.7 ;{ }^{0} G_{\mathrm{Mg}: \mathrm{Zn}}^{\mathrm{MgZn}_{2}}=-55979.2+380.9 T-74 T \ln T+0.00085 T^{2}-3.333 \times \\
{ }^{\mathrm{o}} \Delta H^{\mathrm{MgZn}_{2}}=-33815 ;{ }^{\circ} S^{-6} T^{3} ; \\
{ }^{0} G_{\mathrm{ZnZ}: \mathrm{Mg}}^{\mathrm{Mgn} n_{2}}=30012.9 ;{ }^{0} G_{\mathrm{ZnZZn}}^{\mathrm{MgZn}_{2}}=20008.6 ; \\
{ }^{0} L_{\mathrm{Mg}, \mathrm{Zn}: \mathrm{Mg}}^{\mathrm{MgZn_{2 }}}={ }^{0} L_{\mathrm{Mg}, \mathrm{Zn}: \mathrm{Zn}}^{\mathrm{MgZn}}={ }^{0} L_{\mathrm{Mg}: \mathrm{Mg}, \mathrm{Zn}}^{\mathrm{MgZn}_{2}}={ }^{0} L_{\mathrm{Zn}: \mathrm{Mg}, \mathrm{Zn}}^{\mathrm{MgZn}}=1.0\end{array}$ \\
\hline
\end{tabular}

TABLE 7: Enthalpy and entropy of formation of the Mg-Zn intermetallic compounds.

\begin{tabular}{|c|c|c|c|}
\hline Compound & $\begin{array}{l}\text { Enthalpy of formation } \\
(\mathrm{kJ} / \mathrm{mole} \cdot \text { atom })\end{array}$ & $\begin{array}{c}\text { Entropy of formation } \\
(\mathrm{J} / \text { mole } \cdot \text { atom } \cdot \mathrm{K})\end{array}$ & Reference \\
\hline $\mathrm{Mg}_{51} \mathrm{Zn}_{20}$ & -4.72 & 0.16 & [22] Cal. (Calphad) \\
\hline \multirow{5}{*}{$\mathrm{Mg}_{12} \mathrm{Zn}_{13}$} & $-10.5 \pm 3.1$ & & [142] Exp. \\
\hline & $-8.9 \pm 0.4$ & & [77] Exp. \\
\hline & $-12.14 \pm 3$ & & [130] Exp. \\
\hline & -10.02 & -1.92 & [22] Cal. (Calphad) \\
\hline & $-7.9 \pm 3.1$ & & [143] Exp. \\
\hline \multirow{2}{*}{$\mathrm{Mg}_{2} \mathrm{Zn}_{3}$} & $-13.96 \pm 3$ & & [130] Exp. \\
\hline & -10.99 & -1.3 & [22] Cal. (Calphad) \\
\hline \multirow{6}{*}{$\mathrm{MgZn}_{2}$} & -17.6 & & [144] Exp. \\
\hline & $-15.05 \pm 1.1$ & & [142] Exp. \\
\hline & $-10.9 \pm 0.4$ & & [77] Exp. \\
\hline & $-13.8 \pm 3$ & & [130] Exp. \\
\hline & -18.66 & & [22] Cal. (Calphad) \\
\hline & $-10.4 \pm 1.5$ & & [143] Exp. \\
\hline \multirow{3}{*}{$\mathrm{Mg}_{2} \mathrm{Zn}_{11}$} & $-10.0 \pm 2.5$ & & [142] Exp. \\
\hline & $-8.96 \pm 3$ & & [130] Exp. \\
\hline & -6.60 & -1.82 & [22] Cal. (Calphad) \\
\hline
\end{tabular}


TABLE 8: Crystal structure data for Mg-Mn system.

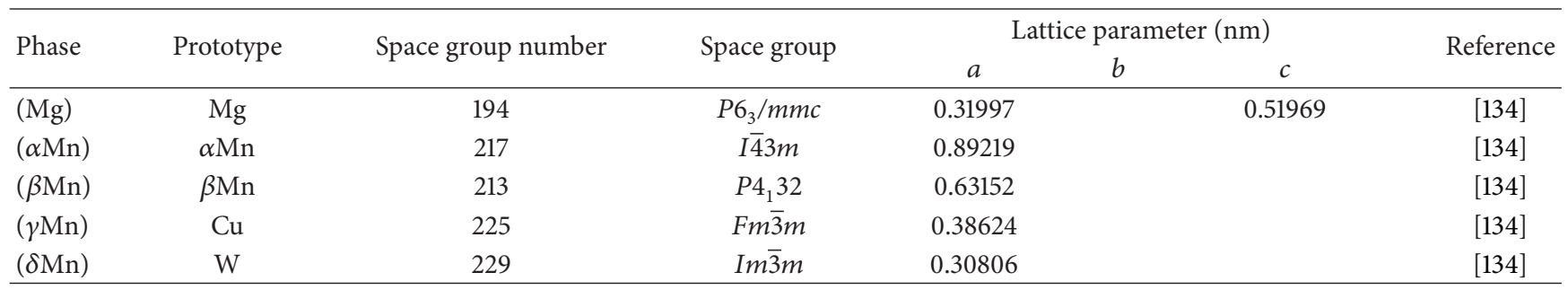

TABLE 9: Optimized model parameters of the Mg-Mn system [32].

\begin{tabular}{lc}
\hline Phase & Parameters $\Delta g^{0}$ and ${ }^{0} L$ in J/mole \\
\hline Liquid & $\mathrm{Z}^{\mathrm{Mg}}{ }_{\mathrm{MgMn}}=4, \mathrm{Z}^{\mathrm{Mg}}{ }_{\mathrm{MnMg}}=6 ;$ \\
\hline Mg-hcp & $\Delta g_{\mathrm{MgMn}}^{0}=-22973.4+0.81 T ; \Delta g_{\mathrm{MgMn}}^{10}=-11995.2 ;$ \\
Mn-fcc & ${ }^{0} L^{\mathrm{Mn}-\mathrm{fcc}}=4785.2-8.83 T ;{ }^{1} L^{\mathrm{Mg}-\mathrm{hcp}}=-3323.5$ \\
$\delta$-fcc & ${ }^{0} L^{\mathrm{Mn}-\mathrm{fcc}}=83716.0$ \\
\hline
\end{tabular}

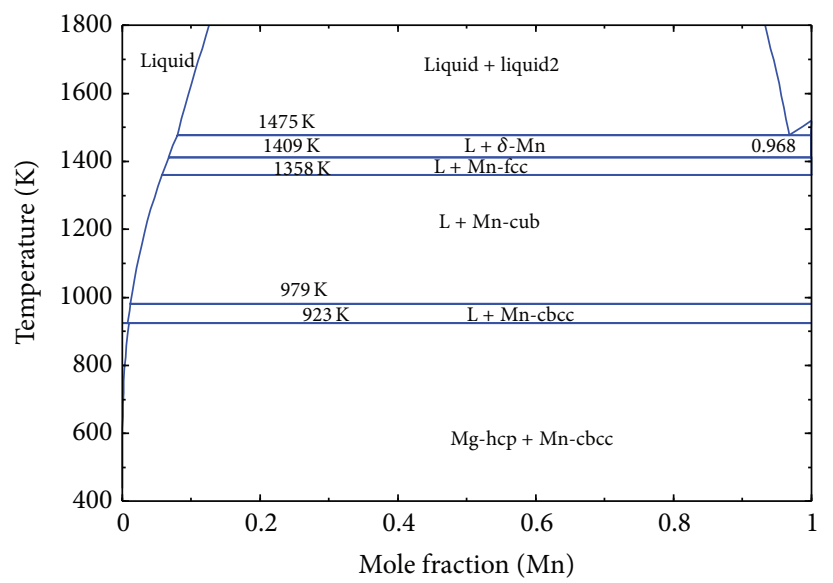

Figure 6: Mg-Mn phase diagram [32].

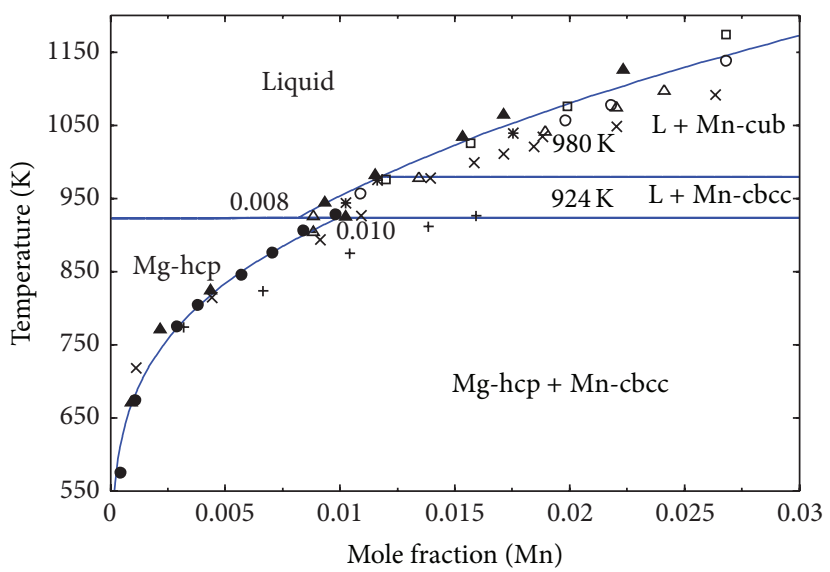

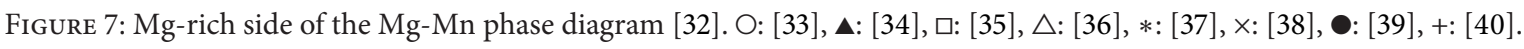


TABle 10: Crystal structure data for Mg-Ca intermetallic compound.

\begin{tabular}{lccccccc}
\hline \multirow{2}{*}{ Phase } & \multirow{2}{*}{ Prototype } & \multirow{2}{*}{ Space group number } & \multirow{2}{*}{ Space group } & \multicolumn{3}{c}{ Lattice parameter (nm) } \\
& & & & $b$ & $c$ & $c$ \\
\hline $\mathrm{Mg}_{2} \mathrm{Ca}$ & $\mathrm{MgZn}_{2}$ & 194 & $P 6_{3} / m m c$ & 0.6253 & 0.6253 & 1.0144 & {$[137]$} \\
\hline
\end{tabular}

TABLE 11: Optimized model parameters of the Mg-Ca system [41].

\begin{tabular}{lc}
\hline Phase & $\begin{array}{c}\text { Parameters } \\
\Delta g^{0} \text { and }{ }^{0} L \text { in } \mathrm{J} / \mathrm{mole},{ }^{\circ} \Delta H \text { in } / \text { mole } \cdot \text { atom } \text { and }{ }^{\circ} \Delta S \text { in } \mathrm{J} / \mathrm{mole} \cdot \text { atom } \cdot \mathrm{K}\end{array}$ \\
\hline Liquid & $\mathrm{Z}^{\mathrm{Mg}}{ }_{\mathrm{MgCa}}=5, \mathrm{Z}^{\mathrm{Ca}}{ }_{\mathrm{CaMg}}=4 ;$ \\
\hline $\begin{array}{l}\text { Mg-hcp } \\
\mathrm{Mg}{ }_{2} \mathrm{Ca}\end{array}$ & $g_{\mathrm{MgCa}}^{0}=-13206.20+9.37 T ; \Delta g_{\mathrm{MgCa}}^{10}=6918.14-21.03 T ; \Delta g_{\mathrm{MgCa}}^{01}=8911.57-15.11$ \\
\hline
\end{tabular}

and Dinkelacker [150] but differ slightly from those given by Baar [145]. Haughton [148] reported that the invariant reaction in the $\mathrm{Mg}$-rich region occurs at $10.5 \pm 0.5$ at. $\% \mathrm{Ca}$ and $790 \mathrm{~K}$, compared to Baar's results as 12.46 at.\% Ca and $787 \mathrm{~K}$. Whereas, Klemm and Dinkelacker's [150] values are 10.5 at.\% $\mathrm{Ca}$ and $789.5 \mathrm{~K}$ which are in good accord with Haughton [148].

Several researchers [148-150,159-161] measured the solubility of Ca in Mg. Among them Burke [160] and Vosskühler [149] reported limited solubility and their results agree fairly well, whereas other researchers reported larger solubility.

Agarwal et al. [166] measured the enthalpy of mixing of liquid $\mathrm{Mg}$-Ca alloy calorimetrically at $1023 \mathrm{~K}$ and heat contents of $\mathrm{Mg}_{2} \mathrm{Ca}$ between 750 and $1150 \mathrm{~K}$. They used these values together with the experimental phase equilibria from [148-150] to calculate the phase diagram of the $\mathrm{Mg}-\mathrm{Ca}$ system. The enthalpy of mixing measured by Sommer et al. [58] was not used since it contradicts with their measurement. Many efforts had been made to measure the heat of formation of the compound $\mathrm{Mg}_{2} \mathrm{Ca}[77,144,151-155,166,167]$. The crystallographic information of this compound is listed in Table 10. Mashovets and Puchkov [59] and Sommer [60] determined the activity of $\mathrm{Mg}$ and $\mathrm{Ca}$ in $\mathrm{Mg}$-Ca liquid at 1080, 1200 , and $1010 \mathrm{~K}$ using vapor pressure measurement.

Nayeb-Hashemi and Clark [177] critically assessed this system based on the liquidus temperatures and the eutectic reactions of Vosskühler [149] and Klemm and Dinkelacker [150]. However, they [177] placed the melting point of $\mathrm{Mg}_{2} \mathrm{Ca}$ at $988 \mathrm{~K}$ which is the average temperature measured by Baar [145] and Vosskühler [149].

Zhong et al. [156] used first principle calculations based on the density functional theory to assess the Mg-Ca system. They determined the total energies of the pure elements of various stable phases at $0 \mathrm{~K}$. They also calculated the enthalpies of formation of the four end-members of $\mathrm{Mg}_{2} \mathrm{Ca}$ which were then used as input data in the optimization process. Their results are in good agreement with those form Zhang et al. [71] and Yang et al. [157] who also performed first principle calculations.

Later, Aljarrah and Medraj [41] optimized the Mg-Ca system using all the available experimental data. Their [41] assessed parameters are listed in Table 11. The Mg-Ca phase diagram and thermodynamic properties in Figures 8 and 9 are calculated based on their [41] reported parameters as they showed better agreement with the available experimental data. The enthalpy and entropy of formation of $\mathrm{Mg}_{2} \mathrm{Ca}$ obtained from different sources are summarized in Table 12.

\section{Mg-Sr (Magnesium-Strontium)}

Nayeb-Hashemi and Clark [178] reviewed the Mg-Sr system and their article provides a comprehensive discussion of all the experimental results obtained by previous researchers $[150,178-181]$. The liquidus surface of the Mg-Sr system was established based on the experimental work of [150, 180-182]. Zhong et al. [158] provided a fine assessment of the liquids experimental data and select them according to the accuracy of the experiments during their optimization. The solid solubility of Mg in Sr has been investigated by Brown [180] and Ray [181]. But according to Nayeb-Hashemi and Clark [178] despite the possibility of hydrogen contamination of Brown's [180] samples, the solidus temperatures he obtained were more realistic than those of Ray [181]. Thermal and metallographic analysis by Brown [180] indicated a very small solid solubility of $\mathrm{Sr}$ in $\mathrm{Mg}(<0.5$ at.\% Sr). This was considered negligible in the optimization of the $\mathrm{Mg}$-Sr phase diagram by Chartrand and Pelton [96].

King and Kleppa [77] used calorimetric method to measure the heat of formation of $\mathrm{Mg}_{2} \mathrm{Sr}$. Zhong et al. [158] predicted the heat of formation of all the intermetallic compounds in the $\mathrm{Mg}$-Sr system using first-principles calculations. Sommer et al. [58] determined the enthalpy of mixing of the liquid alloys at $1080 \mathrm{~K}$, using high temperature calorimetry. The thermodynamic activities of liquid alloys at $1054 \mathrm{~K}$ were determined by Sommer [61] using a modified Ruff boiling technique.

Zhong et al. [158] utilized the results of first principle calculations on the heat of formation along with other experimental data and provided a set of Gibbs energy parameters for the $\mathrm{Mg}$-Sr system. The heat of formation reported by Zhong et al. [158] is in fair agreement with this of Yang et al. [157] who also employed first principles calculations to study the structural, heat of formation, elastic property, and density state of this compound. 


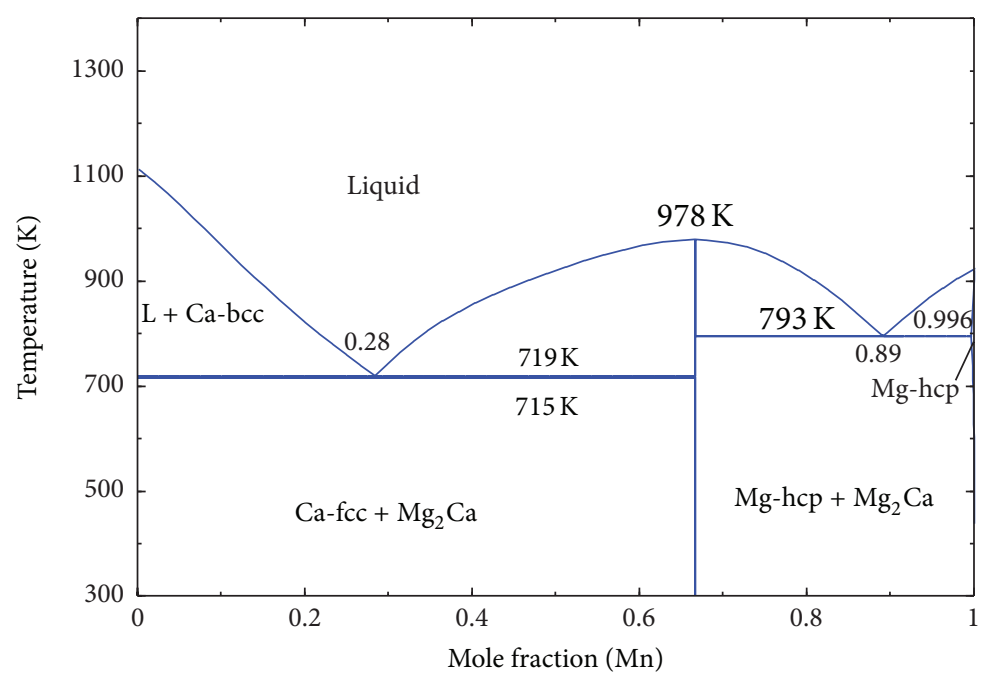

FIgURE 8: Mg-Ca phase diagram [41].



(a)

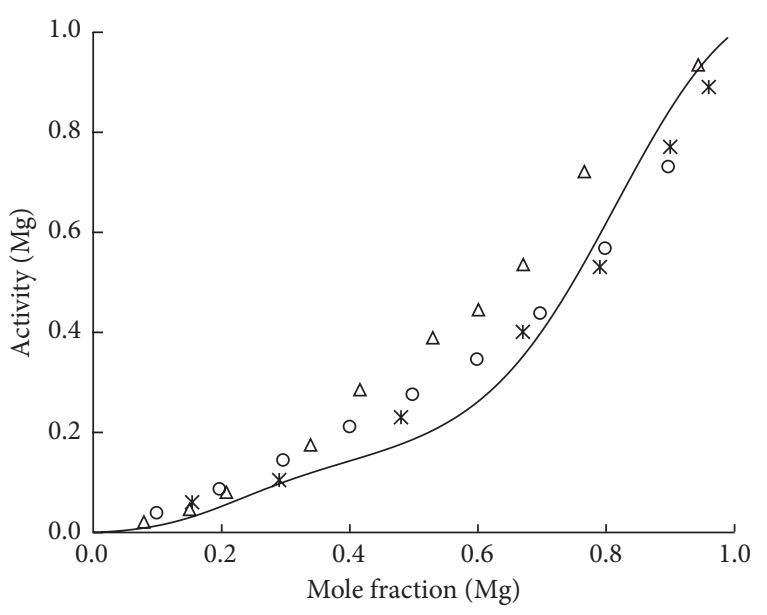

(b)

Figure 9: Calculated (a) enthalpy of mixing of liquid Mg-Ca at $1150 \mathrm{~K}: \mathrm{O}$ [ [58]. (b) Activity of liquid Mg at $1100 \mathrm{~K}: \triangle$ : [59] at 1200 K, *: [59] at $1080 \mathrm{~K}, \mathrm{O}:[60]$ at $1010 \mathrm{~K}$.

TABLE 12: Enthalpy and entropy of formation of $\mathrm{Mg}_{2} \mathrm{Ca}$.

\begin{tabular}{lcc}
\hline $\begin{array}{l}\text { Enthalpy of formation } \\
(\mathrm{kJ} / \mathrm{mole} \cdot \text { atom })\end{array}$ & $\begin{array}{c}\text { Entropy of formation } \\
(\mathrm{J} / \mathrm{mole} \cdot \text { atom } \mathrm{K})\end{array}$ & Reference \\
\hline-13.47 & -1.93 & [41] Cal. (Calphad) \\
$-11.72 \pm 3.77$ & & [151] Exp. \\
-14.59 & [152] Exp. \\
-19.56 & {$[153]$ Exp. } \\
-19.56 & {$[154]$ Exp. } \\
-13.39 & [77] Exp. \\
-20.97 & [155] Exp. \\
-11.72 & [156] Cal. (F.P.) \\
-12.14 & [71] Cal. (F.P.) \\
-12.85 & [157] Cal. (F.P.) \\
\hline
\end{tabular}


TABLE 13: Crystal structure data for Mg-Sr system.

\begin{tabular}{|c|c|c|c|c|c|c|c|}
\hline \multirow{2}{*}{ Phase } & \multirow{2}{*}{ Prototype } & \multirow{2}{*}{ Space group number } & \multirow{2}{*}{ Space group } & \multicolumn{3}{|c|}{ Lattice parameter (nm) } & \multirow{2}{*}{ Reference } \\
\hline & & & & $a$ & $b$ & $c$ & \\
\hline $\mathrm{Mg}_{2} \mathrm{Sr}$ & $\mathrm{MgZn}_{2}$ & 194 & $P 6_{3} / m m c$ & 0.6475 & 0.6475 & 1.0433 & [137] \\
\hline $\mathrm{Mg}_{38} \mathrm{Sr}_{9}$ & $\mathrm{Mg}_{38} \mathrm{Sr}_{9}$ & 194 & $P 6_{3} / m m c$ & 1.0500 & 1.0500 & 2.8251 & [137] \\
\hline $\mathrm{Mg}_{23} \mathrm{Sr} 6$ & $\mathrm{Th}_{6} \mathrm{Mn}_{23}$ & 225 & $F m \overline{3} m$ & 1.5000 & 1.5000 & 1.5000 & [137] \\
\hline $\mathrm{Mg}_{17} \mathrm{Sr}_{2}$ & $\mathrm{Th}_{2} \mathrm{Ni}_{17}$ & 194 & $\mathrm{~Pb}_{3} / \mathrm{mmc}$ & 1.0530 & 1.0530 & 1.0408 & [137] \\
\hline
\end{tabular}

TABLE 14: Optimized model parameters of the Mg-Sr system [41].

\begin{tabular}{|c|c|}
\hline Phase & $\begin{array}{c}\text { Parameters } \\
\Delta g^{0} \text { in } \mathrm{J} / \mathrm{mole},{ }^{\mathrm{o}} \Delta H \text { in } \mathrm{J} / \mathrm{mole} \cdot \mathrm{atom} \text { and }{ }^{\mathrm{o}} \Delta S \text { in } \\
\mathrm{J} / \mathrm{mole} \cdot \text { atom } \cdot \mathrm{K}\end{array}$ \\
\hline Liquid & $\begin{array}{c}\mathrm{Z}_{\mathrm{MgSr}}^{\mathrm{Mg}}=4, \mathrm{Z}_{\mathrm{SrMg}}^{\mathrm{Sr}}=6 \\
\Delta g_{\mathrm{MgSr}}^{0}=-7425.6+2.59 T \\
\Delta g_{\mathrm{MgSr}}^{10}=-1417.3+0.54 T \\
\Delta g_{\mathrm{MgSr}}^{01}=1938.0\end{array}$ \\
\hline $\begin{array}{l}\mathrm{Mg}_{2} \mathrm{Sr} \\
\mathrm{Mg}_{38} \mathrm{Sr}_{9} \\
\mathrm{Mg}_{23} \mathrm{Sr}_{6} \\
\mathrm{Mg}_{17} \mathrm{Sr}_{2}\end{array}$ & 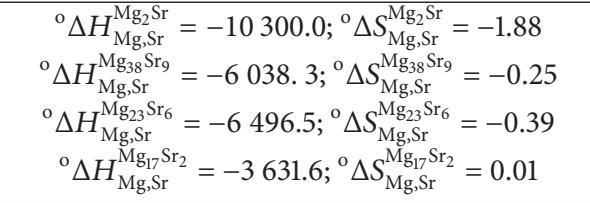 \\
\hline
\end{tabular}

Aljarrah and Medraj [41] reoptimized the Mg-Sr system in the CALPHAD approach considering all the available experimental data on the phase diagram, enthalpy of mixing, and the activities of $\mathrm{Mg}$ and $\mathrm{Sr}$ in the liquid. They [41] used modified quasichemical model to describe the liquid phase. The intermetallic compounds were considered as stoichiometric. The heat of formation of the intermetallic compounds calculated by Aljarrah and Medraj [41] deviated from those of Zhong et al. [158] due to the use of different entropy values as can be seen in Table 15 . The crystallographic data of the intermetallic compounds as well as the optimized model parameters by [41] are listed in Tables 13 and 14 . The phase diagram in Figures 10 and 11 and thermodynamic properties in Figure 12 are calculated using these parameters as it provides the most accurate description of the $\mathrm{Mg}-\mathrm{Sr}$ system. The enthalpies and entropies of formation of the intermetallic compounds are listed in Table 15.

\section{Mg-Y (Magnesium-Yttrium)}

Gibson and Carlson [183] were the first to report the Mg-Y phase diagram. They determined the maximum primary solid solubility of $\mathrm{Y}$ in $\mathrm{Mg}$ as 2.63 at.\% $\mathrm{Y}$ at the eutectic temperature $(840 \mathrm{~K})$. This agrees well with the results of Sviderskaya and Padezhnova [64] who used thermal analysis to study the Mgrich region of the Mg-Y system. Another investigation by Mizer and Clark [184] on this system using thermal analysis and metallography showed that the maximum solubility of $\mathrm{Y}$ in solid $\mathrm{Mg}$ was approximately 3.79 at. $\% \mathrm{Y}$ at $838.5 \mathrm{~K}$. This is, also, in good accord with the results of $[64,183]$.

Smith et al. [65] investigated the crystallography of $\operatorname{MgY}(\gamma), \operatorname{Mg}_{2} \mathrm{Y}(\delta)$, and $\mathrm{Mg}_{24} \mathrm{Y}_{5}(\varepsilon)$ intermediate phases.
The crystallographic data of the compounds are listed in Table 17. Smith et al. [65] also reported the homogeneity ranges of $\mathrm{Mg}_{24} \mathrm{Y}_{5}(\varepsilon)$ and $\operatorname{MgY}(\gamma)$. The $\mathrm{Mg}_{2} \mathrm{Y}(\delta)$ compound was predicted as stoichiometric by $[65,183]$. But their results do not agree with Flandorfer et al. [63], who employed XRD, optical microscopy, and microprobe analyses to study the Ce$\mathrm{Mg}-\mathrm{Y}$ isothermal section at $773 \mathrm{~K}$. Recently, in 2011, Zhao et al. [62] published new information on this system based on diffusion couple and key sample analysis in the temperature range $573-773 \mathrm{~K}$. The homogeneity ranges of $\mathrm{Mg}_{24} \mathrm{Y}_{5}(\varepsilon)$ and $\mathrm{Mg}_{2} \mathrm{Y}(\delta)$ are listed in Table 16. These measurements by [62] showed significantly different solubility ranges especially for $\mathrm{Mg}_{2} \mathrm{Y}(\delta)$ than those from the previous publications $[63,65]$. Also, the solubility of $\mathrm{Y}$ in the Mg-hcp has been adjusted by Zhao et al. [62].

Agarwal et al. [67] measured calorimetrically the enthalpy of mixing of the Mg-Y liquid near the Mg-rich region (up to 21.8 at.\% Y) at different temperatures. Activity of $\mathrm{Mg}$ was measured by Gansen et al. [68] using the vapour pressure technique. Their results are in agreement with those of Gansen and Isper [69] who used the same method for the measurement. The enthalpy of formation of the three compounds was determined calorimetrically by Pyagai et al. [70]. Their results are in reasonable agreement with the calorimetric data of Smith et al. [65] except $\operatorname{MgY}(\gamma)$, for which the value of Pyagai et al. [70] is twice more negative than that obtained by Smith et al. [65]. This is due to the difficulties in measuring the enthalpy of formation when yttrium content increases resulting in more exothermic reactions. Also, $\mathrm{Y}$ has a high melting point compared to $\mathrm{Mg}$ and this leads to the sublimation of Mg during fusion of the metals [67]. The first principle calculation by Zhang et al. [71] and Tao et al. [162] for all the intermetallic compounds in the Mg-Y system showed similar enthalpy of formation values as those of Smith et al. [65].

Thermodynamic modeling of the Mg-Y system has been carried out by Ran et al. [185], Fabrichnaya et al. [186], Al Shakhshir and Medraj [52], Meng et al. [187], Guo et al. [188], Kang et al. [189], and Mezbahul-Islam et al. [66]. Also, Okamoto [190] published the Mg-Y phase diagram based on the assessment of Meng et al. [187]. But, only Kang et al. [189] and Mezbahul-Islam et al. [66] used modified quasi chemical model (MQM) to describe the liquid. Since $\mathrm{Mg}-\mathrm{Y}$ system showed strong short range ordering in the liquid it is more reliable to use MQM in the optimization as it generally provides better predictions in the ternary and higher-order systems [189]. However, the new experimental results on the Mg-Y phase diagram reported by Zhao et al. [62] were not included in any of the previous assessments. 
TABLE 15: Enthalpy and entropy of formation of the Mg-Sr intermetallic compounds.

\begin{tabular}{|c|c|c|c|}
\hline Compound & $\begin{array}{c}\text { Enthalpy of formation } \\
(\mathrm{kJ} / \mathrm{mole} \cdot \text { atom })\end{array}$ & $\begin{array}{c}\text { Entropy of formation } \\
(\mathrm{J} / \mathrm{mole} \cdot \text { atom } \cdot \mathrm{K})\end{array}$ & Reference \\
\hline \multirow{4}{*}{$\mathrm{Mg}_{2} \mathrm{Sr}$} & -7.12 & & [77] Exp. \\
\hline & -10.62 & & [158] Cal. (F.P.) \\
\hline & -10.3 & -1.88 & [41] Cal. (Calphad) \\
\hline & -11.34 & & [157] Cal. (F.P) \\
\hline \multirow{3}{*}{$\mathrm{Mg}_{38} \mathrm{Sr}_{9}$} & -6.27 & & [158] Cal. (F.P.) \\
\hline & -6.74 & & [157] Cal. (F.P) \\
\hline & -6.04 & -0.25 & [41] Cal. (Calphad) \\
\hline \multirow{3}{*}{$\mathrm{Mg}_{23} \mathrm{Sr}_{6}$} & -7.74 & & [158] Cal. (F.P.) \\
\hline & -8.52 & & [157] Cal. (F.P) \\
\hline & -6.50 & -0.39 & [41] Cal. (Calphad) \\
\hline \multirow{3}{*}{$\mathrm{Mg}_{17} \mathrm{Sr}_{2}$} & -4.80 & & [158] Cal. (F.P.) \\
\hline & -5.60 & & [157] Cal. (F.P) \\
\hline & -3.63 & 0.01 & [41] Cal. (Calphad) \\
\hline
\end{tabular}

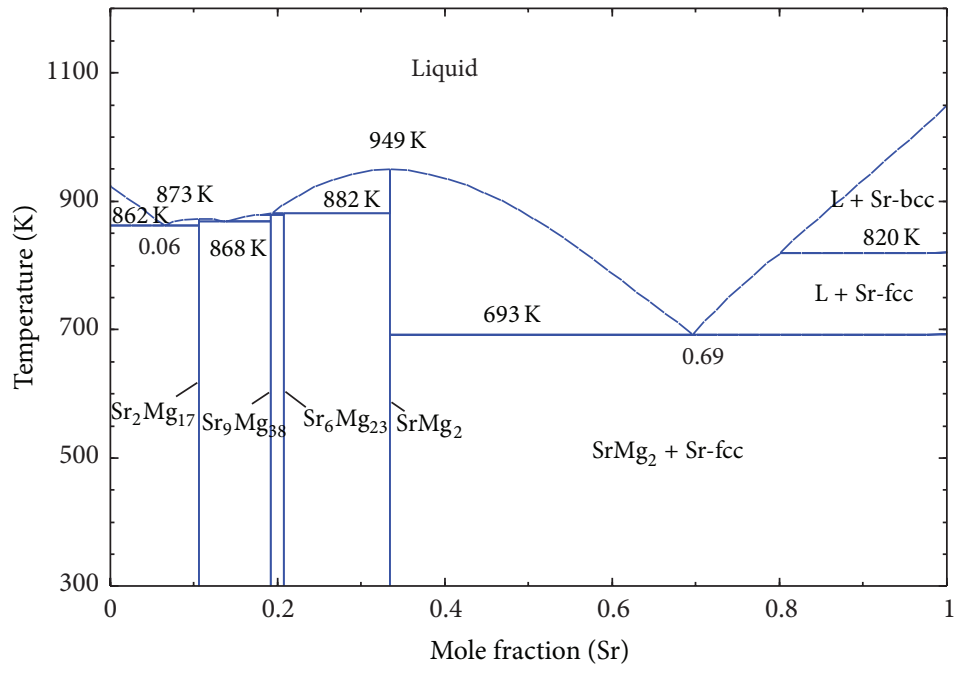

FIGURE 10: Mg-Sr phase diagram.

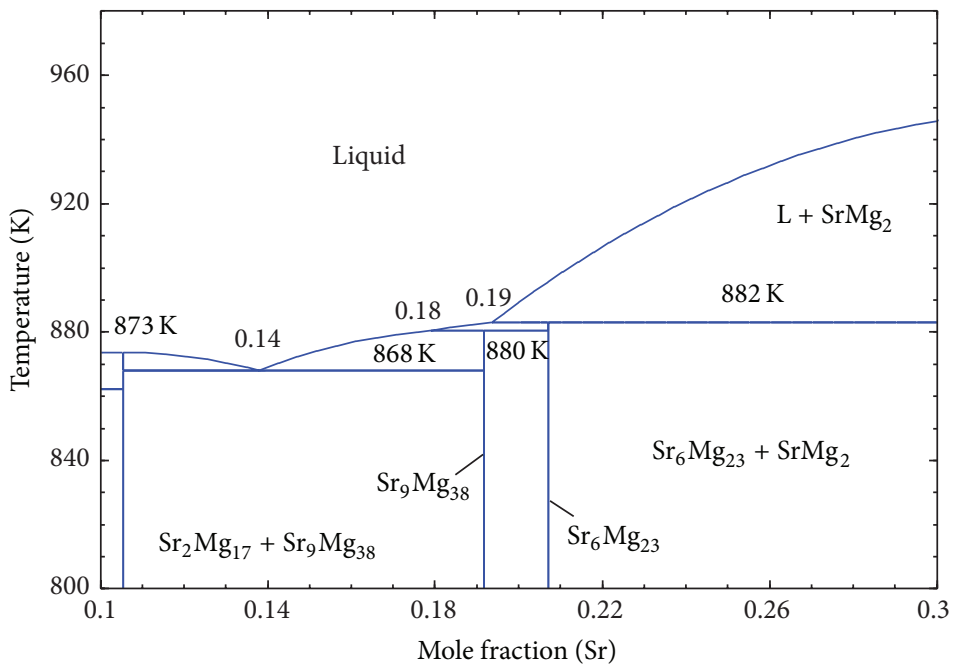

FIgURE 11: Magnified portion of the Mg-Sr phase diagram. 


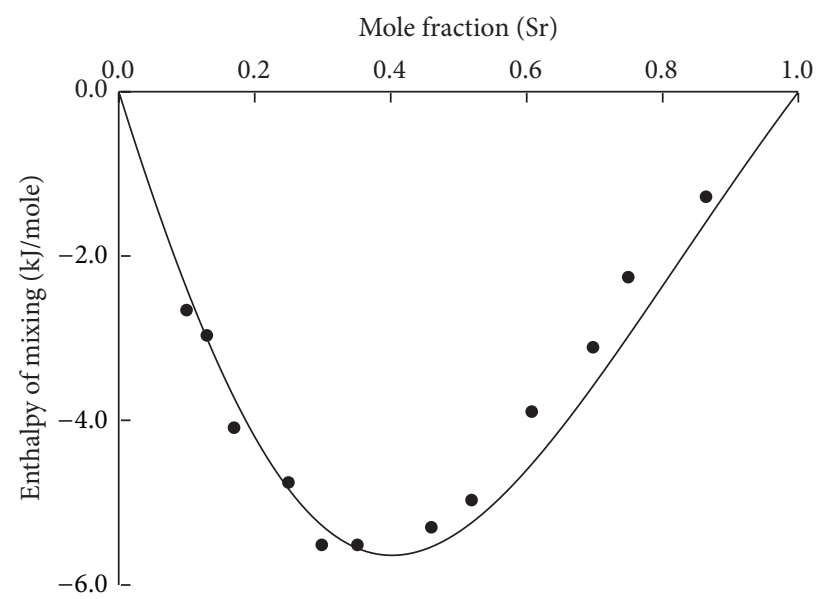

Figure 12: Calculated enthalpy of mixing of liquid Mg-Sr at $1080 \mathrm{~K}: \mathbf{\bullet}:$ [61].

TABLE 16: Experimental data on the homogeneity ranges of $\mathrm{Mg}_{24} \mathrm{Y}_{5}$ $(\varepsilon)$ and $\mathrm{Mg}_{2} \mathrm{Y}(\delta)$.

\begin{tabular}{lccc}
\hline $\begin{array}{l}\text { Temperature, } \\
\mathrm{K}\end{array}$ & $\begin{array}{c}\mathrm{Mg}_{24} \mathrm{Y}_{5}(\varepsilon) \\
\text { at.\% Y }\end{array}$ & $\begin{array}{c}\mathrm{Mg}_{2} \mathrm{Y}(\delta) \\
\text { at.\% } \mathrm{Y}\end{array}$ & Reference \\
\hline 573 & $12.0-16.1$ & $24.0-30.1$ & {$[62]$} \\
623 & $11.9-15.8$ & $24.2-29.5$ & {$[62]$} \\
723 & $11.9-15.6$ & $24.5-31.0$ & {$[62]$} \\
773 & $11.8-15.1$ & $23.6-30.1$ & {$[62]$} \\
$>800$ & $12.0-16.0$ & $33.4-34.5$ & {$[65]$} \\
773 & $12.1-16.1$ & $25.0-34.5$ & {$[63]$} \\
\hline
\end{tabular}

The homogeneity ranges of the intermetallic compounds of this system considered in all the earlier assessments are based on very limited experimental data. Also, those data could have been associated with higher experimental error as they have been measured more than 40 years ago. Zhao et al. [62] used solid-solid diffusion couple technique to determine the solubility of the compounds which usually provides more accurate measurements. Therefore it is decided to consider the recent results of the solubilities of $\mathrm{Mg}_{24} \mathrm{Y}_{5}(\varepsilon)$ and $\mathrm{Mg}_{2} \mathrm{Y}(\delta)$ and reoptimize the $\mathrm{Mg}-\mathrm{Y}$ system in this paper.

The optimized parameters for the $\mathrm{Mg}-\mathrm{Y}$ system are listed in Table 18. During the optimization, the parameters reported by Mezbahul-Islam et al. [66] are used as the staring value as they provided good consistency with the experimental data of the phase diagram and the thermodynamic properties [63$65,67-70,183,184]$. These parameters are then reassessed in light of the recent experimental results of Zhao et al. [62]. Small modifications of the parameters for the liquid, $\mathrm{Mg}_{24} \mathrm{Y}_{5}(\varepsilon)$, and $\mathrm{Mg}_{2} \mathrm{Y}(\delta)$ were necessary to comply with the larger homogeneity range of the intermetallic compounds. The calculated Mg-Y phase diagram based on the recent assessment is shown in Figure 13 with the recently available experimental solubility data of Zhao et al. [62] as well those from Smith et al. [65] and Flandorfer et al. [63]. The phase diagram calculated from the previous optimization from the same authors [66] is shown using dotted line. The difference between these two assessments is mainly along the solubility of the compounds. It can be seen that the present calculation can reproduce the experimental solubility range of $\mathrm{Mg}_{24} \mathrm{Y}_{5}(\varepsilon)$ and $\mathrm{Mg}_{2} \mathrm{Y}(\delta)$ as reported by Zhao et al. [62]. The solubility of $\mathrm{Y}$ in $\mathrm{Mg}$-hcp obtained in this work is about 2.8 at.\% at $773 \mathrm{~K}$ which was reported 4.0 at.\% by Zhao et al. [62]. Attempt to obtain higher $\mathrm{Y}$ solubility in $\mathrm{Mg}$-hcp resulted in poor agreement with the eutectic composition ( $\mathrm{L} \leftrightarrow$ Mg-hcp $\left.+\mathrm{Mg}_{24} \mathrm{Y}_{5}(\varepsilon)\right)$ and temperature data from several other experimental measurements $[64,183,184]$. Also, the authors [62] did not mention the error of measurement of the EPMA which is usually associated with an error of at least \pm 1 at.\%. Hence it is decided to accept the present assessment with lower Y solubility in Mg-hcp. The enthalpy of mixing of the liquid, activity of the liquid $\mathrm{Mg}$, and enthalpy of formation of the intermetallic compounds are calculated as shown in Figures 14(a), 14(b), and 14(c). All the calculations show very good agreement with the available experimental data. The enthalpies and entropies of formation of the intermetallic compounds are listed in Table 19.

\section{Mg-Ni (Magnesium-Nickel)}

Voss [191] was the first researcher who investigated the Mg$\mathrm{Ni}$ system by thermal analysis in the composition range $0.04<X_{\mathrm{Ni}}<0.98$. But in his work, the purity of $\mathrm{Mg}$ was not specified and the purity of $\mathrm{Ni}$ was low (97.7 wt\%). Later, Haughton and Payne [192] determined the liquidus temperature more accurately in the Mg-rich side $(0 \leq$ $X_{\mathrm{Ni}} \leq 0.34$ ) by thermal analysis using high purity elements. Bagnoud and Feschotte [193] investigated the system using XRD, metallography, EPMA and DTA. Micke and Ipser [73] determined the activity of magnesium over the $\mathrm{Mg}-\mathrm{Ni}$ liquid in the $X_{\mathrm{Mg}}>0.65$ composition range by the isopiestic method. They also obtained the liquidus between $0.30<$ $X_{\mathrm{Ni}}<0.40$. According to these investigations, there are two eutectic and one peritectic reactions in the $\mathrm{Mg}-\mathrm{Ni}$ system. Bagnoud and Feschotte [193] investigated the homogeneity range of $\mathrm{MgNi}_{2}$ and mentioned that it extends from 66.2 at.\% $\mathrm{Ni}$ at the peritectic three-phase equilibrium of liquid, 
TABLE 17: Crystal structure data for Mg-Y intermetallic compounds.

\begin{tabular}{|c|c|c|c|c|c|c|c|}
\hline \multirow{2}{*}{ Phase } & \multirow{2}{*}{ Prototype } & \multirow{2}{*}{ Space group number } & \multirow{2}{*}{ Space group } & \multicolumn{3}{|c|}{ Lattice parameter $(\mathrm{nm})$} & \multirow{2}{*}{ Reference } \\
\hline & & & & $a$ & $b$ & $c$ & \\
\hline $\mathrm{Mg}_{24} \mathrm{Y}_{5}(\varepsilon)$ & $\mathrm{Ti}_{5} \mathrm{Re}_{24}$ & 217 & $I \overline{4} 3 m$ & 1.1278 & 1.1278 & 1.1278 & [137] \\
\hline $\operatorname{Mg}_{2} \mathrm{Y}(\delta)$ & $\mathrm{MgZn}_{2}$ & 194 & $\mathrm{PG}_{3} / m m c$ & 0.6018 & 0.6018 & 0.9734 & [137] \\
\hline $\operatorname{MgY}(\gamma)$ & $\mathrm{CsCl}$ & 221 & $P m \overline{3} m$ & 0.3797 & 0.3797 & 0.3797 & [137] \\
\hline
\end{tabular}

TABLE 18: Optimized model parameters of the Mg-Y system (this work).

\begin{tabular}{|c|c|}
\hline Phase & $\begin{array}{l}\text { Parameters } \\
\Delta g^{0} \text { and }{ }^{0} L \text { in } / / \text { mole, }{ }^{\circ} \Delta H \text { in } \mathrm{J} / \text { mole } \cdot \text { atom and }{ }^{\circ} \Delta S \text { in } \mathrm{J} / \text { mole } \cdot \text { atom } \cdot \mathrm{K}\end{array}$ \\
\hline Liquid & $\begin{array}{c}\mathrm{Z}_{\mathrm{MgY}}^{\mathrm{Mg}}=2, \mathrm{Z}_{\mathrm{YMg}}^{\mathrm{Y}}=4 ; \\
\Delta g_{\mathrm{MgY}}^{0}=-13980.6+6.45 T ; \Delta g_{\mathrm{MgY}}^{10}=-15445.6+8.87 T \\
\Delta g_{\mathrm{MgY}}^{01}=5274.1+2.09 T ;\end{array}$ \\
\hline Mg-hcp & $\begin{array}{c}{ }^{0} L^{\mathrm{Mg}-\mathrm{hcp}}=-12476.8+7.49 T \\
{ }^{1} L^{\mathrm{Mg}-\mathrm{hcp}}=-2724.6+2.4 T \\
{ }^{2} L^{\mathrm{Mg}-\mathrm{hcp}}=-2788.2+2.0 T\end{array}$ \\
\hline Y-bcc $(\beta)$ & ${ }^{0} L^{\mathrm{Y}-\mathrm{bcc}}=-28713.7+13.07 T ;{ }^{1} L^{\mathrm{Y}-\mathrm{bcc}}=-2005.9+1.5 T$ \\
\hline $\begin{array}{l}\operatorname{Mg}_{48} \mathrm{Y}_{10}(\varepsilon) \\
(\mathrm{Mg} \%, \mathrm{Y})_{29} \\
(\mathrm{Y} \%, \mathrm{Mg})_{10}(\mathrm{Mg})_{19} \\
\end{array}$ & $\begin{array}{c}{ }^{0} G_{\mathrm{Mg}: \mathrm{Y}: \mathrm{Mg}}^{\varepsilon}=-6179.0 ;{ }^{0} G_{\mathrm{Mg}: \mathrm{Mg}: \mathrm{Mg}}^{\varepsilon}=935.5+0.14 T ; \\
{ }^{0} G_{\mathrm{Y}: Y: M g}^{\varepsilon}=8038.3 ;{ }^{0} G_{\mathrm{Y}: \mathrm{Mg}: \mathrm{Mg}}^{\varepsilon}=721.7(\mathrm{~J} / \mathrm{mole} \cdot \text { atom })\end{array}$ \\
\hline $\begin{array}{l}\mathrm{Mg}_{2} \mathrm{Y}(\delta) \\
(\mathrm{Mg} \%, \mathrm{Y})_{6} \\
(\mathrm{Y} \%, \mathrm{Mg})_{4} \\
(\mathrm{Mg})_{2}\end{array}$ & $\begin{array}{c}{ }^{0} G_{\mathrm{Mg}: Y: M g}^{\delta}=-9767.5+0.66 T ; \\
{ }^{0} G_{\mathrm{Mg}: \mathrm{Mg}: \mathrm{Mg}}^{\delta}=3544.1+1.39 T ; \\
{ }^{0} G_{\mathrm{Y} Y \mathrm{Y}: \mathrm{Mg}}^{\delta}={ }^{0} G_{\mathrm{Y}: \mathrm{Mg}: \mathrm{Mg}}^{\delta}=6976.3 ; \\
{ }^{0} L_{\mathrm{Mg}, \mathrm{Y}: \mathrm{Y}: \mathrm{Mg}}^{\delta}=641.8+11.86 T ; \\
{ }^{0} L_{\mathrm{Mg}, \mathrm{Y}: \mathrm{Mg}: \mathrm{Mg}}^{\delta}={ }^{0} L_{\mathrm{Y}: \mathrm{Y}, \mathrm{Mg}: \mathrm{Mg}}^{\delta}=9006.5+88.60 T ; \\
{ }^{0} L_{\mathrm{Mg}: \mathrm{Y}, \mathrm{Mg}: \mathrm{Mg}}^{\delta}=-2096.2+0.05 T(\mathrm{~J} / \mathrm{mole} \cdot \text { atom })\end{array}$ \\
\hline $\begin{array}{l}\operatorname{MgY}(\gamma) \\
(\mathrm{Mg} \%, \mathrm{Y}) \\
(\mathrm{Y} \%, \mathrm{Va})\end{array}$ & $\begin{array}{c}{ }^{0} G_{\mathrm{Mg}: \mathrm{Y}}^{\gamma}=-10727.3+1.26 T ;{ }^{0} G_{\mathrm{Mg}: \mathrm{Va}}^{\gamma}=-10464.5 ; \\
{ }^{0} G_{\mathrm{Y}: \mathrm{Y}}^{\gamma}={ }^{0} G_{\mathrm{Y}: \mathrm{Va}}^{\gamma}=13483.6 ; \\
{ }^{0} L_{\mathrm{Mg}, \mathrm{Y}: \mathrm{Y}}^{\gamma}=15006.5+16 T ;{ }^{0} L_{\mathrm{Mg}, \mathrm{Y}: \mathrm{Va}}=15006.5+15 T ;{ }^{0} L_{\mathrm{Mg}, \mathrm{Y}: \mathrm{Va}}^{\gamma}={ }^{0} L_{\mathrm{Y}: \mathrm{Y}, \mathrm{Va}}=-5 \\
000.0+7 T(\mathrm{~J} / \text { mole.atom })\end{array}$ \\
\hline
\end{tabular}

TABLE 19: Enthalpy of formation of the Mg-Y intermetallic compounds.

\begin{tabular}{|c|c|c|c|}
\hline Compound & $\begin{array}{c}\text { Enthalpy of formation } \\
(\mathrm{kJ} / \text { mole-atom })\end{array}$ & $\begin{array}{c}\text { Entropy of formation } \\
(\mathrm{J} / \mathrm{mole} \cdot \text { atom } \cdot \mathrm{K})\end{array}$ & Reference \\
\hline \multirow{5}{*}{$\mathrm{Mg}_{24} \mathrm{Y}_{5}(\varepsilon)$} & -6.18 & 0 & This work Cal. (Calphad) \\
\hline & $-7.5 \pm 0.84$ & $0.4 \pm 0.3$ & [65] Exp. \\
\hline & -6.1 & & [70] Exp. \\
\hline & -5.84 & & [71] Cal. (F.P.) \\
\hline & -5.4 & & [162] (F.P.) \\
\hline \multirow{5}{*}{$\mathrm{Mg}_{2} \mathrm{Y}(\delta)$} & -9.77 & -0.66 & This work Cal. (Calphad) \\
\hline & $-14.2 \pm 1.26$ & $-1.3 \pm 0.4$ & [65] Exp. \\
\hline & -12.0 & & [70] Exp. \\
\hline & -9.17 & & [71] (F.P.) \\
\hline & -8.6 & & [162] (F.P.) \\
\hline \multirow{5}{*}{$\operatorname{MgY}(\gamma)$} & -10.7 & -1.26 & This work Cal. (Calphad) \\
\hline & $-12.6 \pm 1.26$ & $-0.3 \pm 4.0$ & [65] Exp. \\
\hline & -30.3 & & [70] Exp. \\
\hline & -10.64 & & {$[71](F . P)$.} \\
\hline & -10.2 & & [162] (F.P.) \\
\hline
\end{tabular}




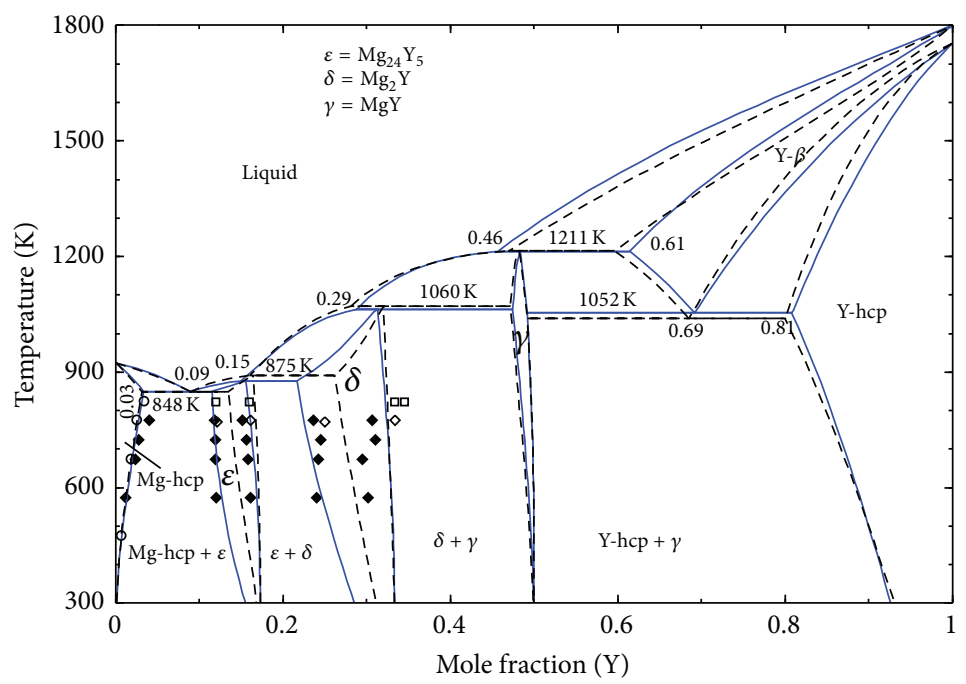

Figure 13: Calculated Mg-Y phase diagram (this work) compared with the literature solid solubility data: $\downarrow$ : [62], \: [63], o: [64], 口: [65]. Dotted line represents the previous assessment [66].



(a)

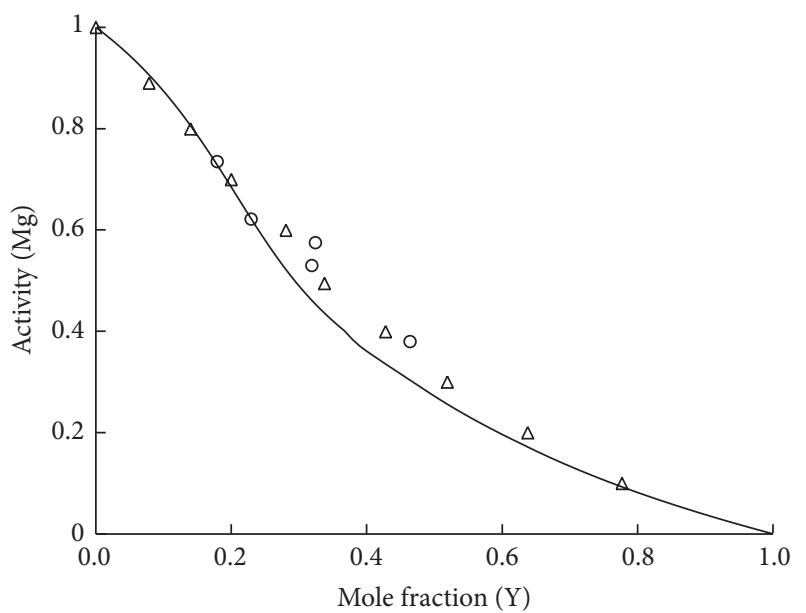

(b)

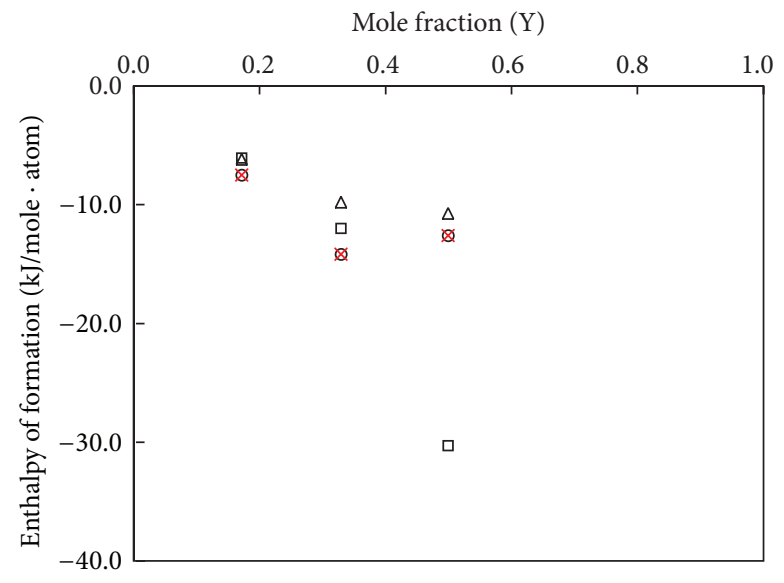

(c)

Figure 14: Calculated (a) enthalpy of mixing of liquid Mg-Y at $984 \mathrm{~K}: \triangle$ : [67] at $975 \mathrm{~K}, \mathrm{O}:[67]$ at $984 \mathrm{~K}$. (b) Activity of liquid Mg at $1173 \mathrm{~K}$ : $\triangle:$ [68], $\bigcirc:[69]$. (c) Enthalpy of formation of the intermetallic compounds: $\triangle$ : [this work]; $\bigcirc:[65] ; \square:[70] ; \times:[71]$. 
TABle 20: Crystal structure data for $\mathrm{Mg}-\mathrm{Ni}$ intermetallic compounds.

\begin{tabular}{|c|c|c|c|c|c|c|c|}
\hline \multirow{2}{*}{ Phase } & \multirow{2}{*}{ Prototype } & \multirow{2}{*}{ Space group number } & \multirow{2}{*}{ Space group } & \multicolumn{3}{|c|}{ Lattice parameter $(\mathrm{nm})$} & \multirow{2}{*}{ Reference } \\
\hline & & & & $a$ & $b$ & $c$ & \\
\hline $\mathrm{Mg}_{2} \mathrm{Ni}$ & $\mathrm{Mg}_{2} \mathrm{Ni}$ & 180 & $P 6_{2} 22$ & 0.5140 & 0.5140 & 1.3220 & {$[163]$} \\
\hline $\mathrm{MgNi}_{2}$ & $\mathrm{MgNi}_{2}$ & 227 & $\mathrm{~Pb}_{3} / \mathrm{mmc}$ & 0.4815 & 0.4815 & 1.5802 & {$[164]$} \\
\hline
\end{tabular}



FIGURE 15: Mg-Ni phase diagram [45].

$\mathrm{Mg}_{2} \mathrm{Ni}$ and $\mathrm{MgNi}_{2}$, to 67.3 at.\% $\mathrm{Ni}$ at the eutectic three phase equilibrium of liquid, $\mathrm{Ni}-\mathrm{fcc}$ and $\mathrm{MgNi}_{2}$.

Haughton and Payne [192] mentioned that the solid solubility of $\mathrm{Ni}$ in $\mathrm{Mg}$ is less than 0.04 at.\% $\mathrm{Ni}$ at $773 \mathrm{~K}$, whereas Merica and Waltenberg [194] reported that the solid solubility of $\mathrm{Mg}$ in $\mathrm{Ni}$ is less than 0.2 at.\% $\mathrm{Mg}$ at $1373 \mathrm{~K}$. Wollam and Wallace [195] and Buschow [163] disputed the ferromagnetic behavior of this system. They investigated the system by heat capacity and magnetic susceptibility measurements and did not find any anomaly in the behavior of $\mathrm{MgNi}_{2}$ at any temperature.

Laves and Witte [164] determined the crystal structure of $\mathrm{MgNi}_{2}$ to be hexagonal hP24-type with 8 molecules per unit cell, and the lattice parameters as $a=0.48147 \mathrm{~nm}$ and $c=1.58019 \mathrm{~nm}$ which are in good agreement with the reported values of Bagnoud and Feschotte [193] and Lieser and Witte [196]. The crystal structure of $\mathrm{Mg}_{2} \mathrm{Ni}$ was determined by Schubert and Anderko [197] who reported a hexagonal, C16-type structure with 6 molecules per unit cell and lattice parameters of $a=0.514 \mathrm{~nm}$ and $c=1.322 \mathrm{~nm}$ which agree with the values reported by Buschow [163]. The crystal structures of the compounds are listed in Table 20.

Feufel and Sommer [16] measured the integral enthalpy of mixing by calorimetric method at $1002 \mathrm{~K}$ and $1008 \mathrm{~K}$. Sryvalin et al. [72] measured the activity of $\mathrm{Mg}$ confirming the results of Micke and Ipser [73] in the composition range $X_{\mathrm{Ni}} \leq$ 0.30. Sieben and Schmahl [74], also, measured the activity of Mg. Experimental data on the heat capacity of $\mathrm{MgNi}_{2}$ is also available. Feufel and Sommer [16] measured the heat capacity from 343 until $803 \mathrm{~K}$ with $20 \mathrm{~K}$ step, whereas, Schubel [75] measured the same at about $100 \mathrm{~K}$ step from 474 to $867 \mathrm{~K}$. Enthalpy of formation of the $\mathrm{MgNi}_{2}$ and $\mathrm{Mg}_{2} \mathrm{Ni}$ compounds was measured by $[74,76-78]$. Also, enthalpies of formation of the compounds were determined using first principle calculations by Zhang et al. [71]. All these data are in reasonable agreement among one another.

Thermodynamic calculations of this system were carried out by Nayeb-Hashemi and Clark [198], Jacobs and Spencer [199] and most recently by Islam and Medraj [43], Xiong et al. [200] and Mezbahul-Islam and Medraj [45]. All these assessments gradually improved the consistency of the phase diagram and thermodynamic properties with the experimental data over years. But with the exception of MezbahulIslam and Medraj [45], none of the modeling considered the short range ordering in the liquid. Hence, their assessed parameters are used here to calculate the phase diagram and thermodynamic properties of the $\mathrm{Mg}-\mathrm{Ni}$ system as shown in Figures 15 and 16. However, in order to be consistent with the experimental Cp data of $\mathrm{MgNi}_{2}$ of Feufel and Sommer [16], temperature dependant higher order terms are added during optimization of $\mathrm{MgNi}_{2}$ in the current assessment. Hence, small adjustment of the optimized parameters of MezbahulIslam and Medraj [45] is made in the current work as shown in Table 21. The calculated enthalpy of formation of $\mathrm{Mg}_{2} \mathrm{Ni}$ and $\mathrm{MgNi}_{2}$ compared with the available experimental data is shown in Figure 16(d) and Table 22.

\section{Mg-Ce (Magnesium-Cerium)}

Using DTA, XRD, and metallography, Wood and Cramer [201] showed that the three compounds $\mathrm{CeMg}_{12}, \mathrm{Ce}_{2} \mathrm{Mg}_{17}$, and $\mathrm{CeMg}_{8.25}$ in the $\mathrm{Mg}$-rich corner were formed peritectically, and the eutectic between $\mathrm{Mg}$ and $\mathrm{CeMg}_{12}$ occurred at $866 \mathrm{~K}$ and 4.2 at.\% Ce. They [201] revealed the existence of $\mathrm{CeMg}_{8,25}$ but did not identify its crystal structure. Later, Johnson and Smith [202] determined the structure of this 


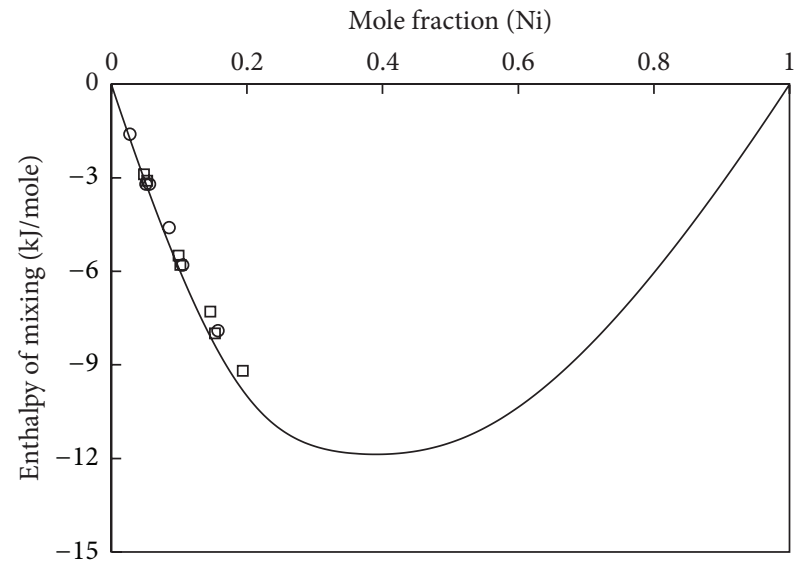

(a)

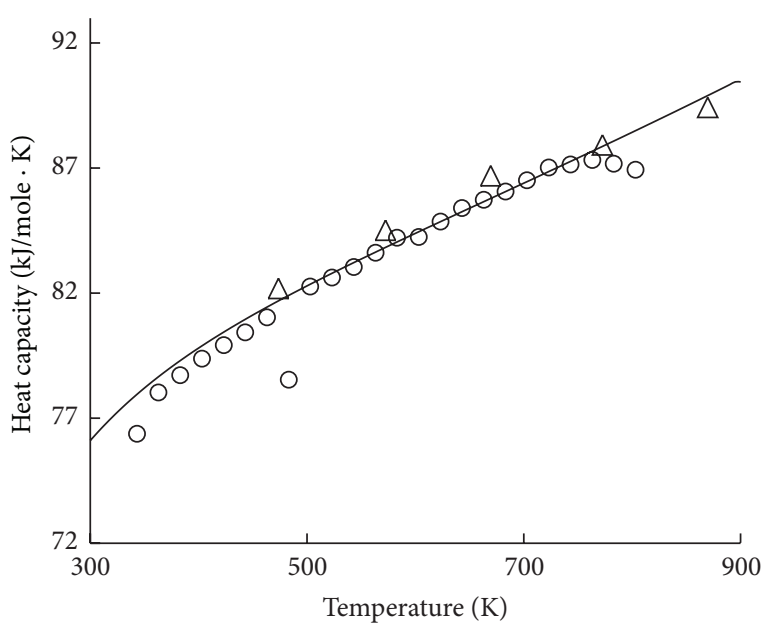

(c)

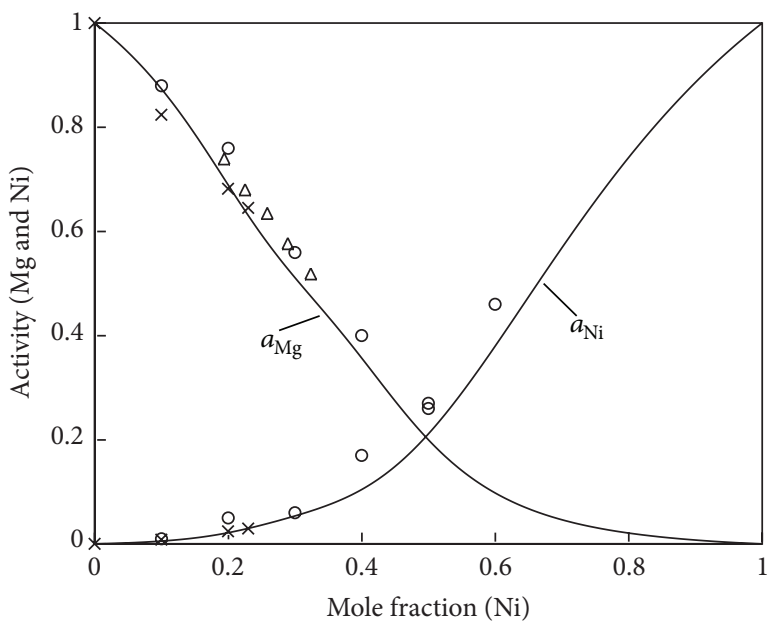

(b)

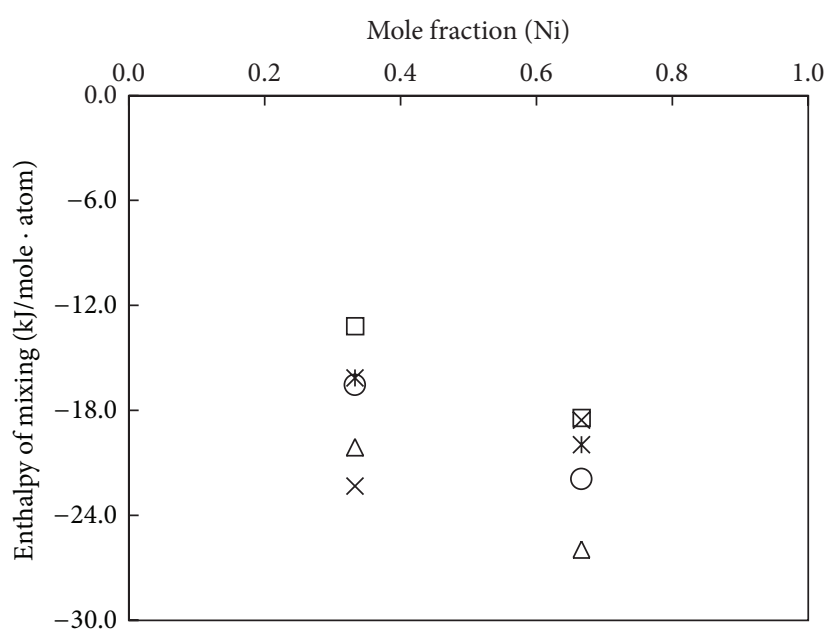

(d)

Figure 16: Calculated (a) enthalpy of mixing of liquid Mg-Ni at $1008 \mathrm{~K}::$ : [16] at $1002 \mathrm{~K}, \mathrm{O}:$ [16] at $1008 \mathrm{~K}$. (b) Activity of liquid Mg and Ni at $1100 \mathrm{~K}: \bigcirc:$ [72] at $1100 \mathrm{~K}, \triangle$ : [73] at $1092 \mathrm{~K}, \times$ : [74] at $1100 \mathrm{~K}$. (c) Heat capacity for the $\mathrm{MgNi}_{2}: \bigcirc:$ [16], $\square$ : [75]. (d) Enthalpy of formation of $\mathrm{Mg}_{2} \mathrm{Ni}$ and $\mathrm{MgNi}_{2}$ : $\bigcirc$ : this work; $\triangle:$ [74]; ×: [76]; $\square:$ [77]; *: [78].

TABLE 21: Optimized model parameters of the Mg-Ni system [45].

\begin{tabular}{|c|c|}
\hline Phase & $\begin{array}{c}\text { Parameters } \\
\Delta g^{0} \text { and }{ }^{0} L \text { in } \mathrm{J} / \text { mole }\end{array}$ \\
\hline Liquid & $\begin{array}{c}\mathrm{Z}_{\mathrm{MgNi}}^{\mathrm{Mg}}=2, \mathrm{Z}_{\mathrm{NiMg}}^{\mathrm{Ni}}=4 \\
\Delta g_{\mathrm{MgNi}}^{0}=-16829.4+5.02 T ; \Delta g_{\mathrm{MgNi}}^{10}=-15068.9+10.49 T \\
\Delta g_{\mathrm{MgNi}}^{01}=-16345.6+1.26 \mathrm{~T}\end{array}$ \\
\hline Mg-hcp & ${ }^{0} L^{\mathrm{Mg-hcp}}=3767.2$ \\
\hline Ni-fcc & ${ }^{0} L^{\mathrm{Ni-fcc}}=36835.0$ \\
\hline $\mathrm{Mg}_{2} \mathrm{Ni}^{*}$ & $\Delta G_{f}=-16075.7+4.66 T(\mathrm{~J} / \mathrm{mole} \cdot$ atom $)$ \\
\hline $\begin{array}{l}\mathrm{MgNi}_{2}{ }^{*} \\
(\mathrm{Mg} \%, \mathrm{Ni})_{1} \\
(\mathrm{Mg}, \mathrm{Ni} \%)_{2}\end{array}$ & $\begin{array}{c}{ }^{\circ} G_{\mathrm{Mg} M \mathrm{Mg}}^{\mathrm{MgNi}_{2}}=8332.6+12.65 T ;{ }^{\circ} G_{\mathrm{Mg}^{\mathrm{Ni}}}^{\mathrm{MgNi}_{2}}= \\
-21431.0+25.24 T-9.39 T \ln T+22.17 \times 10^{-4} T^{2}+6.66 \times 10^{4} T^{-1} ; \\
{ }^{\circ} G_{\mathrm{Ni}: \mathrm{Mg}}^{\mathrm{MgNi}_{2}}=23343.37+4.66 T ;{ }^{\circ} G_{\mathrm{Ni}_{\mathrm{Ni}} \mathrm{Mi}_{2}}^{\mathrm{MNi}_{2}}=4908.55+7.0 T \\
(\mathrm{~J} / \mathrm{mole} \cdot \text { atom })\end{array}$ \\
\hline
\end{tabular}

${ }^{*}$ Modified in this work. 
TABLE 22: Enthalpy and entropy of formation of the Mg-Ni intermetallic compounds.

\begin{tabular}{|c|c|c|c|}
\hline Compound & $\begin{array}{c}\text { Enthalpy of formation } \\
(\mathrm{kJ} / \mathrm{mole} \cdot \text { atom })\end{array}$ & $\begin{array}{c}\text { Entropy of formation } \\
(\mathrm{J} / \mathrm{mole} \cdot \text { atom } \cdot \mathrm{K})\end{array}$ & Reference \\
\hline \multirow{7}{*}{$\mathrm{Mg}_{2} \mathrm{Ni}$} & -16.07 & -4.66 & This work Cal. (Calphad) \\
\hline & -22.33 & $-8.37 \pm 4.05$ & [76] Exp. \\
\hline & -20.09 & -9.21 & [121] Exp. \\
\hline & -16.15 & -4.96 & [78] Exp. \\
\hline & $-13.19 \pm 0.42$ & & [77] Exp. \\
\hline & -19.87 & & [71] Cal. (F.P.) \\
\hline & $-12.1 \pm 2.10$ & & [16] Exp. \\
\hline \multirow{7}{*}{$\mathrm{MgNi}_{2}$} & -21.43 & -25.24 & This work Cal. (Calphad) \\
\hline & -18.56 & $-0.84 \pm 1.95$ & [76] Exp. \\
\hline & -25.96 & -10.89 & [121] Exp. \\
\hline & -19.97 & & [78] Exp. \\
\hline & $-18.42 \pm 0.70$ & -0.83 & [77] Exp. \\
\hline & -25.85 & & [71] Cal. (F.P.) \\
\hline & $-17.7 \pm 3.30$ & & [16] Exp. \\
\hline
\end{tabular}

compound using single crystal X-ray diffraction technique. These authors [202] reported that $\mathrm{CeMg}_{8.25}$ has a body centered tetragonal (BCT) unit cell with $a=14.78 \AA$ and $c=10.43 \AA$ lattice parameters and $I 4 / \mathrm{m}$ space group. Pahlman and Smith [169] studied the thermodynamics of the compound's formation in the Ce-Mg binary system in the temperature range of $650 \mathrm{~K}$ to $930 \mathrm{~K}$. Pahlman and Smith [169] measured the vapour pressure of pure $\mathrm{Mg}$ over Ce-Mg alloys using the knudsen effusion method [151]. From the free energy function $\left(\Delta^{\circ} G=7.98-9.04 \times 10^{-3} \mathrm{~T} \mathrm{~kJ} \cdot \mathrm{mol}^{-1}\right)$, they [169] concluded that $\mathrm{CeMg}_{2}$ should decompose eutectoidally at $875 \mathrm{~K}$. They also reported the eutectoidal decomposition of $\delta$-Ce solid solution at $783 \mathrm{~K}$. Experimental measurement of the heat of formation of the intermetallic compounds was carried out by Nagarajan and Sommer [170], Biltz and Pieper [168] and Pahlman and Smith [169], while first principle calculations to determine the same for the compounds were performed by Tao et al. [162].

The Ce-Mg phase diagram was redrawn by NayebHashemi and Clark [203], considering six intermetallic compounds $\mathrm{CeMg}_{12}, \mathrm{Ce}_{5} \mathrm{Mg}_{41}, \mathrm{CeMg}_{3}, \mathrm{CeMg}, \mathrm{CeMg}_{10.3}$, and $\mathrm{CeMg}_{2}$. With the exception of $\mathrm{CeMg}_{3}$, which melts congruently, all other compounds were considered to be formed peritectically. Later, Saccone et al. [204] studied the $\mathrm{Ce}$-rich and $\mathrm{Mg}$-rich sides of the $\mathrm{Ce}-\mathrm{Mg}$ phase diagram experimentally using XRD, EPMA/SEM, and metallography. Their [204] findings on the eutectoidal decomposition of $\mathrm{CeMg}_{10.3}$ at $886 \mathrm{~K}$, the peritectic formation of $\mathrm{CeMg}_{12}$ at $888 \mathrm{~K}$, and the peritectic formation of $\mathrm{CeMg}_{10.3}$ at $896 \mathrm{~K}$ were in good agreement with the obtained results by Wood and Cramer [201]. Zhang et al. [205] recently suggested slightly shifted compositions for two compounds; $\mathrm{CeMg}_{12}$ was redesignated as $\mathrm{CeMg}_{11}$ and $\mathrm{Ce}_{5} \mathrm{Mg}_{41}$ as $\mathrm{Ce}_{5} \mathrm{Mg}_{39}$. On the other hand, they excluded the $\mathrm{CeMg}_{10.3}$ compound from their version of the phase diagram. More recently, Okamoto [165] put back the compounds former formulae and recommended that the shape of $\mathrm{CeMg}_{3}$ phase field needs to be reexamined. This is because the two-phase region field $\mathrm{CeMg}_{2}+\mathrm{CeMg}_{3}$ in the phase diagram reported by Zhang et al. [205] increases with temperature, which violates the binary phase diagram rules addressed by Okamoto [206].

Thermodynamic modeling of this system has been carried out by Cacciamani et al. [207], Kang et al. [189], and Zhang et al. [208] and later by Ghosh and Medraj [42] using the CALPHAD approach. All these modelings sequentially improved quality of the thermodynamic description of the $\mathrm{Mg}$-Ce system. In the present paper the optimized parameters published by Ghosh and Medraj [42] are used to calculate the phase diagram and thermodynamic properties as these authors provided the latest and most accurate understanding of this system. The calculated $\mathrm{Mg}$-Ce phase diagram and thermodynamic properties of the liquid are shown in Figures 17,18 , and 19. The crystallographic data of the compounds and the thermodynamic parameter set are listed in Tables 23 and 24. Also, the enthalpies and entropies of formation of the intermetallic compounds collected from different sources are listed in Table 25.

\section{Mg-Nd (Magnesium-Nyodymium)}

The terminal solid solubility of $\mathrm{Nd}$ in $\mathrm{Mg}$ was determined by Park and Wyman [109] and Drits et al. [34] at the $819 \mathrm{~K}$ eutectic temperature as 0.1 at.\% Nd. Later, Joseph and Gschneider [209] determined the maximum solid solubility of $\mathrm{Mg}$ in $\alpha-\mathrm{Nd}$ as 8.2 at.\% $\mathrm{Mg}$ at the $824 \mathrm{~K}$ eutectoidal decomposition of $\beta$-Nd. Iandelli and Palenzona [210] determined the crystal structure of the intermediate compound $\mathrm{MgNd}$ as cubic with $c P 2-\mathrm{CsCl}$ type. The $\mathrm{Mg}_{2} \mathrm{Nd}$ was determined as $c F 24-\mathrm{Cu}_{2} \mathrm{Mg}$ type, $\mathrm{Mg}_{3} \mathrm{Nd}$ as $c F 16-\mathrm{BiF}_{3}$ type, $\mathrm{Mg}_{41} \mathrm{Nd}_{5}$ as $t I 92-\mathrm{Ce}_{5} \mathrm{Mg}_{41}$ type, and $\mathrm{Mg}_{12} \mathrm{Nd}$ as $t I 26-\mathrm{ThMn}_{12}$ type structures [211]. Nayeb-Hashemi and Clark [212] constructed the $\mathrm{Mg}-\mathrm{Nd}$ phase diagram based on the available data in the literature. According to their assessment, five intermetallic compounds, $\mathrm{MgNd}, \mathrm{Mg}_{2} \mathrm{Nd}, \mathrm{Mg}_{3} \mathrm{Nd}, \mathrm{Mg}_{41} \mathrm{Nd}_{5}$ and $\mathrm{Mg}_{12} \mathrm{Nd}$, 




FIgURE 17: Mg-Ce phase diagram.

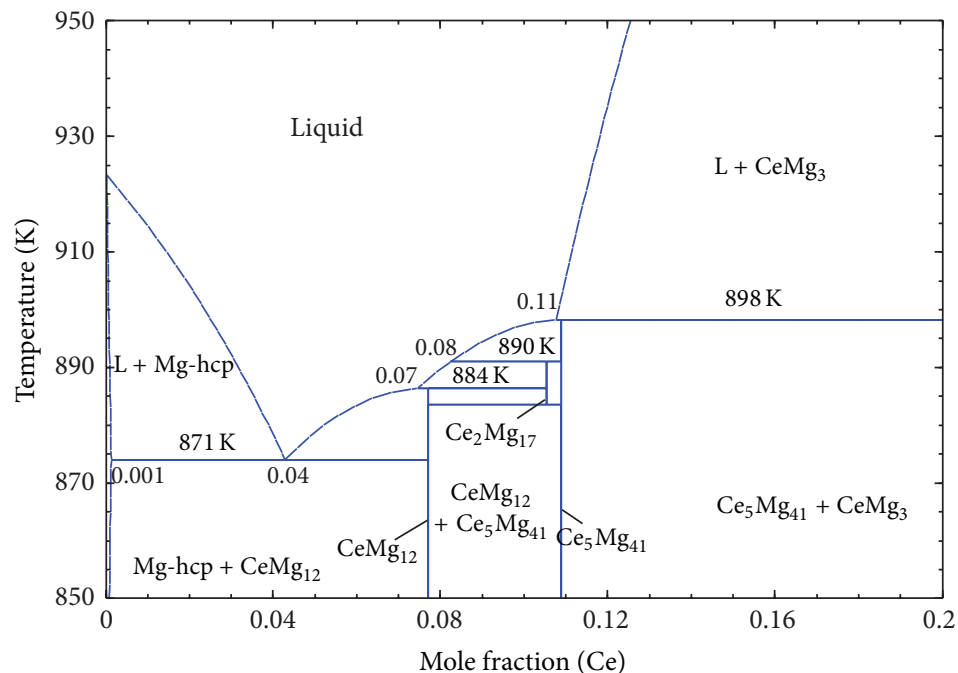

Figure 18: Magnified portion of the Mg-Ce phase diagram.



Figure 19: Calculated (a) enthalpy of mixing of liquid Mg-Ce at $1090 \mathrm{~K}: \square$ : [16] at $1002 \mathrm{~K}$, O: [16] at $1008 \mathrm{~K}$. (b) Activity of liquid Mg and Ni at $1100 \mathrm{~K}: \bigcirc:$ [72] at $1100 \mathrm{~K}, \triangle:$ [73] at $1092 \mathrm{~K}, \times:$ [74] at $1100 \mathrm{~K}$. (c) Heat capacity for the $\mathrm{MgNi}_{2}: \mathrm{O}:[16]$, $\square:$ [75]. (d) Enthalpy of formation of $\mathrm{Mg}_{2} \mathrm{Ni}$ and $\mathrm{MgNi}_{2}: \triangle:[74] ; \times:[76] ; \square:[77] ; *:[78]$. 
TABLE 23: Crystal structure data for Mg-Ce intermetallic compounds.

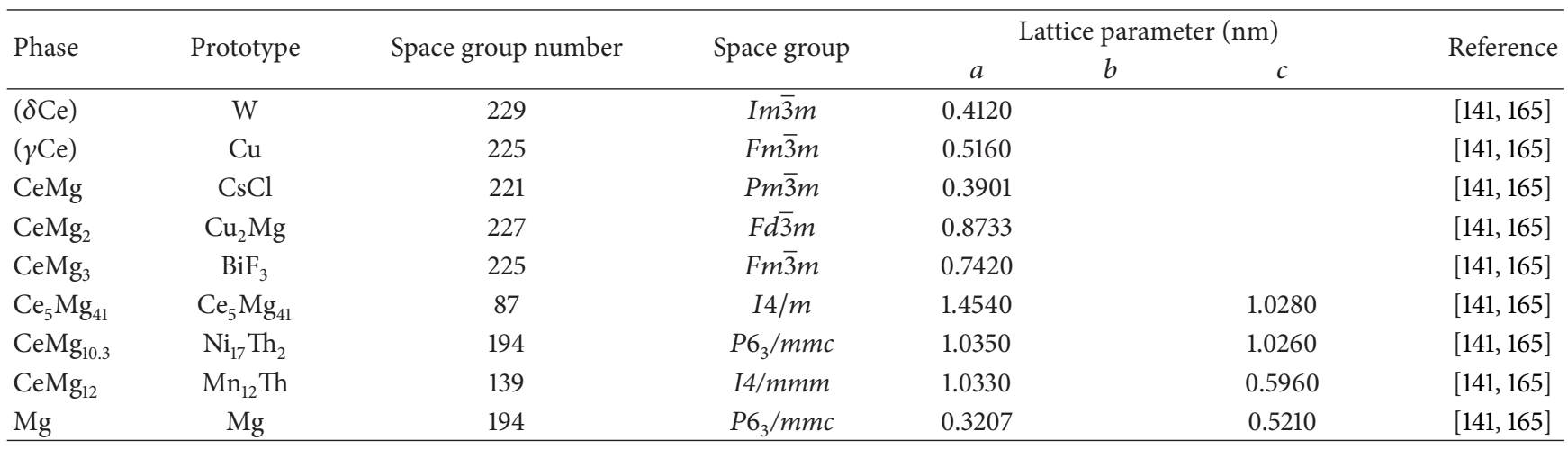

TABle 24: Optimized model parameters of the Mg-Ce system [42].

\begin{tabular}{|c|c|}
\hline Phase & $\begin{array}{c}\text { Parameters } \\
\Delta g^{0} \text { and }{ }^{0} L \text { in } J / \text { mole, }{ }^{\circ} \Delta H \text { in } J / \text { mole } \cdot \text { atom and } \\
{ }^{\circ} \Delta S \text { in } / / \text { mole.atom } \cdot \mathrm{K}\end{array}$ \\
\hline Liquid & $\begin{array}{c}\mathrm{Z}_{\mathrm{MgCe}}^{\mathrm{Mg}}=2, \mathrm{Z}_{\mathrm{CeMg}}^{\mathrm{Ce}}=6 ; \\
\Delta g_{\mathrm{MgCe}}^{0}=-15914.4+7.44 T ; \\
\Delta g_{\mathrm{MgCe}}^{10}=-9632.4+2.51 T ; \\
\Delta g_{\mathrm{MgCe}}^{01}=-8371.8\end{array}$ \\
\hline Mg-hcp & ${ }^{0} L^{\mathrm{Mg}-\mathrm{hcp}}=-24486.4$ \\
\hline$\delta-\mathrm{Ce}$ & ${ }^{0} L^{\delta \text {-Ce }}=-15600.7-9.75 T ;{ }^{1} L^{\delta \text {-Ce }}=-9003$ \\
\hline$\gamma$-Ce & ${ }^{0} L^{\gamma-\mathrm{Ce}}=-9277.0 T$ \\
\hline $\mathrm{CeMg}$ & ${ }^{\circ} \Delta H_{\mathrm{Ce}, \mathrm{Mg}}^{\mathrm{CeMg}}=-14300.0 ;{ }^{\circ} \Delta S_{\mathrm{Ce}, \mathrm{Mg}}^{\mathrm{CeMg}}=-2.52$ \\
\hline $\mathrm{CeMg}_{2}$ & ${ }^{\mathrm{o}} \Delta H_{\mathrm{Ce}, \mathrm{Mg}}^{\mathrm{CeMg}}=-15816.3{ }^{\circ}{ }^{\circ} \Delta S_{\mathrm{Ce}, \mathrm{Mg}}^{\mathrm{CeMg}}=-3.43$ \\
\hline $\mathrm{CeMg}_{3}$ & ${ }^{\circ} \Delta H_{\mathrm{Ce}, \mathrm{Mg}}^{\mathrm{CeMg}}=-19000.0 ;{ }^{\circ} \Delta S_{\mathrm{Ce}, \mathrm{Mg}}^{\mathrm{Ceeg}}=-6.62$ \\
\hline $\mathrm{Ce}_{5} \mathrm{Mg}_{41}$ & ${ }^{\circ} \Delta H_{\mathrm{Ce}, \mathrm{Mg}}^{\mathrm{Ce}_{5} \mathrm{Mg}_{41}}=-12521.8 ;{ }^{\circ} \Delta S_{\mathrm{Ce}, \mathrm{Mg}}^{\mathrm{Ce}_{5} \mathrm{Mg}_{41}}=-6.50$ \\
\hline $\mathrm{Ce}_{2} \mathrm{Mg}_{17}$ & ${ }^{\circ} \Delta H_{\mathrm{Ce}, \mathrm{Mg}}^{\mathrm{Ce}_{2} \mathrm{Mg}_{17}}=-11363.5 ;{ }^{\circ} \Delta S_{\mathrm{Ce}, \mathrm{Mg}}^{\mathrm{Ce}_{2} \mathrm{Mg}_{17}}=-5.40$ \\
\hline $\mathrm{CeMg}_{12}$ & ${ }^{\mathrm{o}} \Delta H_{\mathrm{Ce}, \mathrm{Mg}}^{\mathrm{CeMg}}=-10931.1 ;{ }^{\circ} \Delta S_{\mathrm{Ce}, \mathrm{Mg}}^{\mathrm{CeMg}}=-6.65$ \\
\hline
\end{tabular}

TABLE 25: Enthalpy of formation of the Mg-Ce intermetallic compounds.

\begin{tabular}{|c|c|c|c|}
\hline Compound & Enthalpy of formation (kJ/mole-atom) & Entropy of formation $(\mathrm{J} / \mathrm{mole} \cdot$ atom $\cdot \mathrm{K})$ & Reference \\
\hline \multirow{4}{*}{$\mathrm{CeMg}$} & -27.20 & & [168] Exp. \\
\hline & -13.08 & & [169] Exp. \\
\hline & -12.00 & & [162] Cal. [F.P.] \\
\hline & -14.30 & -2.52 & [42] Cal. (Calphad) \\
\hline \multirow{3}{*}{$\mathrm{CeMg}_{2}$} & -11.38 & & [169] Exp. \\
\hline & -11.20 & & [162] Cal. [F.P.] \\
\hline & -15.82 & -3.43 & [42] Cal. (Calphad) \\
\hline \multirow{5}{*}{$\mathrm{CeMg}_{3}$} & -17.78 & & [168] Exp. \\
\hline & -18.9 & & [169] Exp. \\
\hline & -14.93 & & {$[170]$} \\
\hline & -12.80 & & [162] Cal. [F.P.] \\
\hline & -19.0 & -6.62 & [42] Cal. (Calphad) \\
\hline \multirow{3}{*}{$\mathrm{Ce}_{5} \mathrm{Mg}_{41}$} & -18.13 & & [169] Exp. \\
\hline & -7.00 & & [162] Cal. [F.P.] \\
\hline & -12.52 & -6.50 & [42] Cal. (Calphad) \\
\hline $\mathrm{Ce}_{2} \mathrm{Mg}_{17}$ & -11.36 & -5.40 & [42] Cal. (Calphad) \\
\hline \multirow{2}{*}{$\mathrm{CeMg}_{12}$} & -14.09 & & [169] Exp. \\
\hline & -10.93 & -6.65 & [42] Cal. (Calphad) \\
\hline
\end{tabular}


TABLE 26: Crystal structure data for Mg-Nd intermetallic compounds.





Figure 20: Mg-Nd phase diagram [116].

along with terminal solid solutions of $\mathrm{Nd}$ in $\mathrm{Mg}, \mathrm{Mg}$ in $\alpha-\mathrm{Nd}$, and $\mathrm{Mg}$ in $\beta-\mathrm{Nd}$ exist in the $\mathrm{Mg}-\mathrm{Nd}$ phase diagram. Afterwards, Delfino et al. [211] studied this system using Xray, DTA, metallography, and SEM analysis. According to them [211], $\mathrm{Mg}_{2} \mathrm{Nd}$ is a metastable compound because it was only observed in the samples quenched directly from liquid and not in the annealed ones. Later, Gorsse et al. [213] also reported $\mathrm{Mg}_{2} \mathrm{Nd}$ as a metastable compound based on their microstructural analysis. $\mathrm{Mg}_{41} \mathrm{Nd}_{5}$ has been found as the $\mathrm{Mg}$ richest stable phase by Delfino et al. [211]. They also suggested small solubility for $\mathrm{MgNd}$. In addition they reported $\mathrm{Mg}_{3} \mathrm{Nd}$ with maximum solubility of 6 at. $\%$ at $833 \mathrm{~K}$ extending towards the Mg-rich side. Pahlman and Smith [169] determined the vapor pressure of $\mathrm{Mg}$ in $\mathrm{Mg}-\mathrm{Nd}$ alloys in the temperature range $650-930 \mathrm{~K}$ by the knudsen effusion technique. Ogren et al. [214] determined the enthalpy of formation of $\mathrm{MgNd}$ compound.

Thermodynamic modeling on the $\mathrm{Mg}-\mathrm{Nd}$ system has been carried out by Gorsse et al. [213] who considered the $\mathrm{Mg}$ activities obtained from vapour pressure data of Pahlman and Smith [169]. However, in their assessment, the intermediate compounds $\mathrm{MgNd}, \mathrm{Mg}_{2} \mathrm{Nd}, \mathrm{Mg}_{3} \mathrm{Nd}$, and $\mathrm{Mg}_{41} \mathrm{Nd}_{5}$ were treated as stoichiometric compounds. Guo and Du [215], Meng et al. [216], and Qi et al. [217] also made thermodynamic assessments on this system. Guo and Du
[215] used Sublattice models to reproduce the homogeneity range of the intermetallic compounds: $\mathrm{MgNd} \mathrm{Mg}_{3} \mathrm{Nd}$, and $\mathrm{Mg}_{41} \mathrm{Nd}_{5}$. Recently, Kang et al. [171] assessed all the previous optimizations and reoptimized this system using Modified quasichemical model. They [171] also employed first principle calculations to predict the heat of formation of the intermetallic compounds which are in fair agreement with the reported values by Tao et al. [162]. The crystallographic information of the intermetallic compounds is listed in Table 26. The phase diagram in Figure 20 has been calculated using the FTlight database [116]. The enthalpies and entropies of formation of the intermetallic compounds on the $\mathrm{Mg}-\mathrm{Nd}$ system are listed in Table 27.

\section{Mg-Cu (Magnesium-Copper)}

Three very old assessments dating back to 1900s, on the $\mathrm{Mg}-\mathrm{Cu}$ phase equilibria by Boudouard [218], Sahmen [219] and Urazov [220], could be found in the literature. The existence of two congruently melting compounds $\left(\mathrm{Mg}_{2} \mathrm{Cu}\right.$ and $\mathrm{MgCu}_{2}$ ) and three eutectic points were reported in those works. But the most extensive work on the $\mathrm{Mg}-\mathrm{Cu}$ system was done by Jones [221] in 1931 using both thermal and microscopic analyses. His reported data were not fully consistent with the previous authors [218-220]. Since he used 
TABLE 27: Enthalpy and entropy of formation of the Mg-Nd intermetallic compounds.

\begin{tabular}{|c|c|c|c|}
\hline Compound & Enthalpy of formation (kJ/mole.atom) & Entropy of formation $(\mathrm{J} / \mathrm{mole} \cdot \mathrm{atom} \cdot \mathrm{K})$ & Reference \\
\hline \multirow{3}{*}{$\mathrm{Mg}_{41} \mathrm{Nd}_{5}$} & $-17.99 \pm 1.34$ & $5.86 \pm 1.80$ & [169] Exp. \\
\hline & -5.90 & & [162] Cal. (F.P.) \\
\hline & -24.61 & & [171] Cal. (F.P.) \\
\hline \multirow{2}{*}{$\mathrm{Mg}_{3} \mathrm{Nd}$} & $-18.74 \pm 1.42$ & $5.15 \pm 1.88$ & [169] Exp. \\
\hline & -11.70 & & [162] Cal. (F.P.) \\
\hline \multirow{2}{*}{$\mathrm{Mg}_{2} \mathrm{Nd}$} & $-18.66 \pm 1.42$ & $6.32 \pm 1.88$ & [169] Exp. \\
\hline & -9.60 & & [162] Cal. (F.P.) \\
\hline \multirow{2}{*}{$\mathrm{MgNd}$} & $-13.89 \pm 1.55$ & $4.02 \pm 2.05$ & [169] Exp. \\
\hline & -11.00 & & [162] Cal. (F.P.) \\
\hline
\end{tabular}

huge number of samples and extreme precautions during the sample preparations his data were more reliable.

$\mathrm{Mg}_{2} \mathrm{Cu}$ does not have any solid solubility. However, $\mathrm{MgCu}_{2}$ shows temperature dependent solubility range. Grime and Morris-Jones [222] reported a homogeneity range of 2 to 3 at.\% on both sides of the $\mathrm{MgCu}_{2}$ stoichiometry. Also, X-ray diffraction from Sederman [223] disclosed that the extension of solubility on both sides of $\mathrm{MgCu}_{2}$ at $773 \mathrm{~K}$ should not exceed 2.55 at.\% (from 64.55 to 67.20 at.\% $\mathrm{Cu}$ ) and considerably less at lower temperatures. However Xray diffraction, microscopic, simple, and differential thermal analysis by Bagnoud and Feschotte [193] confirmed that the maximum solid solubilities at the eutectic temperatures on both sides of $\mathrm{MgCu}_{2}$ are 64.7 and 69 at.\% Cu.

Limited terminal solubility of $\mathrm{Cu}$ in $\mathrm{Mg}$ as well as $\mathrm{Mg}$ in $\mathrm{Cu}$ has been reported in different assessments. Hansen [224] showed that the solubility of $\mathrm{Cu}$ in $\mathrm{Mg}$ increases from about 0.1 at.\% $\mathrm{Cu}$ at room temperature to about 0.4-0.5 at.\% $\mathrm{Cu}$ at $758 \mathrm{~K}$. However, elaborate metallographic analysis of Jones [221] showed that the solubility of $\mathrm{Cu}$ in $\mathrm{Mg}$ is only 0.007 at. $\% \mathrm{Cu}$ at room temperature, increasing to about 0.012 at. $\% \mathrm{Cu}$ near the eutectic temperature. These values are contradictory to those given by Hansen [224]. Later, Stepanov and Kornilov [225] revealed that the solubility is 0.2 at.\% Cu at $573 \mathrm{~K}, 0.3$ at. $\% \mathrm{Cu}$ at $673 \mathrm{~K}$, and 0.55 at.\% Cu at $753 \mathrm{~K}$. This is in considerable agreement with the metallographic work of Hansen [224]. However considering the accuracy of the analysis of Jones [221], it appears that the solubility limits given by $[224,225]$ are quite high. On the other hand, quite large solubility of $\mathrm{Mg}$ in $\mathrm{Cu}$ has been found. According to Grime and Morris-Jones [222], the maximum solubility is approximately 7.5 at. $\% \mathrm{Mg}$, whereas, Jones [221] reported that this solubility is about 5.3 at. $\% \mathrm{Mg}$ at $773 \mathrm{~K}$, increasing to about 6.3 at.\% Mg at 1003 K. Stepanov and Kornilov [225], however, determined the maximum solid solubility of 10.4 at.\% Mg using an electrical resistance method. Bagnoud and Feschotte [193] placed the maximum solubility at 6.94 at.\% Mg. With the exception of Stepanov and Kornilov [225] most of these data $[193,221,222]$ are in close agreement with each other.

The vapor pressures of $\mathrm{Mg}$ over $\mathrm{Mg}-\mathrm{Cu}$ liquid were measured by Garg et al. [120], Schmahl and Sieben [121], Juneja et al. [119], and Hino et al. [122]. All these results are in close agreement with each other. Enthalpy of mixing for the $\mathrm{Mg}-\mathrm{Cu}$ liquid was measured by Sommer et al. [117] and Batalin et al. [118] using calorimetric method. King and Kleppa [77] determined the enthalpies of formation of $\mathrm{MgCu}_{2}$ and $\mathrm{Mg}_{2} \mathrm{Cu}$ by calorimetric method. Similar values have been determined by Eremenko et al. [123] using EMF measurements. The vapor pressure measurements of Smith and Christian [76] showed discrepancy with the other results. Due to different measurement techniques, the reported values are contradictory to one another.

Several thermodynamic assessments on the $\mathrm{Mg}-\mathrm{Cu}$ system have been carried out by Nayeb-Hashemi and Clark [226], Coughanowr et al. [227], Zuo and Chang [228]. The latest assessment on this system was published by MezbahulIslam et al. [66] who considered the presence of short range ordering in the liquid. The $\mathrm{Mg}-\mathrm{Cu}$ phase diagram and some of the thermodynamic properties have been calculated as shown in Figures 21 and 22, based on their optimized parameters as listed in Table 29. Also, the crystallographic data of the $\mathrm{Mg}-\mathrm{Cu}$ intermetallics are listed in Table 28. Mashovets and Puchkov [59] used modified quasichemical model for describing the liquid and also their phase diagram and thermodynamic properties showed very good agreement with the available experimental data. The enthalpies and entropies of formation of $\mathrm{Mg}_{2} \mathrm{Cu}$ and $\mathrm{MgCu}_{2}$ are listed in Table 30.

\section{Mg-Sn (Magnesium-Tin)}

The Mg-Sn phase diagram has been studied by many researchers. The liquid near the $\mathrm{Mg}$-rich side of the $\mathrm{Mg}$-Sn system has been investigated by Grube [229], Kurnakow and Stepanow [230], Hume-Rothery [231] and Raynor [232] using thermal analysis. Nayak and Oelsen $[233,234]$ also measured the same using a calorimetric analysis. These results are fairly in agreement with each other. The liquidus curve near $\mathrm{Mg}_{2} \mathrm{Sn}$ was determined by several researchers [229-236] and the melting point of $\mathrm{Mg}_{2} \mathrm{Sn}$ was reported as $1043 \mathrm{~K} \pm$ (8 to 25). The Sn-rich liquidus curve was first measured by Heycock and Neville [237] and later on by other investigators [229, 231, 233, 234, 238, 239]. Hume-Rothery [231] reported a hump in this side of the liquidus curve and interpreted it as a slight 


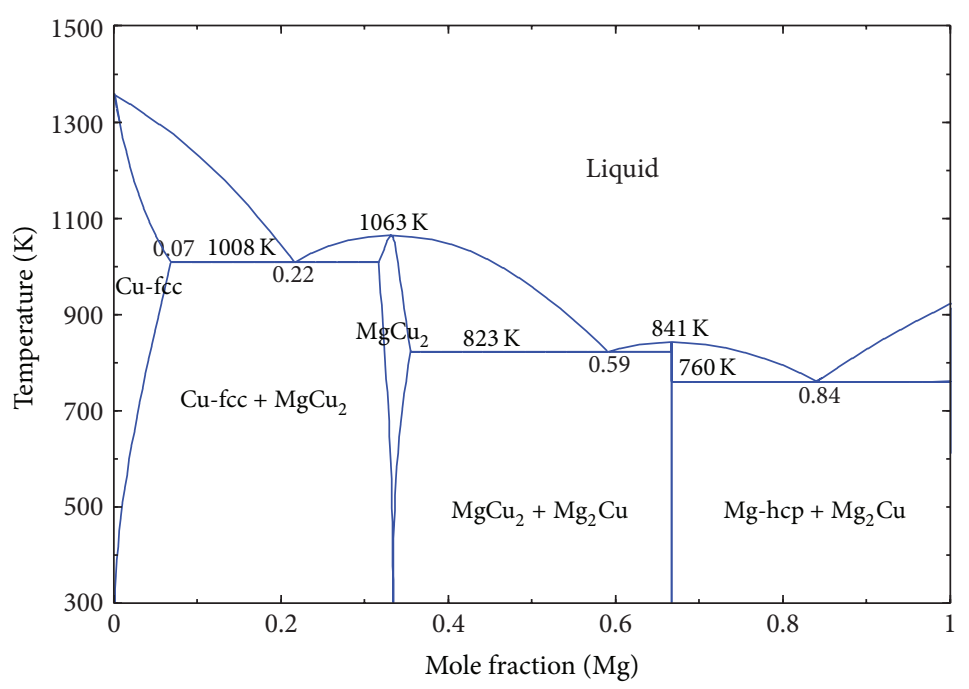

Figure 21: Mg-Cu phase diagram [66].

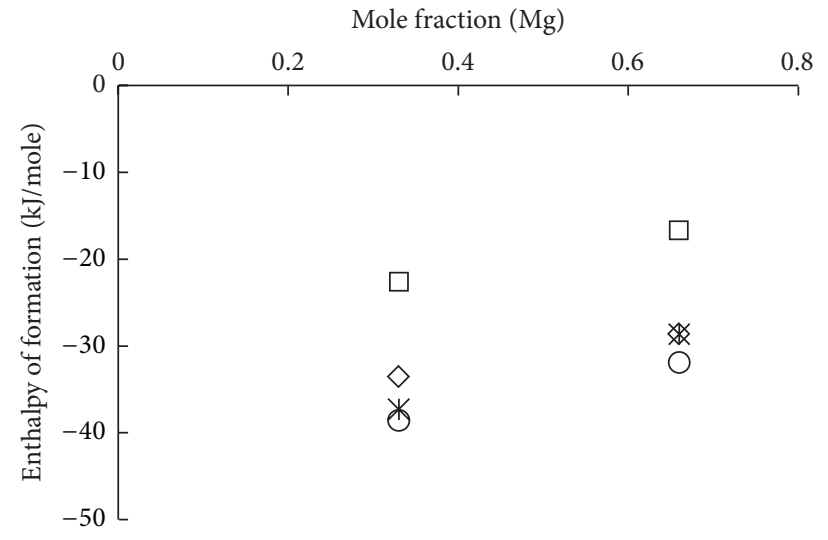

(a)

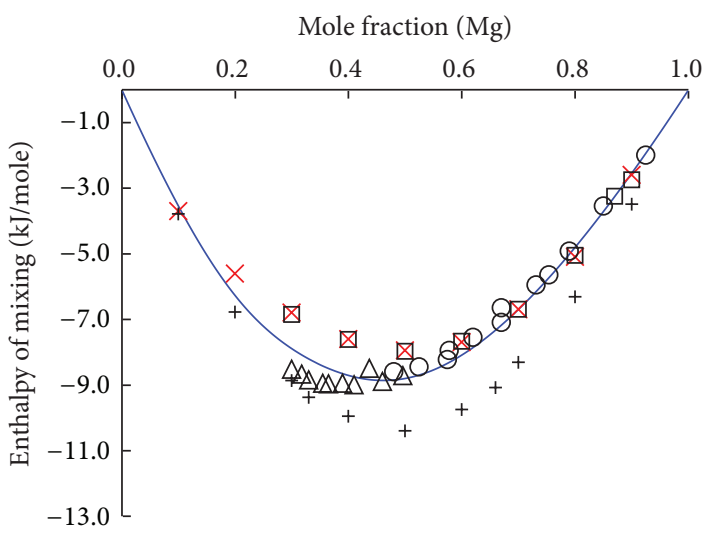

(b)

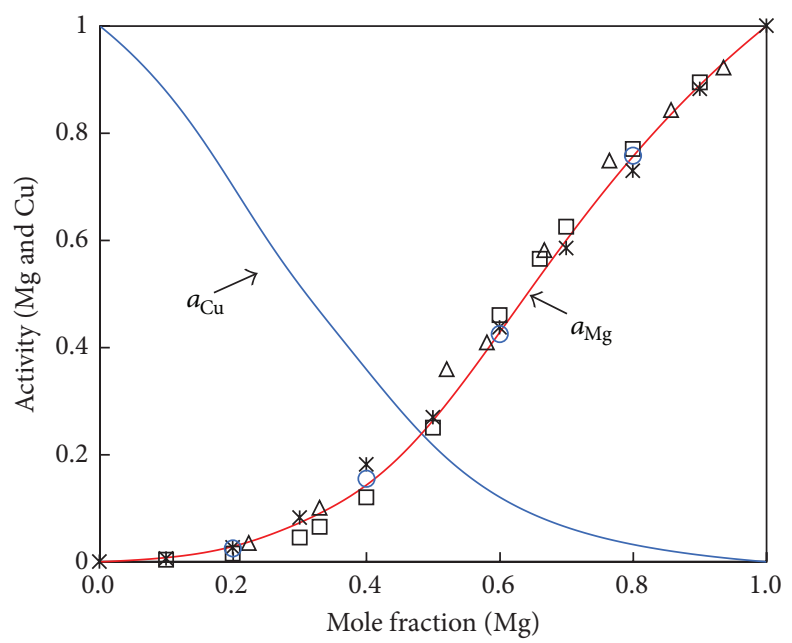

(c)

Figure 22: (a) Calculated enthalpy of mixing of Mg-Cu liquid at $1400 \mathrm{~K}$ [66]: $\square$ : [117] at $1100 \mathrm{~K}, \triangle$ : [117] at 1120 K, O: [117] at 1125 K, $\times$ : [118] at $1100 \mathrm{~K},+:$ [119] at $1100 \mathrm{~K}$. (b) Activity of Mg in the Mg-Cu liquid at $1123 \mathrm{~K}: *:[120]$ at $1100 \mathrm{~K}, \triangle:$ [121] at $1123 \mathrm{~K}, \square:[119]$ at $1100 \mathrm{~K}, \mathrm{O}:[122]$ at $1100 \mathrm{~K}$. (c) Heat of formation of the stoichiometric compounds: $*:$ [66], $\diamond:$ [77], $\bigcirc:[123], \square:[76]$. 
TABle 28: Crystal structure data for $\mathrm{Mg}$-Cu intermetallic compounds.

\begin{tabular}{|c|c|c|c|c|c|c|c|}
\hline \multirow{2}{*}{ Phase } & \multirow{2}{*}{ Prototype } & \multirow{2}{*}{ Space group number } & \multirow{2}{*}{ Space group } & \multicolumn{3}{|c|}{ Lattice parameter (nm) } & \multirow{2}{*}{ Reference } \\
\hline & & & & $a$ & $b$ & $c$ & \\
\hline $\mathrm{Mg}_{2} \mathrm{Cu}$ & $\mathrm{Mg}_{2} \mathrm{Cu}$ & 70 & Fddd & 0.5283 & 0.9062 & 1.8351 & {$[137]$} \\
\hline $\mathrm{MgCu}_{2}$ & $\mathrm{MgCu}_{2}$ & 227 & $F d \overline{3} m$ & 0.7031 & 0.7031 & 0.7031 & [137] \\
\hline
\end{tabular}

TABLE 29: Optimized model parameters for the Mg-Cu system [66].

\begin{tabular}{|c|c|}
\hline Phase & $\begin{array}{c}\text { Parameters } \\
\Delta g^{0} \text { and }{ }^{0} L \text { in } \mathrm{J} / \mathrm{mole}\end{array}$ \\
\hline Liquid & $\begin{array}{c}\mathrm{Z}^{\mathrm{Mg}}{ }_{\mathrm{MgCu}}=4, \mathrm{Z}_{\mathrm{CuMg}}^{\mathrm{Cu}}=2 ; \\
\Delta g_{\mathrm{MgCu}}^{0}=-12975.95 \\
\Delta g_{\mathrm{MgCu}}^{10}=-6153.13+1.26 T ; \\
\Delta g_{\mathrm{MgCu}}^{01}=-13528.50\end{array}$ \\
\hline Mg-hcp & ${ }^{0} L^{\mathrm{Mg}-\mathrm{hcp}}=8371.60$ \\
\hline $\mathrm{Cu}-\mathrm{fcc}$ & ${ }^{0} L^{\mathrm{Cu}-\mathrm{fcc}}=-21923.39+5.37 T$ \\
\hline $\mathrm{Mg}_{2} \mathrm{Cu}$ & $\Delta G_{f}=-28620.0+0.03 T$ \\
\hline $\begin{array}{l}\mathrm{MgCu}_{2} \\
(\mathrm{Mg} \%, \mathrm{Cu}) \\
(\mathrm{Cu} \%, \mathrm{Mg})_{2}\end{array}$ & $\begin{array}{c}{ }^{0} G_{\mathrm{Cu}: \mathrm{Cu}}^{\mathrm{MgCu}_{2}}=16743.20 ;{ }^{0} G_{\mathrm{Mg}: \mathrm{Mg}}^{\mathrm{MgCu}_{2}}=-37684.26 ; \\
{ }^{0} G_{\mathrm{Cu}: \mathrm{Mg}}^{\mathrm{MgCu}_{2}}=0 ;{ }^{0} G_{\mathrm{Mg}: \mathrm{Mg}}^{\mathrm{MgCu}_{2}}=6278.7 ; \\
{ }^{0} L_{\mathrm{Mg}, \mathrm{Cu} C \mathrm{Cu}}^{\mathrm{MgCu}}={ }^{0} L_{\mathrm{Mg}, \mathrm{Cu}: \mathrm{Mg}}^{\mathrm{MgCu}_{2}}=13011.35 ; \\
{ }^{0} L_{\mathrm{Cu}: \mathrm{Mg}, \mathrm{Cu}}^{\mathrm{MgCu}}={ }^{0} L_{\mathrm{Mg}: \mathrm{Mg}, \mathrm{Cu}}^{\mathrm{MgCu}}=6599.45 ;\end{array}$ \\
\hline
\end{tabular}

liquid immiscibility. However, the other investigators [230, 233, 234, 237-239] did not confirm this phenomenon.

The $(\mathrm{Mg})$ solidus curve was determined by Grube and Vosskuhler [240] and Vosskuhler [241] using resistivity technique, by Raynor [232] using metallography and by Nayak and Oelsen [234] using calorimeter. The solid solubility of $\mathrm{Sn}$ in $\mathrm{Mg}$ was reported by Stepanow [242] and Gann [243] and later by Grube and Vosskuhler [240], Vosskuhler [241], Raynor [232], Nayak and Oelsen [234] and Nishinura and Tanaka [244] by different methods. According to NayebHashemi and Clark [239] the solid solubility of $\mathrm{Mg}$ in $\mathrm{Sn}$ is infinitesimally small. Eldridge et al. [245] and Caulfield and Hudson [246] reported a very narrow solid solubility range of $\mathrm{Mg}$ and $\mathrm{Sn}$ in $\mathrm{Mg}_{2} \mathrm{Sn}$ at high temperature (few tenth of a percent [245] to 0.5 at\% [246]).

Kawakami [25], Sommer [172] and Nayak and Oelsen $[173,247]$ measured the heat of mixing of the Mg-Sn liquid using calorimetric method, whereas Eremenko and Lukashenko [248], Steiner et al. [235], Eldridge et al. [245] and Sharma [127] calculated it from the EMF measurement. The heat of formation of the Mg-Sn solid was determined by Kubaschewski [249], Nayak and Oelsen [173], Sharma [127], Beardmore et al. [174], kBiltz and Holverscheit [250], Ashtakala and Pidgeon [251] and Borsese et al. [175], whereas Dobovisek and Paulin [176] calculated heat of formation of the $\mathrm{Mg}_{2} \mathrm{Sn}$ compound using the Pauling's rule. The heat capacity of the $\mathrm{Mg}_{2} \mathrm{Sn}$ compound was determined by Jelinek et al. [252] at low temperature (up to $300 \mathrm{~K}$ ), whereas Chen et al. [253] determined the same at much higher temperature $(300-700 \mathrm{~K})$.

The phase equilibrium and experimental phase diagram data are reviewed by Nayeb-Hashemi and Clark [239]. Higher negative heat of formation values of $\mathrm{Mg}_{2} \mathrm{Sn}$ were reported by Sharma [127], Eldridge et al. [245] and Biltz and Holverscheit [250] than those by Nayeb-Hashemi and Clark [239]. NayebHashemi and Clark [239] along with others like Egan [254], Eckert et al. [255], Pavlova and Poyarkov [256] optimized the phase diagram using measured thermodynamic data. Very recently, Jung and Kim [257], Meng et al. [258] and Kang and Pelton [259] optimized the same system and modeled the liquid phase by the MQM. They considered the thermodynamic data reviewed by Nayeb-Hashemi and Clark [239]. The most recent optimization has been performed by Ghosh et al. [22] who critically reviewed all the work done prior to them and reported a more accurate description of the $\mathrm{Mg}-\mathrm{Sn}$ system. The crystal structure information and thermodynamic modeling parameters are listed in Tables 31 and 32. Figures 23 and 24 show the $\mathrm{Mg}$-Sn phase diagram as well as some of the thermodynamic properties of the liquid. The enthalpy and entropy of formation of $\mathrm{Mg}_{2} \mathrm{Sn}$ are listed in Table 33.

\section{Summary}

Eleven essential Mg-based binary systems have been reviewed in this paper. All the available experimental data has been summarized and assessed critically to provide detailed understanding of each system. The phase diagrams are calculated based on the most up-to-date optimized parameters. Critical information of the phase diagram both as composition and temperature is shown on the figures. All the binary systems have been modeled using the modified quasichemical model which is the only scientific model that accounts for the short range ordering 
TABle 30: Enthalpy and entropy of formation of the $\mathrm{Mg}$-Cu intermetallic compounds.

\begin{tabular}{|c|c|c|c|}
\hline Compound & $\begin{array}{c}\text { Enthalpy of formation } \\
(\mathrm{kJ} / \mathrm{mole} \cdot \text { atom })\end{array}$ & $\begin{array}{c}\text { Entropy of formation } \\
(\mathrm{J} / \mathrm{mole} \cdot \text { atom } \cdot \mathrm{K})\end{array}$ & Reference \\
\hline \multirow{5}{*}{$\mathrm{Mg}_{2} \mathrm{Cu}$} & -9.54 & -0.01 & [66] Cal. (Calphad) \\
\hline & $-5.58 \pm 2.51$ & $9.49 \pm 5.02$ & [76] Exp. \\
\hline & $-10.63 \pm 1.09$ & $-1.49 \pm 1.38$ & [123] Exp. \\
\hline & $-9.55 \pm 0.42$ & & [77] Exp. \\
\hline & $-9.8 \pm 1.8$ & & [16] Exp. \\
\hline \multirow{6}{*}{$\mathrm{MgCu}_{2}$} & -12.56 & 0.0 & [66] Cal. (Calphad) \\
\hline & $-7.5 \pm 1.53$ & $3.91 \pm 2.09$ & [76] Exp. \\
\hline & $-12.85 \pm 0.67$ & $0.42 \pm 0.84$ & [123] Exp. \\
\hline & $-11.18 \pm 0.42$ & & [77] Exp. \\
\hline & -4.75 & & [71] Cal. (F.P.) \\
\hline & $-12.7 \pm 2.0$ & & [16] Exp. \\
\hline
\end{tabular}

TABLE 31: Crystal structure data for Mg-Sn intermetallic compound.

\begin{tabular}{lccccccc}
\hline \multirow{2}{*}{ Phase } & \multirow{2}{*}{ Prototype } & Space group number & Space group & \multicolumn{3}{c}{ Lattice parameter (nm) } \\
& & & & $a$ & $b$ & $c$ \\
\hline $\mathrm{Mg}_{2} \mathrm{Sn}$ & $\mathrm{CF}_{2}$ & 225 & $F m \overline{3} m$ & 0.6760 & 0.6760 & 0.6760 \\
\hline
\end{tabular}

TABLE 32: Optimized model parameters for the Mg-Sn system [22].

\begin{tabular}{|c|c|}
\hline Phase & $\begin{array}{c}\text { Parameters } \\
\Delta g^{0} \text { and }{ }^{0} L \text { in } J / \text { mole, }{ }^{\circ} \Delta H \text { in } J / \text { mole } \cdot \text { atom and } \\
{ }^{\circ} \Delta S \text { in } / / \text { mole } \cdot \text { atom } \cdot \mathrm{K}\end{array}$ \\
\hline Liquid & $\begin{array}{c}\mathrm{Z}_{\mathrm{MgSn}}^{\mathrm{Mg}}=3, \mathrm{Z}_{\mathrm{SnMg}}^{\mathrm{Sn}}=6 ; \\
\Delta g_{\mathrm{MgSn}}^{0}=-17819.7-4.10 T ; \Delta g_{\mathrm{MgSn}}^{10}=1171.5 ; \\
\Delta g_{\mathrm{MgSn}}^{01}=-4184.0-2.09 \mathrm{~T}\end{array}$ \\
\hline Mg-hcp & $\begin{array}{c}{ }^{0} L^{\text {Mg-hcp }}=-62000 \\
{\left[{ }^{\circ} G^{\text {Sn-hcp }}={ }^{\circ} G^{\text {Sn-bct }}+5000\right]}\end{array}$ \\
\hline $\mathrm{Cu}-\mathrm{fcc}$ & $\begin{array}{c}{ }^{0} L^{\text {Sn-bct }}=-20000 \\
{\left[{ }^{\circ} G^{\mathrm{Mg}-\mathrm{bct}}={ }^{\circ} G^{\mathrm{Mg}-\mathrm{hcp}}+8360\right]}\end{array}$ \\
\hline $\mathrm{Mg}_{2} \mathrm{Sn}$ & ${ }^{\circ} \Delta H_{\mathrm{Sn}, \mathrm{Mg}}^{\mathrm{SnMg}_{2}}=-28332.9 ;^{\circ} \Delta S_{\mathrm{Sn}, \mathrm{Mg}}^{\mathrm{SnMg}_{2}}=-1.59$ \\
\hline
\end{tabular}

TABLE 33: Enthalpy and entropy of formation of $\mathrm{Mg}_{2} \mathrm{Sn}$.

\begin{tabular}{lcc}
\hline $\begin{array}{l}\text { Enthalpy of formation } \\
(\mathrm{kJ} / \mathrm{mole} \cdot \text { atom })\end{array}$ & $\begin{array}{c}\text { Entropy of formation } \\
(\mathrm{J} / \mathrm{mole} \cdot \text { atom } \cdot \mathrm{K})\end{array}$ & Reference \\
\hline-28.33 & -1.59 & [22] Cal. (Calphad) \\
-8.47 & & {$[172]$ Exp. } \\
-7.40 & {$[173]$ Exp. } \\
-9.30 & {$[127]$ Exp. } \\
-8.97 & {$[174]$ Exp. } \\
-8.17 & {$[175]$ Exp. } \\
-10.75 & {$[176]$ Exp. } \\
\hline
\end{tabular}

in the liquid. Reoptimization of the Mg-Y system has been performed to comply with the recent experimental data on the homogeneity range of the intermetallic compounds. The Mg-Nd phase diagram has been calculated using the FTlight database and its thermodynamic parameters are not available. The thermodynamic model parameters for all other systems have been summarized. These parameters are important for further development of the alloys into the multicomponent systems. The available thermodynamic properties for these binary systems have been calculated 




Figure 23: Mg-Sn phase diagram [22].

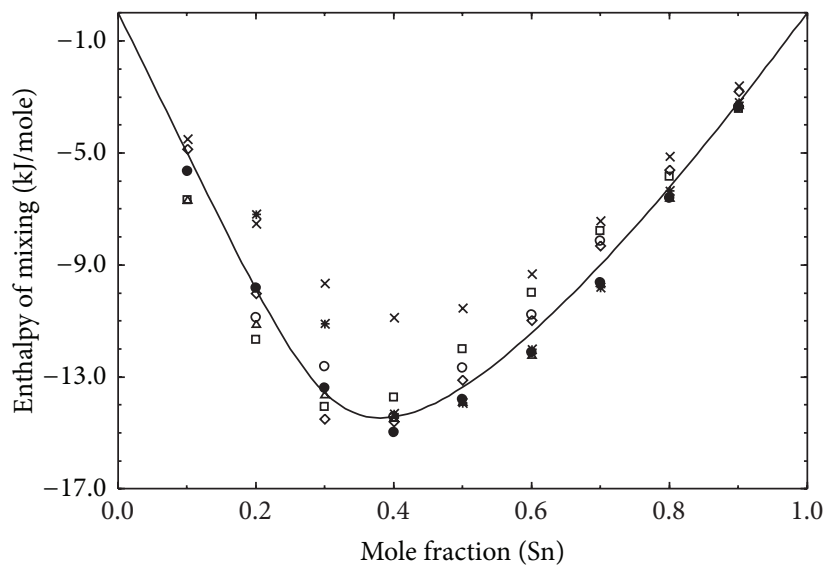

(a)

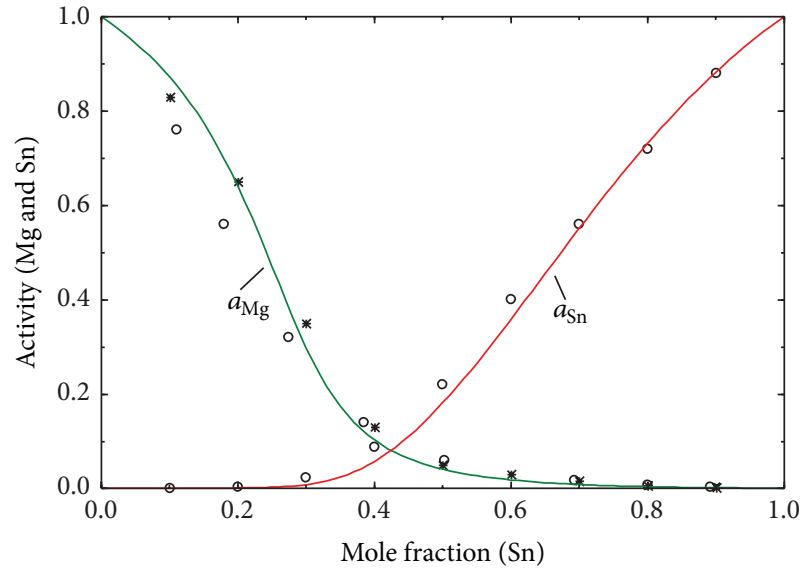

(b)

Figure 24: (a) Calculated enthalpy of mixing of Mg and Sn in the Mg-Sn liquid at $1073 \mathrm{~K}:$ o: [25], $\square:$ [124], $\triangle:$ [125], ๑: [126], *: [127], $\times:$ [128], $\diamond:$ [61]; (b) calculated activities of liquid Mg and Sn at $1073 \mathrm{~K}$ : o: [127], *: [124].

and compared with the experimental data for better understanding. The crystallographic data which is one of the primary requirements for Sublattice modeling is also provided in detail for all the binary systems. In addition heat of formation of the intermetallic compounds for each system obtained from experimental, first principle calculations and CALPHAD optimizations are provided. This paper will provide a much needed summarization of all the essential Mg alloys.

\section{Conflict of Interests}

The authors declare that there is no conflict of interests regarding the publication of this paper.

\section{References}

[1] R. Gradinger and P. Stolfig, "Magnesium wrought alloys for automotive applications," in Proceedings of the Minerals, Metals \& Materials Society, pp. 231-236, March 2003.

[2] M. O. Pekguleryuz, E. Baril, P. Labelle, and D. Argo, "Creep resistant Mg-Al-Sr alloys," Journal of Advanced Materials, vol. 35, no. 3, pp. 32-38, 2003.

[3] H. Mao, J. Brevick, C. Mobley et al., "Microstructural characteristics of die cast AZ91D and AM60 magnesium alloys," SAE Technical Paper, 1999.

[4] B. Zberg, P. J. Uggowitzer, and J. F. Löffler, "MgZnCa glasses without clinically observable hydrogen evolution for biodegradable implants," Nature Materials, vol. 8, no. 11, pp. 887-891, 2009. 
[5] E. Ma and J. Xu, "Biodegradable alloys: the glass window of opportunities," Nature Materials, vol. 8, no. 11, pp. 855-857, 2009.

[6] E. Aghion, B. Bronfin, F. von Buch, S. Schumann, and H. Friedrich, "Dead sea magnesium alloys newly developed for high temperature applications," in Proceedings of the Minerals, Metals \& Materials Society, pp. 177-182, March 2003.

[7] B. Mark, "Remarkable magnesium: the 21st century structural alloy for small components," White Paper, FisherCast Global Corporation, 2013.

[8] A. Boby, U. Pillai, B. Pillai, and B. Pai, "Developments in magnesium alloys for transport applications-an overview," Indian Foundry Journal, vol. 57, pp. 29-37, 2011.

[9] Z. Yanga, J. X. Zhang, G. W. Lorimer, and J. Robson, "Review on research and development of magnesium alloys," Acta Metallurgica Sinica (English Letters), vol. 21, pp. 313-328, 2008.

[10] R. Agarwal and F. Sommer, "Calorimetric measurements of liquid aluminum-magnesium alloys," Zeitschrift für Metallkunde, vol. 82, pp. 118-120, 1991.

[11] Z. Moser, W. Zakulski, K. Rzyman et al., "New thermodynamic data for liquid Aluminum-Magnesium alloys from emf, vapor pressures, and calorimetric studies," Journal of Phase Equilibria, vol. 19, no. 1, pp. 38-47, 1998.

[12] Y. J. Bhatt and S. P. Garg, "Thermodynamic study of liquid aluminum-magnesium alloys by vapor pressure measurements," Metallurgical Transactions B, vol. 7, no. 2, pp. 271-275, 1976.

[13] G. R. Belton and Y. K. Rao, "Galvanic cell study of activities in magnesium-aluminum liquid alloys," Transactions of the AIME, vol. 245, no. 10, pp. 2189-2193, 1969.

[14] J. M. Juneja, K. P. Abraham, and G. N. K. Iyengar, "Thermodynamic study of liquid magnesium-aluminium alloys by vapour pressure measurement using the boiling point method," Scripta Metallurgica, vol. 20, no. 2, pp. 177-180, 1986.

[15] V. P. Kazimirov and G. I. Batalin, "Calculation of thermodynamic properties of aluminum-magnesium melts by the pseudopotential method," Ukrainskii Khimicheskii Zhurnal, vol. 49 , no. 8, pp. 887-888, 1983.

[16] H. Feufel and F. Sommer, "Thermodynamic investigations of binary liquid and solid CuMg and $\mathrm{MgNi}$ alloys and ternary liquid CuMgNi alloys," Journal of Alloys and Compounds, vol. 224, no. 1, pp. 42-54, 1995.

[17] E. E. Lukashenko and A. M. Pogodaev, "Thermodynamics of magnesium-aluminum molten alloys," Izvestiya Akademii Nauk SSSR, Metally, pp. 91-96, 1971.

[18] V. N. Eremenko and G. M. Lukashenko, "Thermodynamic properties of liquid solutions in the magnesium-aluminum system," Ukrainskii Khimicheskii Zhurnal (Russian Edition), vol. 28, pp. 462-466, 1962.

[19] A. Schneider and E. K. Stoll, "Metal vapor pressure. I. Vapor pressure of magnesium over aluminum-magnesium alloys," Zeitschrift fur Angewandte Physik Und Chemie, vol. 47, pp. 519526, 1941.

[20] M. Y. Vyazner, A.G. Morachevskii, and A. Y. U. Taits, “Thermodynamic properties of magnesium-aluminum system molten alloys," Zhurnal Prikladnoi Khimii, vol. 44, no. 5, pp. 722-726, 1971.

[21] B. L. Tiwari, "Thermodynamic properties of liquid aluminummagnesium alloys measured by the emf method," Metallurgical and Materials Transactions A, vol. 18, pp. 1645-1651, 1987.
[22] P. Ghosh, M. Mezbahul-Islam, and M. Medraj, "Critical assessment and thermodynamic modeling of Mg-Zn, Mg-Sn, $\mathrm{Sn}-\mathrm{Zn}$ and Mg-Sn-Zn systems," Calphad, vol. 36, pp. 28-43, 2012.

[23] Magnesuum overview, 2013, http://www.intlmag.org/index .cfm.

[24] H. Pyka, Untersuchungen zur thermodynamik glasbildender ternärer Legierungen [Ph.D. thesis], University Stuttgart, Stuttgart, Germany, 1984.

[25] M. Kawakami, Scientific Reports of Reserch Institute Tohoku University, vol. 19, 1930.

[26] R. Agarwal, S. G. Fries, H. L. Lukas et al., "Assessment of the Mg-Zn system," Zeitschrift für Metallkunde, vol. 83, pp. 216-223, 1992.

[27] A. M. Pogodaev and E. E. Lukashenko, "Thermodynamic study of molten magnesium and zinc alloys," Zhurnal Fizicheskoi Khimii, vol. 46, pp. 337-339, 1972.

[28] Z. Moser, "Thermodynamic properties of dilute solutions of magnesium in zinc," Metallurgical and Materials Transactions, vol. 5, no. 6, pp. 1445-1450, 1974.

[29] P. Chiotti and E. P. Stevens, "Thermodynamic properties of MgZn alloys," Transactions of the American Society for Metals, vol. 233, pp. 198-203, 1965.

[30] J. Terpilowski, "Thermodynamic properties of liquid zincmagnesium solutions," Bulletin de l'Academie Polonaise des Sciences, Serie des Sciences Chimiques, vol. 10, pp. 221-225, 1962.

[31] Z. Kozuka, J. Moriyama, and I. Kushima, "Activities of the component metals in fused binary alloys ( $\mathrm{Zn}-\mathrm{Al}$ system and $\mathrm{Zn}$ Mg system)," Denki Kagaku, vol. 28, pp. 523-526, 1960.

[32] M. Asgar-Khan and M. Medraj, "Thermodynamic description of the Mg-Mn, Al-Mn and Mg-Al-Mn systems using the modified quasichemical model for the liquid phases," Materials Transactions, vol. 50, no. 5, pp. 1113-1122, 2009.

[33] M. V. Chukhov, "On the solubility of Mn in liquid Mg," Doklady Akademii Nauk SSSR, vol. 1, pp. 302-305, 1958.

[34] M. Drits, E. Padezhnova, and N. Miklina, "The combined solubility of noedymium and zinc in solid magnesium," Russian Metallurgy, vol. 3, pp. 143-146, 1974.

[35] A. Schneider and S. Hennistobbe, "Structure and technical preparation of corrosion-resistant magnesium-manganese alloys," Metall, vol. 4, pp. 178-183, 1950.

[36] G. Siebel, "The solubility of iron, manganese, and zirconium in magnesium and magnesium alloys," Zeitschrift für Metallkunde, vol. 39, pp. 22-27, 1948.

[37] N. Tiner, "The solubility of manganese in liquid magnesium," Metals Technology, pp. 1-7, 1945.

[38] J. D. Grogan and J. L. Haughton, "Alloys of Mg. XIV. The constitution of the Mg-rich alloys of $\mathrm{Mg}$ and $\mathrm{Mn}$," Journal of the Institute of Metals, vol. 69, pp. 241-248, 1943.

[39] M. E. Drits, Z. A. Sviderskaya, and L. L. Rokhlin, "Alloys of the system magnesium-neodymium-manganese in the region close to the magnesium corner," Zhurnal Neorganicheskoi Khimii, vol. 7, pp. 2771-2777, 1962.

[40] E. Schmid and G. Siebel, "Determination of solid solubility of Mn in Mg by x-ray analysis," Metallwirtschaft, vol. 10, pp. 923925, 1931.

[41] M. Aljarrah and M. Medraj, "Thermodynamic modelling of the $\mathrm{Mg}-\mathrm{Ca}, \mathrm{Mg}-\mathrm{Sr}$, $\mathrm{Ca}-\mathrm{Sr}$ and $\mathrm{Mg}-\mathrm{Ca}-\mathrm{Sr}$ systems using the modified quasichemical model," Calphad, vol. 32, no. 2, pp. 240-251, 2008. 
[42] P. Ghosh and M. Medraj, "Thermodynamic calculation of the $\mathrm{Mg}-\mathrm{Mn}-\mathrm{Zn}$ and $\mathrm{Mg}$-Mn-Ce systems and re-optimization of their constitutive binaries," Calphad, vol. 41, pp. 89-107, 2013.

[43] F. Islam and M. Medraj, "The phase equilibria in the Mg-Ni-Ca system," Calphad, vol. 29, no. 4, pp. 289-302, 2005.

[44] M. Mezbahul-Islam, E. Essadiqi, and M. Medraj, "A differential scanning calorimetric study of the $\mathrm{Mg}-\mathrm{Cu}-\mathrm{Y}$ system," Materials Science Forum, vol. 706-709, pp. 1215-1220, 2012.

[45] M. Mezbahul-Islam and M. Medraj, "A critical thermodynamic assessment of the Mg-Ni, Ni-Y binary and $\mathrm{Mg}-\mathrm{Ni}-\mathrm{Y}$ ternary systems," Calphad, vol. 33, no. 3, pp. 478-486, 2009.

[46] M. Mezbahul-Islam and M. Medraj, "Thermodynamic modeling of the Mg-Cu-Ni ternary system using the modified quasichemical model," in Proceedings of the Conference of Metallurgists (COM '11), pp. 241-253, Montreal, Canada, 2011.

[47] S. Wasiur-Rahman and M. Medraj, "Critical assessment and thermodynamic modeling of the binary $\mathrm{Mg}-\mathrm{Zn}, \mathrm{Ca}-\mathrm{Zn}$ and ternary Mg-Ca-Zn systems," Intermetallics, vol. 17, no. 10, pp. 847-864, 2009.

[48] M. A. Parvez, M. Medraj, E. Essadiqi, A. Muntasar, and G. Dénès, "Experimental study of the ternary magnesiumaluminium-strontium system," Journal of Alloys and Compounds, vol. 402, no. 1-2, pp. 170-185, 2005.

[49] T. Balakumar and M. Medraj, "Thermodynamic modeling of the Mg-Al-Sb system," Calphad, vol. 29, no. 1, pp. 24-36, 2005.

[50] F. Islam and M. Medraj, "Thermodynamic modelling of the MgAl-Ca system," Canadian Metallurgical Quarterly, vol. 44, no. 4, pp. 523-536, 2005.

[51] F. Islam, A. K. Thykadavil, and M. Medraj, "A computational thermodynamic model of the Mg-Al-Ge system," Journal of Alloys and Compounds, vol. 425, no. 1-2, pp. 129-139, 2006.

[52] S. Al Shakhshir and M. Medraj, "Computational thermodynamic model for the Mg-Al-Y system," Journal of Phase Equilibria and Diffusion, vol. 27, no. 3, pp. 231-244, 2006.

[53] M. Aljarrah, U. Aghaulor, and M. Medraj, "Thermodynamic assessment of the Mg-Zn-Sr system," Intermetallics, vol. 15, no. 2, pp. 93-97, 2007.

[54] M. Aljarrah, M. Medraj, J. Li, and E. Essadiqi, "Phase equilibria of the constituent ternaries of the Mg-Al-Ca-Sr system," JOM, vol. 61, no. 5, pp. 68-74, 2009.

[55] Y.-N. Zhang, D. Kevorkov, J. Li, E. Essadiqi, and M. Medraj, "Determination of the solubility range and crystal structure of the Mg-rich ternary compound in the Ca-Mg-Zn system," Intermetallics, vol. 18, no. 12, pp. 2404-2411, 2010.

[56] Y. N. Zhang, D. Kevorkov, F. Bridier, and M. Medraj, "Experimental study of the Ca-Mg-Zn system using diffusion couples and key alloys," Science and Technology of Advanced Materials, vol. 12 , no. 2 .

[57] M. Mezbahul-Islam and M. Medraj, "Phase equilibrium in MgCu-Y," Scientific Reports, vol. 3, article 3033, 2013.

[58] F. Sommer, B. Predel, and D. Assman, "Thermodynamic investigation of liquid alloys in the systems $\mathrm{Mg}-\mathrm{Ca}, \mathrm{Mg}-\mathrm{Sr}$, and $\mathrm{Mg}-$ Ba," Zeitschrift für Metallkunde, vol. 68, pp. 347-349, 1977.

[59] V. P. Mashovets and L. V. Puchkov, "Vapour pressure over molten alloys in the system Mg-Ca," Zhurnal Prikladnoi Khimii, vol. 35, pp. 1009-1014, 1965.

[60] F. Sommer, "Thermodynamic activities of liquid alloys in the system Ca-Mg using a modified ruff method," Zeitschrift für Metallkund, vol. 70, no. 8, pp. 545-547, 1979.

[61] F. Sommer, "Determination of thermodynamic activities of liquid alloys in the systems $\mathrm{Mg}-\mathrm{Sr}$ and Ba-Mg," Zeitschrift für Metallkunde, vol. 71, pp. 434-437, 1980.
[62] H. D. Zhao, G. W. Qin, Y. P. Ren, W. L. Pei, D. Chen, and Y. Guo, "The maximum solubility of $\mathrm{y}$ in $\alpha$-Mg and composition ranges of $\mathrm{Mg}_{24} \mathrm{Y}_{5-x}$ and $\mathrm{Mg}_{2} \mathrm{Y}_{1-x}$ intermetallic phases in $\mathrm{Mg}$ - $\mathrm{Y}$ binary system," Journal of Alloys and Compounds, vol. 509, no. 3, pp. 627-631, 2011.

[63] H. Flandorfer, M. Giovannini, A. Saccone, P. Rogl, and R. Ferro, "The Ce-Mg-Y system," Metallurgical and Materials Transactions A, vol. 28, no. 2, pp. 265-276, 1997.

[64] Z. A. Sviderskaya and E. M. Padezhnova, "Phase equilibriums in magnesium-yttrium and magnesium-yttrium-manganese systems," Izvestiya Akademii Nauk SSSR, Metally, pp. 183-190, 1968.

[65] J. F. Smith, D. M. Bailey, D. B. Novotny, and J. E. Davison, “Thermodynamics of formation of yttrium-magnesium intermediate phases," Acta Metallurgica, vol. 13, no. 8, pp. 889-895, 1965.

[66] M. Mezbahul-Islam, D. Kevorkov, and M. Medraj, "The equilibrium phase diagram of the magnesium-copper-yttrium system," The Journal of Chemical Thermodynamics, vol. 40, no. 7, pp. 1064-1076, 2008.

[67] R. Agarwal, H. Feufel, and F. Sommer, "Calorimetric measurements of liquid LaMg, MgYb and MgY alloys," Journal of Alloys and Compounds, vol. 217, no. 1, pp. 59-64, 1995.

[68] V. Ganesan, F. Schuller, H. Feufel, F. Sommer, and H. Ipser, "Thermodynamic properties of ternary liquid $\mathrm{Cu}-\mathrm{Mg}-\mathrm{Y}$ alloys," Zeitschrift für Metallkunde, vol. 88, no. 9, pp. 701-710, 1997.

[69] V. Ganesan and H. Ipser, "Thermodynamic properties of liquid magnesium-yttrium alloys," Journal de Chimie Physique et de Physico-Chimie Biologique, vol. 94, no. 5, pp. 986-991, 1997.

[70] I. N. Pyagai, A. V. Vakhobov, N. G. Shmidt, O. V. Zhikhareva, and M. I. Numanov, "Heats of formation of magnesium intermetallic compounds with yttrium, lanthanum, and neodymium," Doklady Akademii Nauk Tadzhikshoi SSR, vol. 32, pp. 605-607, 1989.

[71] H. Zhang, S. Shang, J. E. Saal et al., "Enthalpies of formation of magnesium compounds from first-principles calculations," Intermetallics, vol. 17, no. 11, pp. 878-885, 2009.

[72] I. T. Sryvalin, O. A. Esin, and B. M. Lepinskikh, “Thermodynamic properties of solutions of magnesium in nickel, lead, and silicon," Zhurnal Fizicheskoi Khimii, vol. 38, pp. 637-641, 1964.

[73] K. Micke and H. Ipser, "Thermodynamic properties of liquid magnesium-nickel alloys," Monatshefte fur Chemie, vol. 127, no. 1, pp. 7-13, 1996.

[74] P. Sieben and N. G. Schmahl, "Vapor pressure and activity of magnesium in the binary alloy systems with nickel and copper and vapor pressures of some pure metals," Giesserei, TechnischWissenschaftliche Beihefte, Giessereiwesen und Metallkunde, vol. 18, pp. 197-211, 1966.

[75] P. Schubel, "The heat capacity of metals and metallic compounds between 18 and $600^{\circ}$, , Zeitschrift Fuer Anorganische Chemie, vol. 87, pp. 81-119, 1914.

[76] J. F. Smith and J. L. Christian, "Thermodynamics of formation of coppermagnesium and nickelmagnesium compounds from vapor pressure measurements," Acta Metallurgica, vol. 8, no. 4, pp. 249-255, 1960.

[77] R. C. King and O. J. Kleppa, "A thermochemical study of some selected laves phases," Acta Metallurgica, vol. 12, no. 1, pp. 87-97, 1964.

[78] G. M. Lukashenko and V. N. Eremenko, "Thermodynamic properties of alloys in the system magnesium-nickel in the solid state," Zvestiya Akademii Nauk SSSR, Metally, pp. 161-164, 1966.

[79] A. D. Pelton, S. A. Degterov, G. Eriksson, C. Robelin, and Y. Dessureault, "The modified quasichemical model I-binary 
solutions," Metallurgical and Materials Transactions B, vol. 31, no. 4, pp. 651-659, 2000.

[80] M. Hillert, "The compound energy formalism," Journal of Alloys and Compounds, vol. 320, no. 2, pp. 161-176, 2001.

[81] M. Kawakami, "Equilibrium diagram of aluminum-magnesium system," Science Reports of the Tohoku Imperial University series 1, pp. 727-747, 1936.

[82] G. Siebel and H. Vosskuhler, "The determination of the solubility of magnesium in aluminum," Zeitschrift für Metallkunde, vol. 31, pp. 359-362, 1939.

[83] N. S. Kurnakov and V. I. Mikheeva, "Transformations in the middle part of the system aluminum-magnesium," Doklady Akademii Nauk SSSR, vol. 13, pp. 209-224, 1940.

[84] N. S. Kurnakov and V. I. Mikheeva, "Properties of solid solutions of magnesium and aluminum in the system aluminummagnesium," Doklady Akademii Nauk SSSR, vol. 13, pp. 201-208, 1940.

[85] E. Butchers and W. Hume-Rothery, "Constitution of aluminummagnesium-manganese-zinc alloys: the solidus," Journal of the Institute of Metals, vol. 71, pp. 291-311, 1945.

[86] W. Stiller and H. Hoffineister, "Determination of liquidsolid phase equilibria of aluminum-magnesium-zinc alloy," Zeitschrift für Metallkdune, vol. 70, pp. 167-172, 1979.

[87] E. Schuermann and H. J. Voss, "Melting equilibriums of magnesium-lithium-aluminum alloys. Part 4. Melting equilibriums of the aluminum-magnesium binary system," Giessereiforschung, vol. 33, pp. 43-46, 1981.

[88] N. C. Goel, J. R. Cahoon, and B. Mikkelsen, "An experimental technique for the rapid determination of binary phase diagrams: the Al-Mg system," Metallurgical Transactions A, vol. 20, no. 2, pp. 197-203, 1989.

[89] E. Schuermann and A. Fischer, "Melting equilibria in the ternary aluminum magnesium silicon system-1. Binary aluminum magnesium alloys," Giessereiforschung, vol. 29, no. 3, pp. 107-111, 1977.

[90] E. Schuermann and I. K. Geissler, "Phase equilibriums in the solid condition of the aluminum- rsp. the magnesium-rich corner of the ternary system of aluminum-lithium-magnesium. Part 3. Phase equilibriums in the solid condition of the binary system of aluminium-magnesium," Giessereiforschung, vol. 32, pp. 167-170, 1980.

[91] P. Liang, H. L. Su, P. Donnadieu, M. Harmelin, and A. Quivy, "Experimental investigation and thermodynamic calculation of the central part of the Mg-AI phase diagram," Zeitschrift für Metallkunde, vol. 89, pp. 536-540, 1998.

[92] D. Hanson and M. L. Gayler, "The constitution of the alloys of aluminum and magnesium," Journal of Institute of Metals, vol. 24, pp. 201-232, 1920.

[93] W. Hume-Rothery and G. V. Raynor, "The constitution of the mgnesium-rich alloys in the systems aluminummagnesium, gallium-magnesium, indium-magnesium, and hallium-magnesium," Journal of the Institute of Metals, vol. 63, pp. 201-226, 1938.

[94] E. S. Makarkov, "Crystal structure of the gamma phase of the systems Al-Mg and Tl-Bi," Doklady Akademii Nauk SSSR, vol. 74, pp. 935-938, 1950.

[95] J. L. Murray, “The Al-Mg (Aluminum-Magnesium) system," Bulletin of Alloy Phase Diagrams, vol. 3, no. 1, pp. 60-74, 1982.

[96] P. Chartrand and A. D. Pelton, "Critical evaluation and optimization of the thermodynamic properties and phase diagrams of the Al-Mg, Al-Sr, Mg-Sr, and Al-Mg-Sr systems," Journal of Phase Equilibria, vol. 15, no. 6, pp. 591-605, 1994.
[97] N. Saunders, "A review and thermodynamic assessment of the aluminum-magnesium and magnesium-lithium systems," Calphad, vol. 14, pp. 61-70, 1990.

[98] T. Czeppe, W. Zakulski, and E. Bielańska, "Study of the thermal stability of phases in the Mg-Al system," Journal of Phase Equilibria, vol. 24, no. 3, pp. 249-254, 2003.

[99] Y. Zuo and Y. A. Chang, "Thermodynamic calculation of the AlMg phase diagram," Calphad, vol. 17, no. 2, pp. 161-174, 1993.

[100] K. Ozturk, Z.-K. Liu, and A. A. Luo, "Phase identification and microanalysis in the Mg-Al-Ca alloy system," in Proceedings of the Magnesium Technology, pp. 195-200, March 2003.

[101] Y. Zhong, M. Yang, and Z.-K. Liu, "Contribution of firstprinciples energetics to Al-Mg thermodynamic modeling," Calphad, vol. 29, no. 4, pp. 303-311, 2005.

[102] G. I. Batalin, V. E. Sokol'skii, and T. B. Shimanskaya, "Enthalpies of mixing liquid alloys of aluminum with magnesium and antimony," Ukrainskii Khimicheskii Zhurnal, vol. 37, p. 397, 1971.

[103] N. M. Tsyplakova and K. L. Strelets, “Thermodynamic properties of a magnesium-aluminum system studied by an emf method," Zhurnal Prikladnoi Khimii, vol. 42, no. 11, pp. 24982503, 1969.

[104] M. Aljarrah, Thermodynamic modeling and experimental investigation of the $\mathrm{Mg}$-Al-Ca-Sr system [Ph.D. thesis], Mechanical and Industrial Engineering, Concordia University, Montreal, Canada, 2008.

[105] O. Boudouard, "Alloys of zinc and magnesium," Proceedings of the National Academy of Sciences, vol. 139, pp. 424-426, 1904.

[106] G. Grube, "Alloys of magnesium with cadmium, zinc, bismuth and antimony," The Journal of Physical Chemistry, vol. 10, pp. 587-592, 1906.

[107] R. J. Chadwick, "The constitution of the alloys of magnesium and zinc," Journal of the Institute of Metals, vol. 449, pp. 285299, 1928.

[108] S. Samson, "The crystal structure of $\mathrm{Mg}_{2} \mathrm{Zn}_{11}$ : isomorphism between $\mathrm{Mg}_{2} \mathrm{Zn}_{11}$ and $\mathrm{Mg}_{2} \mathrm{Cu}_{6} \mathrm{Al}_{5}$," Acta Chemica Scandinavica, vol. 3, pp. 835-843, 1949.

[109] J. J. Park and L. L. Wyman, "Phase relationships in magnesium alloys," WADC Technical Report: Astia Document AD142110 57-504, 1957.

[110] E. D. R. W. Hume-Rothery, "The system magnesium-zinc," Journal of the Institute of Metals, vol. 41, pp. 119-138, 1929.

[111] F. Laves, "Zur konstitution der magnesium-zink-legierungen," Die Naturwissenschaften, vol. 27, no. 26, pp. 454-455, 1939.

[112] J. Clark and F. Rhins, "Central region of the Mg-Zn phase diagram," Journal of Metals, vol. 9, pp. 425-430, 1957.

[113] I. Higashi, N. Shiotani, M. Uda, T. Mizoguchi, and H. Katoh, "The crystal structure of $\mathrm{Mg}_{51} \mathrm{Zn}_{20}$ " Journal of Solid State Chemistry, vol. 36, no. 2, pp. 225-233, 1981.

[114] J. B. Clark, L. Zabdyr, and Z. Moser, Phase Diagrams of Binary Magneisium Alloys, ASM INTERNATIONAL, Metals Park, Ohio, USA, 1988.

[115] P. Liang, T. Tarfa, J. A. Robinson et al., "Experimental investigation and thermodynamic calculation of the Al-Mg-Zn system," Thermochimica Acta, vol. 314, no. 1-2, pp. 87-110, 1998.

[116] C. W. Bale, P. Chartrand, S. A. Degterov et al., FTlight Thermochemical Database, CRCT, Montreal, Canada, 2013.

[117] F. Sommer, J. J. Lee, and B. Predel, "Calorimetric investigations of liquid alkaline earth metal alloys," Berichte der Bunsengesellschaft für Physikalische Chemie, vol. 87, pp. 792-797, 1983. 
[118] A. V. Volkovich, A. V. Krivopushkin, and I. F. Nichkov, "Thermodynamic properties of zinc-strontium alloys," Izv Vyssh Uchebn Zaved Tsvetn Metall, pp. 29-31, 1987.

[119] J. M. Juneja, G. N. K. Iyengar, and K. P. Abraham, “Thermodynamic properties of liquid (magnesium + copper) alloys by vapour-pressure measurements made by a boiling-temperature method," The Journal of Chemical Thermodynamics, vol. 18, no. 11, pp. 1025-1035, 1986.

[120] S. P. Garg, Y. J. Bhatt, and C. V. Sundaram, "Thermodynamic study of liquid $\mathrm{Cu}-\mathrm{Mg}$ alloys by vapor pressure measurements," Metallurgical Transactions, vol. 4, no. 1, pp. 283-289, 1973.

[121] N. G. Schmahl and P. Sieben, "Vapor pressures of magnesium in its binary alloys with copper, nickel, and lead and their thermodynamic evaluation," Physical Chemistry of Metallic Solutions and Intermetallic Compounds, Symposium, vol. 1, pp. 268-282, 1960.

[122] M. Hino, T. Nagasaka, and R. Takehama, "Activity measurement of the constituents in liquid $\mathrm{Cu}-\mathrm{Mg}$ and $\mathrm{Cu}-\mathrm{Ca}$ alloys with mass spectrometry," Metallurgical and Materials Transactions B, vol. 31, pp. 927-935, 2000.

[123] V. N. Eremenko, G. M. Lukashenko, and R. I. Polotskaya, "Thermodynamic properties of magnesium-copper compounds," Izvestiya Akademii Nauk SSSR, Metally, pp. 210-212, 1968.

[124] V. N. Eremenko and G. M. Lukashenko, "Thermodynamic properties of $\mathrm{Mg}-\mathrm{Pb}$ system," Ukrainskii Khimicheskii Zhurnal, vol. 29, pp. 896-900, 1963.

[125] A. Steiner, E. Miller, and K. L. Komarek, "Magnesium-tin phase diagram and thermodynamic properties of liquid magnesiumtin alloys," Transactions of Metals Society AIME, vol. 230, pp. 1361-1367, 1964.

[126] J. M. Eldridge, E. Miller, and K. L. Komarek, Transactions of the Metals Society AIME, vol. 239, pp. 775-781, 1967.

[127] R. A. Sharma, "Thermodynamic properties of liquid $\mathrm{Mg}+\mathrm{Pb}$ and $\mathrm{Mg}+\mathrm{Sn}$ Alloys by e.m.f. measurements," The Journal of Chemical Thermodynamics, vol. 2, no. 3, pp. 373-389, 1970.

[128] A. K. Nayak and W. Oelsen, "Determination of the heats of formation of the solid and liquid $\mathrm{Mg}$ - Sn alloys at $20^{\circ}$ and $800^{\circ} \mathrm{C}$ respectively and the heat content of the alloys at $800^{\circ} \mathrm{C}$," Transactions of the Indian Institute of Metals, vol. 24, no. 2, pp. 66-73, 1971.

[129] M. Morishita, K. Koyama, S. Shikata, and M. Kusumoto, "Standard gibbs energy of formation of Mg48Zh52 determined by solution calorimetry and measurement of heat Capacity from near absolute zero kelvin," Metallurgical and Materials Transactions B, vol. 35, no. 5, pp. 891-895, 2004.

[130] M. Morishita, H. Yamamoto, S. Shikada, M. Kusumoto, and Y. Matsumoto, "Thermodynamics of the formation of magnesium-zinc intermetallic compounds in the temperature range from absolute zero to high temperature," Acta Materialia, vol. 54, no. 11, pp. 3151-3159, 2006.

[131] M. Morishita, K. Koyama, S. Shikada, and M. Kusumoto, "Calorimetric study of Mg2Zn3," Zeitschrift für Metallkunde, vol. 96, no. 1, pp. 32-37, 2005.

[132] M. Morishita and K. Koyama, "Calorimetric study of MgZn2 and Mg2Zn11," Zeitschrift für Metallkunde, vol. 94, no. 9, pp. 967-971, 2003.

[133] D. A. Petrov, M. S. Mirgalovskaya, I. A. Strelnikova, and E. M. Komova, The Constitution Diagram For the MagnesiumManganese System, vol. 1, Institute of Materials Science, Academy of Sciences of the Ukrainian SSR, 1958.
[134] A. A. Nayeb-Hashemi and J. B. Clark, "The Mg-Mn (Magnesium-Manganese) system," Bulletin of Alloy Phase Diagrams, vol. 6, no. 2, pp. 160-164, 1985.

[135] J. Gröbner, D. Mirkovic, M. Ohno, and R. Schmid-Fetzer, "Experimental investigation and thermodynamic calculation of binary Mg-Mn Phase equilibria," Journal of Phase Equilibria and Diffusion, vol. 26, no. 3, pp. 234-239, 2005.

[136] Y.-B. Kang, A. D. Pelton, P. Chartrand, P. Spencer, and C. D. Fuerst, "Thermodynamic database development of the Mg-CeMn-Y system for Mg alloy design," Metallurgical and Materials Transactions A, vol. 38, no. 6, pp. 1231-1243, 2007.

[137] P. Villars and K. Cenzual, Pearaon'a Cryatal Data-Cryatal Structure Database for Inorganic Compounda (on CD-ROM), ASM International, Materials Park, Ohio, USA, 2009.

[138] J. A. Brown and J. N. Pratt, "The thermodynamic properties of solid Al-Mg alloys," Metallurgical Transactions, vol. 1, no. 10, pp. 2743-2750, 1970.

[139] B. Predel and K. Huelse, "Thermodynamic properties of aluminum-magnesium alloys," Zeitschrift für Metallkunde, vol. 69, no. 10, pp. 661-666, 1978.

[140] H. Okamoto, "Supplemental literature review of binary phase diagrams: Cs-In, Cs-K, Cs-Rb, Eu-In, Ho-Mn, K-Rb, Li-Mg, Mg-Nd, Mg-Zn, Mn-Sm, O-Sb, and Si-Sr," Journal of Phase Equilibria and Diffusion, vol. 34, pp. 251-263, 2013.

[141] P. Villars and L. Calvert, “K. Pearson's Crystal Data, Crystal Structure Database for Inorganic Compounds, CD-ROM software version 1. 3," OH, 2009.

[142] A. Schneider, H. Klotz, J. Stendel, and G. Strauss, "Thermochemistry of alloys," Pure and Applied Chemistry, vol. 2, pp. 1316, 1961.

[143] A. Berche, C. Drescher, J. Rogez, M.-C. Record, S. Brühne, and W. Assmus, "Thermodynamic measurements in the MgZn system," Journal of Alloys and Compounds, vol. 503, no. 1, pp. 44-49, 2010.

[144] W. Biltz and G. Hohorst, "Contributions to the systematic study of affinity. XV. The heats of formation of the compounds of metallic magnesium with metallic zinc, cadmium, aluminium and calcium," Zeitschrift für Anorganische und Allgemeine Chemie, vol. 121, pp. 1-24, 1922.

[145] N. Baar, "On the alloys of molybdenum with nickel, manganese with thallium, and calcium with magneisum, thallium, lead, copper, and silver," Zeitschrift für Anorganische und Allgemeine Chemie, vol. 70, pp. 362-366, 1911.

[146] M. W. Chase, "Heat of transition of the elements," Bulletin of Alloy Phase Diagrams, vol. 4, pp. 123-124, 1983.

[147] R. Paris, “Contribution on the ternary alloys," Ministère de L'Air: Publications Scientifiques et Techniques du Ministére de L'Air, vol. 45, pp. 39-41, 1934.

[148] J. L. Haughton, "Alloys of magnesium. Part 6-the construction of the magnesium-rich alloys of magnesium and calcium," Journal of Institute of Metals, vol. 61, pp. 241-246, 1937.

[149] H. Vosskühler, "The Phase diagram of magnesium-rich Mg-Ca alloys," Zeitschrift für Metallkunde, vol. 29, pp. 236-237, 1937.

[150] W. Klemm and F. Dinkelacker, "On the behavior of magnesium with calcium, strontium, and barium," Zeitschrift für Anorganische und Allgemeine Chemie, vol. 255, pp. 2-12, 1947.

[151] J. F. Smith and R. L. Smythe, "Vapor pressure measurements over calcium, magnesium and their alloys and the thermodynamics of formation of CaMg2," Acta Metallurgica, vol. 7, no. 4, pp. 261-267, 1959. 
[152] P. Chiotti, R. W. Curtis, and P. F. Woerner, "Metal hydride reactions. II. Reaction of hydrogen with CaMG2 and CaCU5 and thermodynamic properties of the compounds," Journal of The Less-Common Metals, vol. 7, no. 2, pp. 120-126, 1964.

[153] J. E. Davison and J. F. Smith, "Enthalpy of formation of CaMg2," Transactions of the Metallurgical Society of AIME, vol. 242, pp. 2045-2049, 1968.

[154] G. J. Gartner, Application of an Adiabatic Calorimeter to the Determination of the Heats of Fusion And Heats of Formation of Several Metallic Compounds, Iowa State University, Ames, Iowa, USA, 1965.

[155] I. N. Pyagai and A. V. Vakhobov, "Heats of formation of intermetallic compounds in the systems magnesium-calcium (strontium, barium)," Zhurnal Fizicheskoi Khimii, vol. 64, pp. 2788-2789, 1990.

[156] Y. Zhong, K. Ozturk, J. O. Sofo, and Z.-K. Liu, "Contribution of first-principles energetics to the $\mathrm{Ca}-\mathrm{Mg}$ thermodynamic modeling," Journal of Alloys and Compounds, vol. 420, no. 1-2, pp. 98-106, 2006.

[157] Z. Yang, J. Du, C. Hu, R. Melnik et al., "First principles studies on the structural, elastic, electronic properties and heats of formation of $\mathrm{Mg}-\mathrm{AE}(\mathrm{AE}=\mathrm{Ca}, \mathrm{Sr}, \mathrm{Ba})$ intermetallics," Intermetallics, vol. 32, pp. 156-161, 2013.

[158] Y. Zhong, J. O. Sofo, A. A. Luo, and Z. Liu, “Thermodynamics modeling of the Mg-Sr and Ca-Mg-Sr systems," Journal of Alloys and Compounds, vol. 421, pp. 172-178, 2006.

[159] H. Nowotny, E. Wormnes, and E. Mohrnheim, "Investigation on the $\mathrm{Al}-\mathrm{Ca}, \mathrm{Mg}-\mathrm{Ca}$, and $\mathrm{Mg}-\mathrm{Zr}$ systems," Zeitschrift für Metallkunde, vol. 32, pp. 39-42, 1940.

[160] E. C. Burke, "Solid solubility of calcium in magnesium," Journal of Metals Transactions of AIME, vol. 203, pp. 285-286, 1955.

[161] E. F. W. Bulian, "Solubility of calcium in magnesium," Metallforschung, vol. 1, p. 70, 1946.

[162] X. Tao, Y. Ouyang, H. Liu et al., "Phase stability of magnesiumrare earth binary systems from first-principles calculations," Journal of Alloys and Compounds, vol. 509, no. 24, pp. 68996907, 2011.

[163] K. H. J. Buschow, "Magnetic properties of $\mathrm{MgCo}_{2}, \mathrm{MgNi}_{2}$ and $\mathrm{Mg}_{2} \mathrm{Ni}$," Solid State Communications, vol. 17, no. 7, pp. 891-893, 1975.

[164] F. Laves and H. Witte, "X-ray determination of structure of MgNi2," Metallwirtschaft, Metallwissenschaft, Metalltechnik, vol. 14, p. 1002, 1935.

[165] H. Okamoto, "Ce-Mg (Cerium-Magnesium)," Journal of Phase Equilibria and Diffusion, vol. 32, pp. 265-266, 2011.

[166] R. Agarwal, J. J. Lee, H. L. Lukas, and F. Sommer, "Calorimetric measurements and thermodynamic optimization of the Ca-Mg system," Zeitschrift für Metallkunde, vol. 86, no. 2, pp. 103-108, 1995.

[167] B. P. Burylev, "Thermodynamic properties of calcium based alloys," in Termodin Termokhin Konstanty Izd. Nauka, K. V. Astakhov, Ed., pp. 32-39, USSR, Moscow, Russia, 1970.

[168] W. Biltz and H. Pieper, "Contributions to the systematic affinity principle. XXVII. The heats of formation of intermetallic compounds. IV. Cerium alloys," Zeitschrift Für Anorganische und Allgemeine Chemie., vol. 134, pp. 13-24, 1924.

[169] J. Pahlman and J. Smith, "Thermodynamics of formation of compounds in the Ce-Mg, Nd-Mg, Gd-Mg, Dy-Mg, Er-Mg, and $\mathrm{Lu}-\mathrm{Mg}$ binary systems in the temperature range 650to 930K," Metallurgical and Materials Transactions B, vol. 3, pp. 2423-2432, 1972.
[170] K. Nagarajan and F. Sommer, "Calorimetric investigations of CeMg liquid alloys," Journal of The Less-Common Metals, vol. 142, pp. 319-328, 1988.

[171] Y. B. Kang, L. Jin, P. Chartrand, A. E. Gheribi, K. Bai, and P. Wu, "Thermodynamic evaluations and optimizations of binary Mglight Rare Earth (La, Ce, Pr, Nd, Sm) systems," Calphad, vol. 38, pp. 100-116, 2012.

[172] F. Sommer, J. J. Lee, and B. Predel, “Temperaturabhängigkeit der mischungsenthalpien flüssiger Magnesium-Blei und Magnesium-Zinn Legierungen," MetaUkd, vol. 71, pp. 818-821, 1980.

[173] A. K. Nayak and W. Oelsen, "Determination of the heats of formation of the solid and liquid $\mathrm{Mg}$ - Sn alloys at $20^{\circ}$ and $800^{\circ} \mathrm{C}$ respectively and the heat content of the alloys at $800^{\circ} \mathrm{C}$," Transactions of the Indian Institute of Metals, vol. 24, no. 2, pp. 66-73, 1971.

[174] P. Beardmore, B. W. Howlett, Lichter, B. D et al., "Thermodynamic properties of compounds of magnesium and group IVB elements," Transactions of Metals Society AIME, vol. 236, pp. 102-108, 1966.

[175] A. Borsese, G. Borzone, R. Ferro, and R. Capelli, "Heat of formation of magnesium-tin alloys," Zeitschrift für Metallkunde, vol. 66, no. 4, pp. 226-227, 1975.

[176] B. Dobovisek and A. Paulin, "Influence of the structure of intermetallic compounds on thermodynamic properties of metallic systems," Rudarsko Metals of Zbornik, vol. 1, pp. 37-49, 1966.

[177] A. A. Nayeb-Hashemi and J. B. Clark, "The Ca-Mg (calciummagnesium) system," Bulletin of Alloy Phase Diagrams, vol. 8, no. 1, pp. 58-65, 1987.

[178] A. A. Nayeb-Hashemi and J. B. Clark, "The Mg-Sr (MagnesiumStrontium) system," Bulletin of Alloy Phase Diagrams, vol. 7, no. 2, pp. 149-156, 1986.

[179] H. Vosskuehler, "The structure of the magnesium-rich alloys of magnesium and strontium," Metallwirtschaft, vol. 18, pp. 377378, 1939.

[180] J. W. Brown, The strontium-magnesium phase system [Ph.D. thesis], Syracuse University, Syracuse, NY, USA, 1973.

[181] J. P. Ray, The strontium-magnesium equilibrium diagram [Ph.D. thesis], Syracuse University, Syracuse, NY, USA, 1947.

[182] H. Vosskuhler, "The structure of the magnesium-rich magnesium-strontium alloys," Metallwirtsch, Metallwiss, Metalltech, vol. 18, pp. 377-378, 1939.

[183] E. D. Gibson and O. N. Carlson, "The yttrium-magnesium alloy system," Transactions of the American Society For Metals, vol. 52, pp. 1084-1096, 1960.

[184] D. Mizer and J. B. Clark, "Magnesium-rich region of the magnesium-yttrium phase diagram," Transactions of the American Institute of Mining, Metallurgical and Petroleum Engineers, vol. 221, pp. 207-208, 1961.

[185] Q. Ran, H. L. Lukas, G. Effenberg, and G. Petzow, "Thermodynamic optimization of the Mg-Y system," Calphad, vol. 12, no. 4, pp. 375-381, 1988.

[186] O. B. Fabrichnaya, H. L. Lukas, G. Effenberg, and F. Aldinger, "Thermodynamic optimization in the Mg-Y system," Intermetallics, vol. 11, no. 11-12, pp. 1183-1188, 2003.

[187] F. G. Meng, J. Wang, H. S. Liu, L. B. Liu, and Z. P. Jin, "Experimental investigation and thermodynamic calculation of phase relations in the Mg-Nd-Y ternary system," Materials Science and Engineering A, vol. 454-455, pp. 266-273, 2007. 
[188] C. Guo, Z. Du, and C. Li, "A thermodynamic description of the Gd-Mg-Y system,” Calphad, vol. 31, no. 1, pp. 75-88, 2007.

[189] Y.-B. Kang, A. D. Pelton, P. Chartrand, P. Spencer, and C. D. Fuerst, "Critical evaluation and thermodynamic optimization of the binary systems in the Mg-Ce-Mn-Y system," Journal of Phase Equilibria and Diffusion, vol. 28, no. 4, pp. 342-354, 2007.

[190] H. Okamoto, "Mg-Y (magnesium-yttrium)," Journal of Phase Equilibria and Diffusion, vol. 31, no. 2, p. 199, 2010.

[191] G. Voss, "Alloys of nickel with tin, lead, thallium, bismuth, chromium, magnesium, zinc, and cadmium," Zeitschrift für Anorganische Chemie, vol. 57, pp. 34-71, 1908.

[192] J. L. Haughton and R. J. M. Payne, "Alloys of magnesium research. I. The constitution of the magnesium-rich alloys of magnesium and nickel," Journal of the Institute of Metals, vol. 54, pp. 275-284, 1934.

[193] P. Bagnoud and P. Feschotte, "Binary systems of magnesiumcopper and magnesium-nickel, especially the nonstoichiometry of the $\mathrm{MgCu}_{2}$ and $\mathrm{MgNi}_{2}$ laves phases," Zeitschrift für Metallkunde, vol. 69, no. 2, pp. 114-120, 1978.

[194] P. D. Merica and R. G. Waltenberg, "Malleability and metallography of nickel," Tech. Paper National Bureau of Standards (U.S) 19, 1925 .

[195] J. S. Wollam and W. E. Wallace, "Magnetic susceptibility, heat capacity and third-law entropy of $\mathrm{MgNi}_{2}$," Journal of Physics and Chemistry of Solids, vol. 13, no. 3-4, pp. 212-220, 1960.

[196] K. H. Lieser and H. Witte, "The ternary systems Mg-Cu-Zn, Mg-Ni-Zn, Mg-Cu-Ni,” Zeitschrift für Metallkunde, vol. 43, pp. 396-401, 1952.

[197] K. Schubert and K. Anderko, "Crystal structure of $\mathrm{NiMg}_{2}$, $\mathrm{CuMg}_{2}$ and $\mathrm{AuMg}_{3}$," Zeitschrift für Metallkunde, vol. 42, pp. 321-324, 1951.

[198] A. A. Nayeb-Hashemi and J. B. Clark, "The Mg-Ni (MagnesiumNickel) system," Bulletin of Alloy Phase Diagrams, vol. 6, no. 3, pp. 238-244, 1985.

[199] M. H. G. Jacobs and P. J. Spencer, "A critical thermodynamic evaluation of the system MG-NI," Calphad, vol. 22, no. 4, pp. 513-525, 1998.

[200] W. Xiong, Y. Du, W.-W. Zhang, W.-H. Sun, X.-G. Lu, and F.-S. Pan, "Thermodynamic reassessment of the Cu-Mg-Ni system with brief comments on the thermodynamic modeling of the sub-systems," Calphad, vol. 32, no. 4, pp. 675-685, 2008.

[201] D. H. Wood and E. M. Cramer, "Phase relations in the magnesium-rich portion of the cerium-magnesium system," Journal of The Less-Common Metals, vol. 9, no. 5, pp. 321-337, 1965.

[202] Q. Johnson and G. Smith, "The crystal structure of $\mathrm{Ce}_{5} \mathrm{Mg}_{42}$," Acta Crystallographica, vol. 22, pp. 360-365, 1967.

[203] A. A. Nayeb-Hashemi and J. B. Clark, "The Ce-Mg (CeriumMagnesium) system," Journal of Phase Equilibria, vol. 9, no. 2, pp. 162-172, 1988.

[204] A. Saccone, D. Macciò, S. Delfino, F. H. Hayes, and R. Ferro, "Mg-Ce alloys. Experimental investigation by smith thermal analysis," Journal of Thermal Analysis and Calorimetry, vol. 66, no. 1, pp. 47-57, 2001.

[205] X. Zhang, D. Kevorkov, and M. Pekguleryuz, "Stoichiometry study on the binary compounds in the Mg-Ce system-Part I," Journal of Alloys and Compounds, vol. 475, no. 1-2, pp. 361-367, 2009.

[206] H. Okamoto and T. B. Massalski, "Thermodynamically improbable phase diagrams," Journal of Phase Equilibria, vol. 12, no. 2, pp. 148-168, 1991.
[207] G. Cacciamani, G. Borzone, and R. Ferro, "System Ce-Mg," in COST 507-Thermochemical Databases for Light Metal Alloys, I. Ansara, A. T. Dinsdale, and M. H. Rand, Eds., vol. 2, pp. 137-140, European Commission, 1998.

[208] H. Zhang, Y. Wang, S. Shang, L.-Q. Chen, and Z.-K. Liu, "Thermodynamic modeling of Mg-Ca-Ce system by combining first-principles and CALPHAD method," Journal of Alloys and Compounds, vol. 463, no. 1-2, pp. 294-301, 2008.

[209] R. Joseph and K. A. Gschneidner, "Solid solubility of magnesium in some lanthanide metals," Transactions of AIME, vol. 233, pp. 2063-2069, 1965.

[210] A. Iandelli and A. Palenzona, "Atomic size of rare earths in intermetallic compounds. MX compounds of $\mathrm{CsCl}$ type," Journal of the Less-Common Metals, vol. 9, no. 1, pp. 1-6, 1965.

[211] S. Delfino, A. Saccone, and R. Ferro, "Phase relationships in the neodymium-magnesium alloy system," Metallurgical Transactions A, vol. 21, no. 8, pp. 2109-2114, 1990.

[212] A. A. Nayeb-Hashemi and J. B. Clark, “The Mg-Nd system (Magnesium-Neodymium)," Bulletin of Alloy Phase Diagrams, vol. 9, no. 5, pp. 618-623, 1988.

[213] S. Gorsse, C. R. Hutchinson, B. Chevalier, and J.-F. Nie, "A thermodynamic assessment of the Mg-Nd binary system using random solution and associate models for the liquid phase," Journal of Alloys and Compounds, vol. 392, no. 1-2, pp. 253-262, 2005.

[214] J. R. Ogren, N. J. Magnani, and J. F. Smith, "Thermodynamics of formation of binary rare earth-magnesium phases with cesium chloride-type structures," Transactions of the Metallurgical Society of AIME, vol. 239, pp. 766-771, 1967.

[215] C. Guo and Z. Du, "Thermodynamic assessment of the Mg-Nd system," Zeitschrift für Metallkunde, vol. 97, pp. 130-135, 2006.

[216] F.-G. Meng, H.-S. Liu, L.-B. Liu, and Z.-P. Jin, “Thermodynamic optimization of Mg-Nd system," Transactions of Nonferrous Metals Society of China (English Edition), vol. 17, no. 1, pp. 7781, 2007.

[217] H. Y. Qi, G. X. Huang, H. Bo, G. L. Xu, L. B. Liu, and Z. P. Jin, "Thermodynamic description of the Mg-Nd-Zn ternary system," Journal of Alloys and Compounds, vol. 509, no. 7, pp. 3274-3281, 2011.

[218] M. O. Boudouard, "Les Alliages de Duirre et de Magnesium (The Binary Alloys of Magnesium)," Bulletin de la Société d'Encouragement pour l'Industrie Nationale, vol. 102, p. 200, 1903.

[219] R. Sahmen, "Alloys of copper with cobalt, iron, manganese and magnesium," Zeitschrift für Anorganische und Allgemeine Chemie, vol. 57, pp. 1-33, 1908.

[220] G. G. Urazov, “Alloys of copper and magnesium," Zhurnal Russkogo Fiziko-Khimicheskogo Obschestva, vol. 39, pp. 15561581, 1907.

[221] W. R. D. Jones, "Copper-magnesium alloys. IV. Equilibrium diagram," Journal of the Institute of Metals, no. 574, p. 25, 1931.

[222] G. Grime and W. Morris-Jones, "An x-ray investigation of the copper-magnesium alloys," Philosophical Magazine Series, vol. 7, pp. 1113-1134, 1929.

[223] V. G. Sederman, "Cu2Mg phase in the copper-magnesium system," Philosophical Magazine Series, vol. 18, pp. 343-352, 1934.

[224] M. Hansen, "Note on the magnesium-rich magnesium copper alloys," Journal of the Institute of Metals, no. 428, p. 8, 1927.

[225] N. I. Stepanov and I. I. Kornilov, "Solubility of copper in magnesium in the solid state," Akademii Nauk SSSR, vol. 7, pp. 89-98, 1935. 
[226] A. A. Nayeb-Hashemi and J. B. Clark, "The Cu-Mg (CopperMagnesium) system," Bulletin of Alloy Phase Diagrams, vol. 5, no. 1, pp. 36-43, 1984.

[227] C. A. Coughanowr, I. Ansara, R. Luoma, M. Hamalainen, and H. L. Lukas, "Assessment of the copper-magnesium system," Zeitschrift für Metallkunde, vol. 82, pp. 574-581, 1991.

[228] Y. Zuo and Y. A. Chang, "Thermodynamic calculation of magnesium-copper phase diagram," Zeitschrift für Metallkunde, vol. 84, pp. 662-667, 1993.

[229] G. Grube, "On the alloys of magnesium with tin and thallium," Zeitschrift Fur Anorganische Chemie, vol. 46, pp. 76-84, 1905.

[230] N. S. Kurnakow and N. J. Stepanow, "On the alloys of magnesium with tin and thallium," Zeitschrift Fur Anorganische Chemie, vol. 46, pp. 177-192, 1905.

[231] W. Hume-Rothery, "The system magnesium-tin and the compound Mg4Sn2," Journal of the Institute of Metals, vol. 35, pp. 336-347, 1926.

[232] G. V. Raynor, “The constitution of the magnesium-rich alloys in the systems magnesium-lead, magnesium-tin, magnesiumgermanium, and magnesium-silicon," Journal of the Institute of Metals, vol. 6, pp. 403-426, 1940.

[233] A. K. Nayak and W. Oelsen, "Thermal analysis of Mg-Sn alloys by calorimetric measurements for determination of the liquidus curve part 1," Transactions on Indian Institute of Metals, pp. 1520, 1968.

[234] A. K. Nayak and W. Oelsen, "Quatitative thermal analysis of magnesium-tin alloys by calorimetric measurement for the determination of solidus and liquidus curves," Transactions on Indian Institute of Metals, pp. 53-58, 1969.

[235] A. Steiner, E. Miller, and K. L. Komarek, "Magnesium-tin phase diagram and thermodynamic properties of liquid magnesiumtin alloys," Transactions of Metals Society AIME, vol. 230, pp. 1361-1367, 1964.

[236] P. Beardmore, B. W. Howlett, B. D. Lichter, and M. B. Bever, "Thermodynamic properties of compounds of magnesium and group IVB elements," Transactions of Metals Society AIME, vol. 236, pp. 102-108, 1966.

[237] C. T. Heycock and F. H. Neville, "XXVII.-The molecular weights of metals when in solution," Journal of the Chemical Society, Transactions, vol. 57, pp. 376-393, 1890.

[238] J. Ellmer, K. E. Hall, R. W. Kamphefner, J. T. Pfeifer, V. Stamboni, and C. D. Graham Jr., "On the liquidus in tin-rich $\mathrm{Sn}-\mathrm{Mg}$ alloys," Metallurgical Transactions, vol. 4, no. 3, pp. 889-891, 1973.

[239] A. A. Nayeb-Hashemi and J. B. Clark, Phase Diagram of Binary Magnesium Alloys, ASM International, Materials Park, Ohio, USA, 1988.

[240] G. Grube and H. Vosskuhler, "Electrical conductivity and binary alloys phase diagram," Zeitschrift Electrochemistry, vol. 40, pp. 566-570, 1934.

[241] H. Vosskuhler, "Solubility of tin in magnesium," Metallwirtscaft, vol. 20, pp. 805-808, 1941.

[242] N. J. Stepanow, "Über die elektrische Leitfähigkeit der Metallegierungen," Zeitschrift fur Anorganische Chemie, vol. 78, pp. $1-32,1912$.

[243] J. A. Gann, "Treatment and structure of magnesium alloys," Transactions of the Metals Society AIME, vol. 83, pp. 309-332, 1929.

[244] H. Nishinura and K. Tanaka, "Age hardening of magnesiumrich magnesium-aluminum-tin alloys," Transactions of the Institution of Mining and Metallurgy Alumni Assocication, vol. 10, pp. 343-350, 1940.
[245] J. M. Eldridge, E. Miller, and K. L. Komarek, "Thermodynamic properties of liquid magnesium-silicon alloys, discussion of the Mg-Group IVB systems," Transactions of the Metals Society AIME, vol. 239, pp. 775-781, 1967.

[246] H. J. Caulfield and D. E. Hudson, "Sublimation in the intermetallic series $\mathrm{Mg}_{2} \mathrm{Si}, \mathrm{Mg}_{2} \mathrm{Ge}, \mathrm{Mg}_{2} \mathrm{Sn}$ and $\mathrm{Mg}_{2} \mathrm{~Pb}$," Solid State Communications, vol. 4, no. 6, pp. 299-301, 1966.

[247] A. K. Nayak and W. Oelsen, "Thermodynamic analysis of magnesium-tin alloys," Transaction of the Indian Institute of Metals, vol. 24, no. 2, pp. 22-28, 1971.

[248] V. N. Eremenko and G. M. Lukashenko, “Thermodynamic properties of Mg-Pb system," Ukrainskii Khimicheskii Zhurnal, vol. 29, pp. 896-900, 1963.

[249] O. Kubaschewski and A. Walter-Stuttgart, "Results of investigations of alloys by high-temperature calorimetry?" Zeitschrift Für Elektrochemie, vol. 45, pp. 732-740, 1939.

[250] W. Biltz and W. Holverscheit, "Systematic affinity principle XLVII, the relation of mercury to a few metals," Zeitschrift fur Anorganische Chemie, vol. 176, p. 23, 1928.

[251] S. Ashtakala and L. M. Pidgeon, "Determination of the activities of magnesium in liquid magnesium-tin alloys by vapor pressure measurements," Canadian Journal of Chemistry, vol. 40, pp. 718$728,1962$.

[252] F. J. Jelinek, W. D. Shickell, and B. C. Gerstein, “Thermal study of group II-IV semiconductors, II. Heat capacity of $\mathrm{Mg} 2 \mathrm{Sn}$ in the range 5-300 K," Journal of Physics and Chemistry of Solids, vol. 28, no. 2, pp. 267-270, 1967.

[253] H. Y. Chen, N. Savvides, T. Dasgupta, C. Stiewe, and E. Mueller, "Electronic and thermal transport properties of Mg2Sn crystals containing finely dispersed eutectic structures," Physica Status Solidi A, vol. 207, no. 11, pp. 2523-2531, 2010.

[254] J. J. Egan, "Thermodynamics of liquid magnesium alloys using CaF2 solid electrolytes," Journal of Nuclear Materials, vol. 51, no. 1, pp. 30-35, 1974.

[255] C. A. Eckert, J. S. Smith, R. B. Irwin, and K. R. Cox, "A chemical theory for the thermodynamics of highly-solvated liquid metal mixtures," AIChE Journal, vol. 28, no. 2, pp. 325-332, 1982.

[256] L. M. Pavlova and K. B. Poyarkov, "Nature of the dissociation of Mg stannide and thermodynamic properties of Mg-Sn melts," Zhurnal Fizicheskoi Khimii, vol. 56, pp. 295-299, 1982.

[257] I.-H. Jung and J. Kim, "Thermodynamic modeling of the Mg$\mathrm{Ge}-\mathrm{Si}, \mathrm{Mg}-\mathrm{Ge}-\mathrm{Sn}, \mathrm{Mg}-\mathrm{Pb}-\mathrm{Si}$ and $\mathrm{Mg}-\mathrm{Pb}-\mathrm{Sn}$ systems," Journal of Alloys and Compounds, vol. 494, no. 1-2, pp. 137-147, 2010.

[258] F. G. Meng, J. Wang, L. B. Liu, and Z. P. Jin, "Thermodynamic modeling of the Mg-Sn-Zn ternary system," Journal of Alloys and Compounds, vol. 508, no. 2, pp. 570-581, 2010.

[259] Y.-B. Kang and A. D. Pelton, "Modeling short-range ordering in liquids: the Mg-Al-Sn system," Calphad, vol. 34, no. 2, pp. 180$188,2010$. 

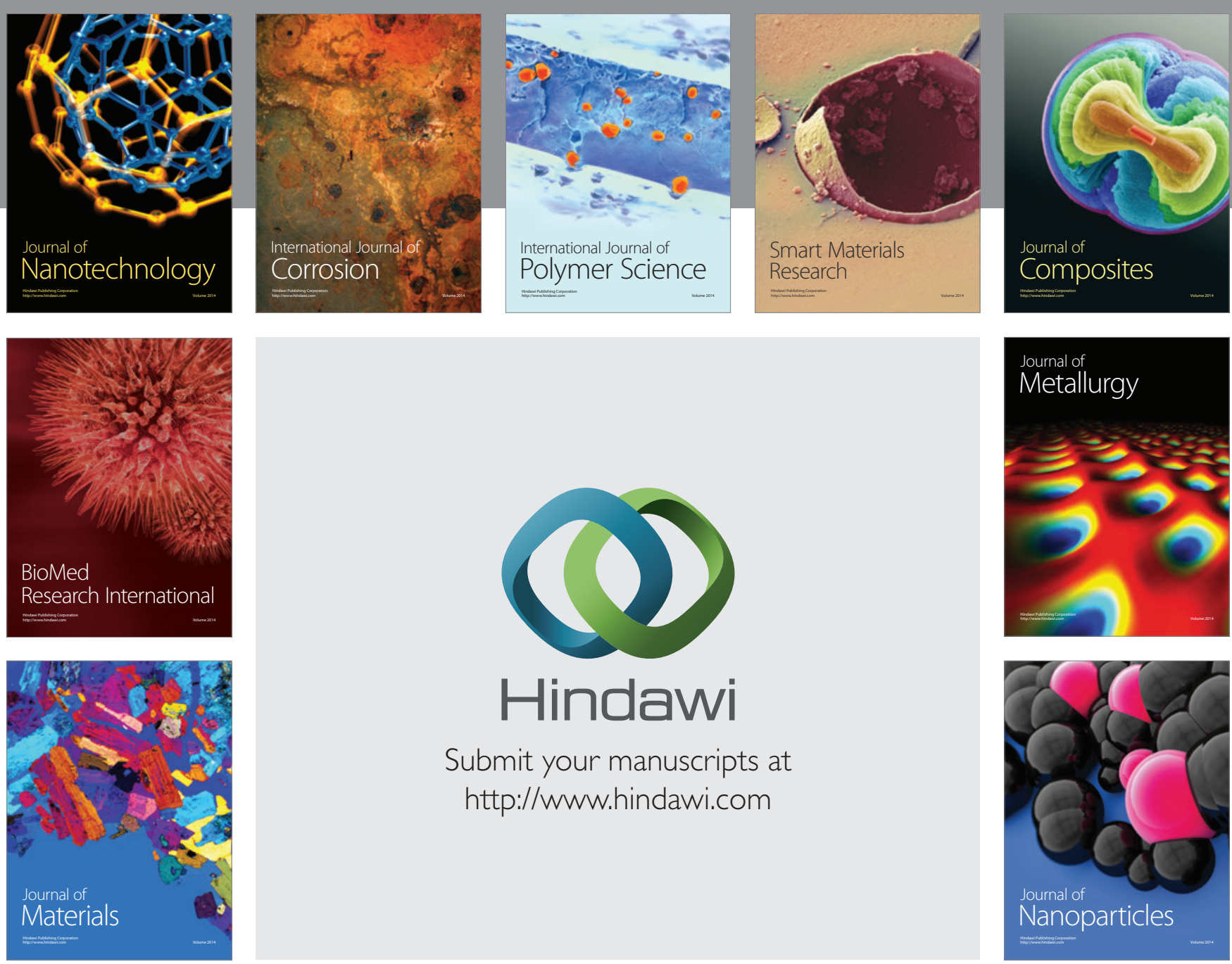

Submit your manuscripts at http://www.hindawi.com


\section{The Scientific World Journal}
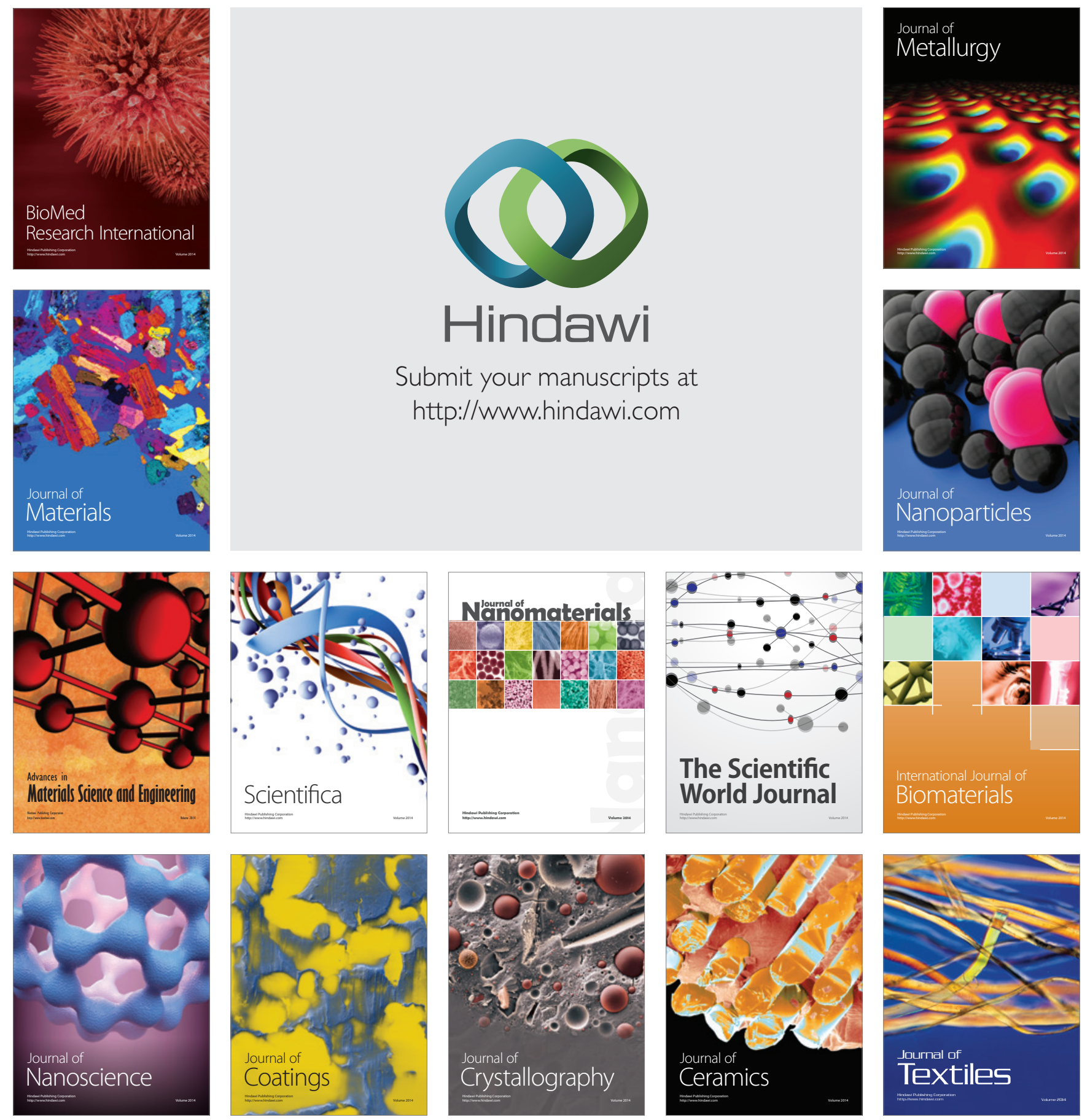